\title{
Studies on adaptor proteins that shape antigen receptor-proximal signal transduction in B lymphocytes
}

\author{
Doctoral Thesis \\ In partial fulfillment of the requirements for the degree \\ "Doctor rerum naturalium (Dr. rer. nat.)" \\ in the Molecular Medicine Study Program \\ at the Georg-August University Göttingen \\ submitted by \\ Marion Lösing \\ born in \\ Vreden
}




\section{Members of the thesis committee:}

Supervisor:

Prof. Dr. Jürgen Wienands

Department of Cellular and Molecular Immunology, University Medicine Göttingen

Second member of the thesis committee:

Prof. Dr. Tomas Pieler

Department of Developmental Biochemistry, Georg-August University Göttingen

Third member of the thesis committee:

Prof. Dr. Dieter Kube

Department of Haematology and Oncology, University Medicine Göttingen

\section{Date of Disputation:}




\section{Affidavit}

Here I declare that my doctoral thesis entitled "Studies on adaptor proteins that shape antigen receptor-proximal signal transduction in B lymphocytes" has been written independently with no other sources and aids than quoted. This thesis (wholly or in part) has not been submitted elsewhere for any academic award or qualification.

Marion Lösing

Göttingen, March 2011 
So eine Arbeit wird eigentlich nie fertig, man muss sie für fertig erklären, wenn man nach der Zeit und den Umständen das Möglichste getan hat.

J.W. von Goethe 1749-1832 


\section{Danksagung}

Ich danke meinem Doktorvater, Herrn Prof. Dr. Jürgen Wienands, für das in mich gesetzte Vertrauen in den vergangenen Jahren. Seine Diskussionsbereitschaft und sein fachlicher Rat haben großen Anteil am Gelingen dieser Arbeit gehabt.

Prof. Dr. Tomas Pieler und Prof. Dr. Dieter Kube danke ich für ihre Bereitschaft mich über die Jahre als, thesis committee' zu begleiten und zu beraten.

Besonderer Dank geht an Michael. Ohne seine praktische, theoretische und moralische Unterstützung wäre diese Arbeit nicht in dieser Form entstanden. Ich weiß, dass ich dich trotz umfangreicher Versorgung mit Nervennahrung einiger dieser Exemplare gekostet habe, vor allem in den letzten Monaten. Danke für deine Hilfsbereitschaft.

Meinen aktuellen und ehemaligen Kollegen aus der Immunologie danke ich für ihre Unterstützung im Laboralltag während vier langer Jahre, die man nur schwer in Worte fassen kann. Vor allem Kai, Johannes und Tobi haben dafür gesorgt, dass ich auch immer wieder ausgiebig zu lachen hatte.

Ein besonderer Dank geht an Birgit für ihre fachliche und moralische Unterstützung sowie für ihre unermüdliche Ausdauer, sich meine Leiden anzuhören

Ein großes Dankeschön auch an Ines. Nicht nur deine experimentelle Unterstützung hat großen Anteil an der Entstehung dieser Arbeit.

Nadine danke ich für das Korrekturlesen dieser Arbeit und für manch mahnendes Wort, aber vor allem für ein offenes Ohr.

Allen Freunden in und um Göttingen danke ich für ihr Verständnis und ihren moralischen Rückhalt, allen voran Christiane und Christian.

Ein ganz großes Dankeschön geht an meine Mädels Waja und Franzi. Fast neun Jahre sind wir zusammen durch dick und dünn gegangen. Ich werde diese Zeit nie vergessen und euch beiden einen besonderen Platz in meinem Herzen einräumen.

Heimat wird erst richtig zur Heimat durch einen Haufen guter Freunde. Danke auch an Anne W., Tina G., Martina, Marlena, Ramona, Kathrin, Rainer, Tina T., Anne H., Charlotte, Sarah, Maria, Michi, Mareen, Britta und Ina. Besonderer Dank auch an Sarah S. und die ,Deutsche Post'.

Meiner gesamten Familie, insbesondere meinen Geschwistern Sabrina und Markus, danke ich für ihren Rückhalt und ihre Unterstützung.

Danke Marco, einfach dafür das du da bist.

Goethe sagte einst: „Zwei Dinge sollen Kinder von ihren Eltern bekommen: Wurzeln und Flügel. "Aus tiefstem Herzen danke ich meinen Eltern, Hedwig und Hermann, für kräftige Wurzeln und viele Federn um meine Flügel auszubreiten. Ohne eure vorbehaltlose Unterstützung wäre ich nicht soweit gekommen. 


\section{Contents}

Contents......

List of Figures.............................................. V

List of Tables.................................................. VI

Abbreviations.................................................................... VII

$1 \quad$ Abstract................................................................ 1

$2 \quad$ Introduction........................................................... 2

2.1 Structure, function and development of antigen receptors on B

lymphocytes............................................ 2

2.2 Antigen receptor-induced signaling in B lymphocytes................ 4

2.3 Consequences of deregulated BCR signaling ...................... 7

2.4 Modulation of BCR-mediated signaling processes.................. 10

2.4.1 The adaptor protein Grb2 is a key regulator of BCR 10

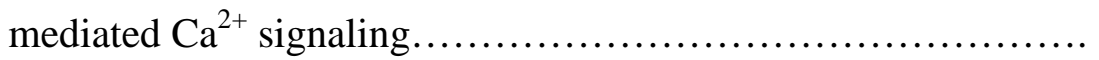

2.4.2 The Dok adaptor proteins............................... 12

2.4.2.1 Dok proteins in immunoreceptor signaling........................ 12

$3 \quad$ Aims of the work......................................................... 16

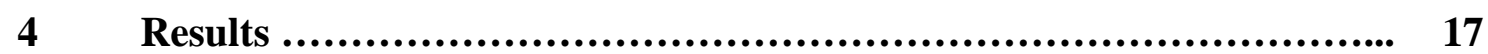

4.1 Grb2 mediates the redistribution of Dok-3 into microsignalosomes.... 17

4.1.1 Microsignalosomal abundance of Dok-3 is approved by an association of Grb2 and the microsignalosome resident Lyn......

4.1.2 Relocalization of Dok-3/Grb2 to microsignalosomes is depending on Vav3 and SLP-65.......................... 19

4.1.3 Providing microsignalosome abundance of Dok-3 is not the only function of the C-terminal SH3 domain of Grb2.

4.2 The Dok-3/Grb2 complex modulates the Lyn-dependent phosphorylation of BCR signaling effectors.

4.2.1 The Dok-3/Grb2 complex regulates effector functions upstream 
of the $\mathrm{Ca}^{2+}$ initiation complex. 26

4.2.1.1 The Dok-3/Grb2 complex still inhibits BCR-induced

$\mathrm{Ca}^{2+}$ mobilization when Btk is absent from the $\mathrm{Ca}^{2+}$ initiation complex. 26

4.2.1.2 Dok-3/Grb2 decrease the BCR-induced SLP-65 phosphorylation.

4.2.2 Dok-3 expression decreases the BCR-induced Syk activation..... 28

4.2.2.1 Dok-3 attenuates BCR-induced phosphorylation of Syk.... 28

4.2.2.2 The Dok-3/Grb2 complex alters BCR-induced Syk phosphorylation in a site-specific manner.

4.2.2.3 The Dok-3/Grb2 complex reduces the kinase activity of Syk.

4.2.2.4 Dok-3/Grb2 attenuates Lyn-dependent Syk phosphorylation.

4.2.3 Dok-3/Grb2 alters the phosphorylation pattern of inhibitory Lyn targets

4.2.3.1 The BCR-induced phosphorylation of SHIP is augmented by Dok-3.

4.2.3.2 Dok-3 does not alter the BCR-induced SHP-1

phosphorylation.

4.2.3.3 Dok-3 promotes the BCR-induced phosphorylation of SHP-2 38

4.2.3.4 The BCR-induced phosphorylation of $\mathrm{c}-\mathrm{Cbl}$ is not altered by Dok-3....

4.2.4 Lyn is required for the Dok-3/Grb2 dependent signal inhibition...

4.2.4.1 The BCR-induced Lyn-phosphorylation is not altered by Dok-3/Grb2 ......................................

4.2.4.2 Dok-3/Grb2 does not influence the Lyn kinase activity...... 42

4.2.4.3 Dok-3/Grb2 mediated negative regulation is depending on Lyn

Discussion.

5.1 Association of Grb2 and Dok-3 translocates this protein complex into BCR microsignalosomes 
5.2 Dok-3-associated Grb2 contributes to negative regulation of BCR signals in BCR microsignalosomes............................. 51

5.3 Dok-3/Grb2 accentuates the negative regulatory functions of Lyn..... 51

Summary.................................................................................. 57

$6.1 \quad$ Zusammenfassung.......................................... 58

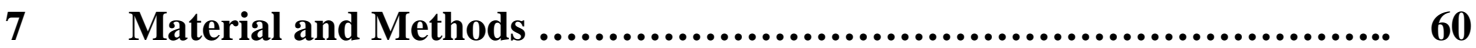

7.1 Materials.................................................... 60

7.1.1 Antibodies............................................... 60

7.1 .2 Enzymes.............................................. 62

7.1 .3 Vectors................................................ 62

7.1.4 Oligonucleotides........................................ 63

7.1.5 Constructs................................................ 64

7.1.6 Biotinylated peptides.................................... 65

7.1.7 Bacterial strains......................................... 65

7.1.8 Cell lines................................................. 66

7.1.9 Solutions, buffers and media............................ 67

7.2 Additional Material.............................................. 67

7.3 Instruments................................................. 68

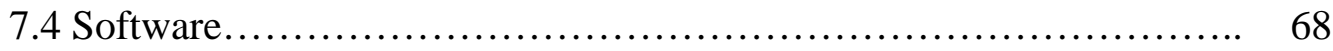

7.5 Experimental Procedure........................................ 69

7.5.1 Methods in molecular biology............................ 69

7.5.1.1 Generation of transformation competent E.coli bacteria..... 69

7.5.1.2 Transformation of competent E.coli bacteria.............. 69

7.5.1.3 Isolation of plasmid DNA......................... 70

7.5.1.4 Isolation of genomic DNA from tissue culture cells........ 70

7.5.1.5 Digestion of DNA with restriction endonucleases......... 70

7.5.1.6 Dephosphorylation of linearized DNA................. 71

7.5.1.7 Ethanol precipitation of linearized DNA................. 71

7.5.1.8 Ligation of DNA .................................. 71

7.5.1.9 Polymerase chain reaction (PCR) ..................... 71

7.5.1.10 T/A cloning................................... 73

7.5.1.11 Agarose gel electrophoresis....................... 73 
7.5.1.12 Isolation of DNA-Fragments from agarose gels.......... 74

7.5.1.13 DNA-Sequencing................................ 74

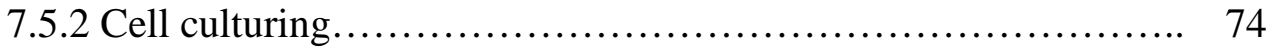

7.5.2.1 Cultivation of eukaryotic cells....................... 74

7.5.2.2 Thawing and freezing of cells........................ 75

7.5.2.3 Transfection of DT40 cells by electroporation............ 75

7.5.2.4 Transfection of Plat-E cells for production of recombinant viruses................................. 75

7.5.2.5 Transfection of DT40 cells with recombinant viruses....... 76

7.5.2.6 $\mathrm{Ca}^{2+}$ mobilization analysis............................ 77

7.5.2.7 Confocal laser scanning microscopy................... 77

7.5.3 Biochemical Methods................................. 78

7.5.3.1 Production of recombinant GST-Fusion proteins.......... 78

7.5.3.2 Stimulation of DT40 cells via the BCR ................ 78

7.5.3.3 Affinity purification experiments...................... 79

7.5.3.4 Affinity purification upon SILAC (Stable isotope labeling

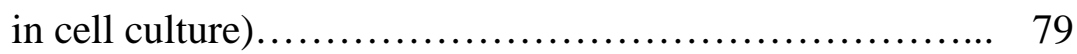

7.5.3.5 Immunoprecipitation experiments.................... 80

7.5.3.6 In vitro kinase assay.............................. 80

7.5.3.7 Intracellular FACS staining for Phosflow ${ }^{\mathrm{TM}}$ analysis....... 80

7.5.3.8 SDS polyacrylamide gel electrophoresis (SDS-PAGE)

(LAEMMLI, 1970)................................ 81

7.5.3.9 Coomassie Brilliant Blue (CBB) staining............... 81

7.5.3.10 Western blotting.................................. 82

7.5.3.11 Far Western........................................ 82

7.5.3.12 ELISA........................................... 83

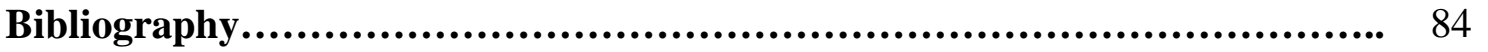

Curriculum Vitae............................................................ 102 


\section{List of Figures:}

Figure 2.1: Domain structure of signaling effectors and events downstream of BCR engagement.

Figure 2.2: Grb2: schematic overview of its structure and examples for binding partners.

Figure 2.3: Schematic overview of the structure and binding partners of avian Dok-3.

Figure 2.4: The alternative recruitment of $\mathrm{Grb} 2$ mediates inhibition of $\mathrm{Ca}^{2+}$ signaling

Figure 4.1: Grb2 is associated with Lyn in an indirect manner.

Figure 4.2: The BCR-induced phosphorylation of Dok-3 is impaired in DT40 cells lacking SLP-65- and Vav3-expression.

Figure 4.3: The BCR-induced Dok-3 phosphorylation is compromised in Vav3- and SLP-65-deficient cells

Figure 4.4: The association of Grb2 and Lyn is narrowed in cells deficient for Vav3 and SLP-65.

Figure 4.5: Grb2 contributes to the Dok-3-mediated negative regulation of BCR signals in BCR microsignalosomes............................ 24

Figure 4.6: Dok-3 still influences a Btk binding deficient SLP-65................ 26

Figure 4.7: Dok-3 expression leads to decreased BCR-induced SLP-65 phosphorylation.

Figure 4.8: $\quad$ Dok-3 expression leads to decreased BCR-induced Syk phosphorylation 28

Figure 4.9: Generation of $d o k-3 / s y k^{-/}$DT40 B cells............................ 30

Figure 4.10: $\quad \mathrm{Y}^{352}$ of Syk is less efficiently phosphorylated in Dok-3-expressing cells.. 31

Figure 4.11: Expression of Dok-3 decreases the phosphorylation efficiency of Syk $\mathrm{Y}^{352}$

Figure 4.12: $\quad$ Dok-3/Grb2 reduces the kinase activity of Syk in BCR-activated cells... 33

Figure 4.13: $\quad$ Generation of $l y n / d o k-3^{-/}$DT40 B cells............................... 34

Figure 4.14: Dok-3 does not alter the BCR-induced phosphorylation of Syk in absence of Lyn. 
Figure 4.15: Dok-3/Grb2 mediated inhibition is not restricted to alterations in Syk $\mathrm{Y}^{352}$ phosphorylation.......................................... 36

Figure 4.16: Dok-3 expression leads to an increase of SHIP phosphorylation......... 37

Figure 4.17: Dok-3 does not alter the BCR-induced SHP-1 phosphorylation.......... 38

Figure 4.18: The BCR-induced SHP-2 phosphorylation requires Dok-3............. 39

Figure 4.19: $\quad$ Dok-3/Grb2 does not alter BCR-induced Cbl phosphorylation........... 40

Figure 4.20: Dok-3/Grb2 does not significantly alter BCR-induced Lyn phosphorylation.................................................. 41

Figure 4.21: Dok-3 does not influence the kinase activity of Lyn................. 42

Figure 4.22: The 'Lyn-independent' chimeric Dok-3YYFF-cSH3 protein reconstitutes Dok-3/Grb2 mediated $\mathrm{Ca}^{2+}$ inhibition with reduced efficiency.................................................. 43

Figure 4.23: The 'Lyn-independent' chimeric Dok-3YYFF-cSH3 protein cannot form homo-oligomers......................................... 44

Figure 4.24: Expression of Lyn is obligatory for the inhibitory effect of the Dok-3/Grb2 chimera............................................ 45

Figure 5.1: Dok-3/Grb2 is translocated to the microsignalosomes by binding to Vav3 and/or SLP-65..........................................

Figure 5.2: The Dok-3/Grb2 alters the phosphorylation pattern of several Lyn substrates...................................................... 56 


\section{List of Tables:}

Table 7.1: $\quad$ Primary antibodies............................................ 60

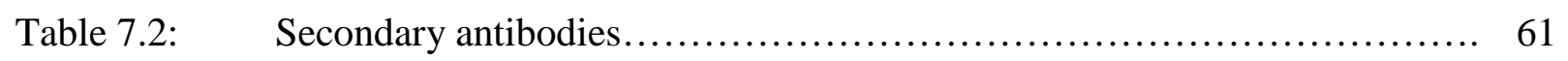

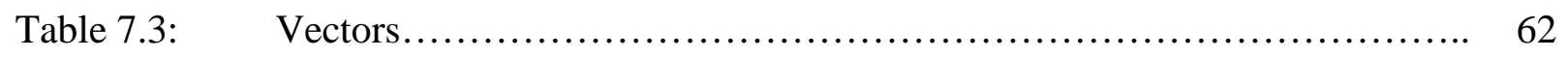

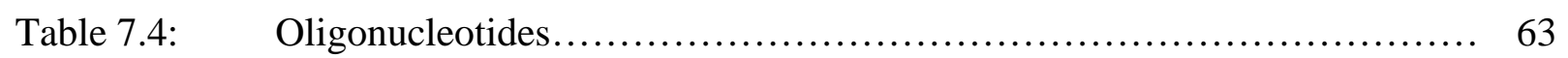

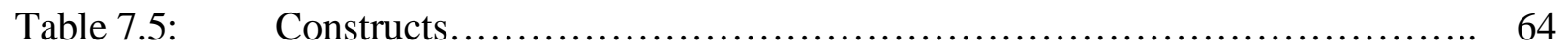

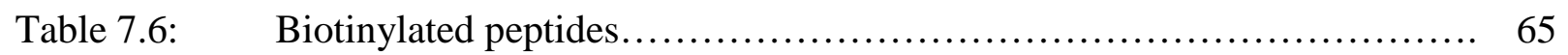

Table 7.7: $\quad$ Bacteria strains..................................................... 65

Table 7.8: $\quad$ DT40 knock-out cell lines..................................... 66

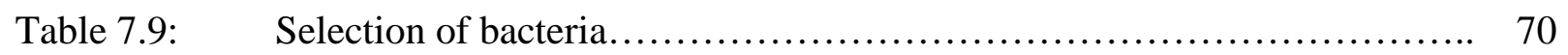

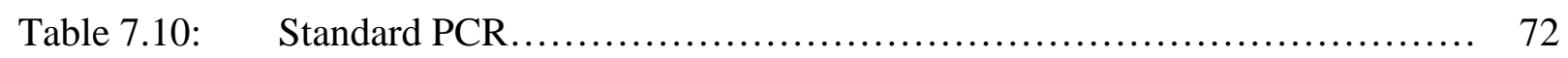

Table 7.11: $\quad$ Summary of cycling parameters................................. 72

Table 7.12: $\quad$ Selection of DT40................................................ 75 


\section{Abbreviations}

aa

$\mathrm{Ab}$

ABTS

Amp

AP

APS

ATCC

ATP

BASH

BCR

Bimp1

Bleo

Blk

BLNK

BM

$\mathrm{bp}$

BSA

Btk

$\mathrm{C} 2$

CARD11

CARMA1

$\mathrm{Cbl}$

CCL

cDNA

CDR

$\mathrm{ch}$

CIP

Cit

CNS

CRAC

CS amino acid

antibody

2,2'-azino-bis(3-ethylbenzthiazoline-6-sulphonic acid)

ampicillin

affinity purification

ammonium persulphate

American type culture collection

adenosine trisphosphate

B cell adaptor containing an $\mathrm{SH} 2$ domain

$\mathrm{B}$ cell antigen receptor

BcI10 Interacting MAGUK Proteins

Bleomycin

B cell lymphoma kinase

B cell linker protein

bone marrow

base pair

bovine serum albumin

Bruton's tyrosine kinase

conserved 2 domain

Caspase recruitment domain-containing protein 11

Caspase recruitment domain-containing membrane-associated guanylate kinase protein 1

Casitas B-lineage lymphoma

cleared cellular lysate

complementary DNA/ copy DNA

complementarity determining region

chicken

Calf intestine phosphatase

Citrin

Central nervous system

$\mathrm{Ca}^{2+}$ release activated $\mathrm{Ca}^{2+}$ channel

chicken serum 
Csk C-terminal Src kinase

$\Delta$

deletion

$\mathrm{Da}$

Dalton

DAG

diacylglycerol

DLBCL

Diffuse large B cell lymphoma

DMEM

Dulbecco's modified Eagle's medium

DMSO

DMSO dimethylsulfoxide

DNA

deoxyribonucleic acid

dNTP

2'-deoxynucleoside-5' -trisphosphate

Dok

Downstream of kinase

Dok-L

Dok-like

Dok-R

Dok-related

DTT

1,4-dithiothreitol

E. coli

Escherichia coli

ECL

Enhanced chemical luminescence

EDTA

ethylenediamine tetraacetic acid

EGTA

ethylene-glycol-bis(2-aminoethyl ether)-N,N,N',N'-tetraacetic acid

env

envelope; gene encoding glycoprotein 160

ER

endoplasmic reticulum

ERK

extracellular signal-regulated kinase

FACS

fluorescence-activated cell sorter

Fc

fragment crystalline

FcR

Fc receptor

FCS

fetal calf serum

Fyn

fgr/yes-related novel PTK

gag

gene encoding p55 (core protein)

GEF

guanine-nucleotide exchange factor

GFP

green fluorescent protein

gpt

Xanthine-guanine phosphoribosyl transferase

Grb2

growth factor receptor-bound protein 2

GST

glutathione-S-transferase

GTPase

guanosine trisphosphatase

HA

peptide from influenza hemagglutinin protein (YPYDVPDYA) 


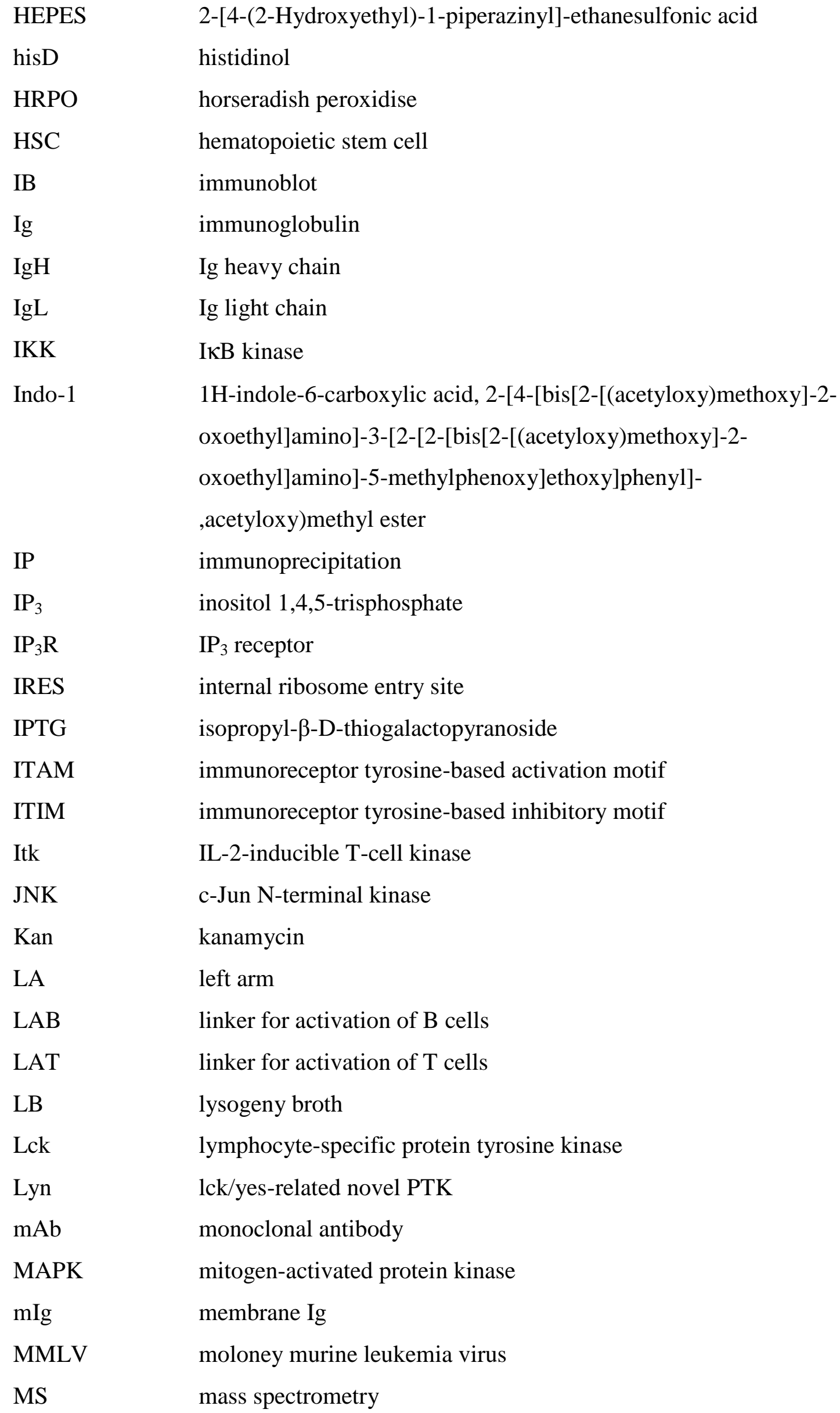


MS

NFAT

$\mathrm{NF}-\kappa \mathrm{B}$

NK cells

NP-40

NTAL

OD

$\mathrm{p}$

$\mathrm{P}$

PAGE

PBS

PCR

$\mathrm{PH}$ domain

PI3K

$\mathrm{PI}(3,4) \mathrm{P} 2$

$\mathrm{PI}(4,5) \mathrm{P} 2$

$\mathrm{PI}(3,4,5) \mathrm{P} 3$

PKC

PLC- $\gamma 2$

pol

PTB domain

PTK

PTP

pTyr

pY

RA

RA

Ras

RasGAP

RasGRP

Rho

RNA

rpm

RPMI multiple sclerosis

nuclear factor of activated $\mathrm{T}$ cells

nuclear factor for $\kappa$ gene in B lymphocytes

natural killer cells

nonident $\mathrm{p}-40$

non- $\mathrm{T}$ cell activation linker

optical density

protein

phosphate

polyacrylamide gel electrophoresis

phosphate-buffered saline

polymerase chain reaction

pleckstrin homology domain

phosphatidylinositol 3'-kinase

phosphatidylinositol 3,4-bisphosphate

phosphatidylinositol 4,5-bisphosphate

phosphatidylinositol 3,4,5-trisphosphate

protein kinase $\mathrm{C}$

phospholipase C- $\gamma 2$

gene encoding protease, reverse transcriptase, and integrase

phosphotyrosine binding domain

protein tyrosine kinase

protein tyrosine phosphatase

phosphotyrosine

phosphotyrosine

rheumatoid arthritis

right arm

abbreviation originated from rat sarcoma

Ras GTPase-activating protein

Ras guanine nucleotide releasing protein

Ras homology

ribonucleic acid

rounds per minute

Roswell Park Memorial Institute 


\begin{tabular}{|c|c|}
\hline RT & room temperature \\
\hline s.d. & standard deviation \\
\hline SDS & sodium dodecylsulfate \\
\hline Shc & SH2-containing sequence \\
\hline SH domain & Src homology domain \\
\hline SHIP & SH2 domain-containing inositol 5' -phosphatase \\
\hline SHP-1/2 & $\mathrm{SH} 2$ domain-containing protein tyrosine phosphatases $1 / 2$ \\
\hline SILAC & stable isotope labeling in cell culture \\
\hline SLE & Systemic lupus erythematosus \\
\hline SLP-65 & $\mathrm{SH} 2$ domain-containing leukocyte protein of $65 \mathrm{kDa}$ \\
\hline $\mathrm{SOC}$ & store-operated channel \\
\hline SOS & son of sevenless \\
\hline $\operatorname{src}$ & Rous sarcoma oncogene \\
\hline STIM & stromal interaction molecule \\
\hline Syk & Spleen tyrosine kinase \\
\hline $\mathrm{t}$ & time \\
\hline $\mathrm{T}$ & temperature \\
\hline TAE & Tris acetate EDTA buffer \\
\hline TBE & Tris borate EDTA buffer \\
\hline TBS & Tris-buffered saline \\
\hline TCR & $\mathrm{T}$ cell antigen receptor \\
\hline TD & thymus dependent \\
\hline Tec & Tyrosine kinase expressed in hepatocellular carcinoma \\
\hline TEMED & $\mathrm{N}, \mathrm{N}, \mathrm{N}^{\prime}, \mathrm{N}^{\prime}$-tetramethylethylene-diamine \\
\hline TI & thymus independent \\
\hline $\mathrm{Tm}$ & melting temperature \\
\hline Tris & Tris-(hydroxymethyl)-aminomethane \\
\hline Triton X-100 & 4-(2',2',4',4'-tetramethylbutyl)phenyldecaethylene-glycolether \\
\hline Tween-20 & polyoxyethylene sorbitan monolaurate \\
\hline $\mathrm{U}$ & Units \\
\hline UV & ultraviolet \\
\hline Vav & six (Hebrew); adapter protein with GEF activity \\
\hline VSV-G & vesicular stomatitis virus glycoprotein \\
\hline $\mathrm{v} / \mathrm{v}$ & volume per volume \\
\hline
\end{tabular}




$\begin{array}{ll}\text { w/o } & \text { without } \\ \text { w/v } & \text { weight per volume } \\ \text { wt } & \text { wild-type } \\ \text { X-Gal } & \text { 5-bromo-4-chloro-3-indoxyl- } \beta \text {-D-galactopyranoside } \\ \text { xid } & \text { x-coupled immunodeficiency } \\ \text { XLA } & \text { x-linked agammaglobulinaemia } \\ \text { ZAP-70 } & \text { zeta-chain associated protein of } 70 \mathrm{kDa}\end{array}$

II Amino Acids

\begin{tabular}{|c|c|c|}
\hline Amino Acid & 3-letter-code & symbol \\
\hline Alanine & Ala & $\bar{A}$ \\
\hline Cysteine & Cys & $\mathrm{C}$ \\
\hline Aspartic Acid & Asp & $\mathrm{D}$ \\
\hline Glutamic Acid & Glu & $\mathrm{E}$ \\
\hline Phenylalanine & Phe & $\mathrm{F}$ \\
\hline Glycine & Gly & G \\
\hline Histidine & His & $\mathrm{H}$ \\
\hline Isoleucine & Ile & $\mathrm{I}$ \\
\hline Lysine & Lys & $\mathrm{K}$ \\
\hline Leucine & Leu & $\mathrm{L}$ \\
\hline Methionine & Met & $\mathrm{M}$ \\
\hline Asparagine & Asn & $\mathrm{N}$ \\
\hline Proline & Pro & $\mathrm{P}$ \\
\hline Glutamine & Gln & Q \\
\hline Arginine & Arg & $\mathrm{R}$ \\
\hline Serine & Ser & $\mathrm{S}$ \\
\hline Threonine & Thr & $\mathrm{T}$ \\
\hline Valine & Val & $\mathrm{V}$ \\
\hline Tryptophan & $\operatorname{Trp}$ & $\mathrm{W}$ \\
\hline Tyrosine & Tyr & $\mathrm{Y}$ \\
\hline
\end{tabular}


III Deoxyribonucleotides

\begin{tabular}{|l|c|}
\hline \multicolumn{1}{|c|}{ Deoxyribonucleotides } & symbol \\
\hline deoxyadenosine monophosphate & $\mathrm{a}, \mathrm{A}$ \\
\hline deoxycytidine monophosphate & $\mathrm{c}, \mathrm{C}$ \\
\hline deoxyguanosine monophospate & $\mathrm{g}, \mathrm{G}$ \\
\hline deoxythymidine monophosphate & $\mathrm{t}, \mathrm{T}$ \\
\hline
\end{tabular}

IV Prefixes and Units

$\begin{array}{llllll}\mathrm{M} & \text { mega } & \mathrm{m} & \text { meter } & \mathrm{V} & \text { volt } \\ \mathrm{k} & \text { kilo } & \mathrm{L} & \text { liter } & \mathrm{A} & \text { ampere } \\ \mathrm{c} & \text { centi } & \mathrm{M} & \text { molar } & \mathrm{F} & \text { farad } \\ \mathrm{m} & \text { milli } & \mathrm{g} & \text { gram } & \mathrm{h} & \text { hour } \\ \mu & \text { micro } & \mathrm{b} & \text { base } & \mathrm{min} & \text { minute } \\ \mathrm{n} & \text { nano } & \mathrm{bp} & \text { base-pair } & \mathrm{s} & \text { second } \\ \mathrm{p} & \text { pico } & \mathrm{Da} & \text { Dalton } & \mathrm{U} & \text { unit } \\ & & { }^{\circ} \mathrm{C} & \text { degree Celsius } & & \\ & & g & \text { acceleration of gravity } & & \end{array}$




\section{Abstract}

Signals that are transduced by the $\mathrm{B}$ cell antigen receptor (BCR) control B cell development and activation. Engagement of the BCR initiates the assembly and activation of the antigen receptor-specific $\mathrm{Ca}^{2+}$ initiation complex which triggers the transient release of $\mathrm{Ca}^{2+}$ from intra- and extracellular stores. The profile of the $\mathrm{Ca}^{2+}$ signal differs amongst developmental B cell stages and is thought to control distinct cellular responses like proliferation and apoptosis. Hence, regulation of $\mathrm{BCR}$-induced $\mathrm{Ca}^{2+}$ mobilization is important to keep the balance between humoral immunity and tolerance. An important regulator of differential $\mathrm{Ca}^{2+}$ mobilization is the adaptor protein Dok-3. Lyn-dependent complex formation with Grb2 is essential to attenuate the efficiency of $\mathrm{Ca}^{2+}$ mobilizing enzymes. By combining genetic, biochemical and real time imaging approaches this work elucidates the molecular mechanisms underlying the association of Dok-3 and Grb2. It could be shown that the Dok-2/Grb2 complex is translocated into microsignalosomes upon BCR-engagement. Furthermore, molecular details of this process and two potential binding partners required for the translocation of Dok-3/Grb2 have been elucidated. Once residing in the microsignalosomes the data unveil that, although not influencing the phosphorylation or activity of Lyn, Dok-3/Grb2 directly orchestrates the phosphorylation pattern of Lyn targets. Whereas the phosphorylation and activity of $\mathrm{Ca}^{2+}$ mobilizing enzymes are suppressed by Dok-3/Grb2, regulatory proteins become stronger phosphorylated. Based on these results we propose that Dok-3 modulates the balance of activatory and inhibitory Lyn functions by shaping the composition of BCR microsignalosomes. 


\section{Introduction}

Cells mediating immune responses originate from pluripotent hematopoietic stem cells (HSCs) in the bone marrow (BM) (WEISSMANN, 2000). These leukocytes encompass cells from the myeloid lineage and the lymphoid lineage. The myeloid lineage includes granulocytes, macrophages, dendritic cells and mast cells and participates in both, innate and adaptive immunity. The lymphoid lineage comprises B lymphocytes (B cells), $\mathrm{T}$ lymphocytes ( $\mathrm{T}$ cells), and natural killer (NK) cells. While the latter are ascribed to belong to the innate immunity, $\mathrm{B}$ and $\mathrm{T}$ cells provide adaptive immunity. $\mathrm{B}$ cells mature in the bone marrow whereas $\mathrm{T}$ cells mature in the thymus. $\mathrm{B}$ and $\mathrm{T}$ Lymphocytes form the basis of the adaptive immunity. They specifically recognize antigens by a vast repertoire of antigen receptors.

\subsection{Structure, function and development of antigen receptors on B lymphocytes}

The $\mathrm{B}$ cell antigen receptor (BCR) is a multiprotein complex comprising an antigenbinding membrane-bound immunoglobulin $(\mathrm{mIg})$ of different classes associated with two transmembrane proteins, Ig- $\alpha(\mathrm{CD} 79 \mathrm{a})$ and Ig- $\beta$ (CD79b). The mIg recognizes and binds extracellular antigens whereas $\operatorname{Ig}-\alpha$ and $-\beta$ are responsible for the signal transduction (RETH et al., 1991; RETH, 1992; NEUBERGER et al., 1993). Membrane-bound Ig's are tetrameric proteins consisting of two heavy chains and two light chains which are linked via disulfide bonds. The interplay of the complementarity-determining regions (CDR) of the heavy- and light-chain shape the antigen-binding region (RETH, 1992, WIENANDS, 2000a) and each individual B cell carries BCR of a single antigen specifity. There are five different classes of immunglobulines ( $\operatorname{IgM}, \operatorname{IgD}, \operatorname{IgG}, \operatorname{IgE}$ and $\operatorname{Ig} \mathrm{A}$ ) due to the isotype of their constant region. These regions differ from each other by their amount of Ig-domains, their amount of glycosylation and the composition of their cytoplasmic tail. The signal transducing units Ig- $\alpha$ and Ig- $\beta$ exhibit an extracellular Ig-like domain, a $\alpha$-helical transmembrane region and a cytoplasmic tail of 61 or 48 amino acids, respectively. The cytoplasmic tail inherits the immunoreceptor tyrosine-based activation motif (ITAM) (SANCHEZ et al., 1993, FLASWINKEL and RETH, 1994; TADDIE et al., 1994; CAMPBELL, 1995). One Ig- $\alpha$ is disulphid-linked to one Ig- $\beta$ and only when noncovalently associated with the mIg this complex functions as signal transferring unit (CAMPBELL and CAMBIER, 1990; HOMBACH et al., 1990; WIENANDS, 2000; SCHAMEL and RETH, 2000). 
Signals mediated through the BCR are fundamental for the development of B cells. B cell maturation in the bone marrow depends on nonlymphoid stromal cells. They form specific adhesive contacts with the cells and provide soluble factors that control lymphocyte differentiation and proliferation (SUDA et al., 2005; ZHANG and LI, 2008). The earliest B cell precursors are the pro-B cells. During this developmental stage the rearrangement of the heavy (H)-chain genes takes place (GRAWUNDER et al., 1998; GELLERT, 2002). After successful rearrangement the cells start synthesizing these heavy chains and are thus termed as pre-B cells. Small amounts of the heavy chain associate with the surrogate light chain (VpreB and $\lambda 5$ chains) and the Ig- $\alpha /-\beta$ heterodimer to form the pre-BCR expressed on the surface (KARASUYAMA et al., 1996; MARTENSSON et al., 2007). These are the first cells expressing a 'BCR' and signals through this pre-BCR are essential for the survival and differentiation of pre-B cells and those that fail to resemble the pre-BCR are deleted (HERZOG et al., 2009). Following receptor complex assembly pre-B cells endure several rounds of cell division (clonal expansion). Pre-BCR signaling is not only responsible for the survival of the pre-B cells but also is required for initiating the rearrangement of the light-chain gene leading to the expression of the BCR (compromised of two heavy and two light chains) and marking the step from pre-B cells to immature B cells (HERZOG et al., 2009). BCR-expression is mandatory for B cell development and survival in the periphery (LAM et al., 1997).

Immature B cells are checked for self reactivity before they are allowed to leave the BM. The cells that bind to antigen in the BM can undergo clonal deletion (apoptosis or negative selection), anergy or receptor editing (MANJARREZ-ORDUNO et al., 2009) whereas the cell fate decision depends on the strength of the BCR signals. This process is referred to as central tolerance (GOODNOW et al., 1999). Once immature B cells leave the BM they have to go through further transition processes during which low-level BCR signaling is required to inhibit apoptosis and to promote cell survival, while excessive BCR stimulation leads to cell death (WANG et al., 2007). Immature B cells then traffic to the spleen to undergo final maturation processes. These immature splenic cells, termed as transitional B cells, are based on their phenotype divided into T1- and T2-transitional B cells (LODER et al., 1999). T1-transitional B cells that detect antigens are trapped in the spleen and undergo apoptosis upon antigen recognition (WANG et al., 2007). T1 B cells which survive negative selection continue to mature into T2-transitional B cells which in turn complete B cell development as mature naïve B cells. 
Taken together, signals from the pre-BCR and the BCR are required for the progression of B cell development and the maintenance of B cell survival.

\subsection{Antigen receptor-induced signaling in B lymphocytes}

In resting $\mathrm{B}$ cells most $\mathrm{BCR}$ are freely diffusing within the plasma membrane. Binding of multivalent ligands to the BCR reduces their mobility and leads to the formation of BCR microsluster (DEPOIL et al., 2008). This process of BCR engagement activates Src family kinases (lck/yes-related novel kinase, Lyn; frg/yes-related novel PTK, Fyn; B cell lymphoma kinase, Blk). The Src family kinases are, due to their palmitoylation and myristoylation sites, constitutively residing in lipid rafts and are abundant at sites of BCR microcluster. In vitro studies show that Lyn and Fyn are in close association with the unligated, resting BCR (YAMANASHI et al., 1991; CAMPBELL and SEFTON, 1992; PLEIMAN et al., 1994).

Activated Src kinases phosphorylate the ITAM's of Ig- $\alpha$ and Ig- $\beta$ thus providing docking sites for the N-terminal tandem-Src homology 2 (SH2) domain of the cytosolic spleen tyrosine kinase (Syk) (KUROSAKI et al., 1995; WIENANDS et al., 1995; FUTTERER et al., 1998; PAO et al., 1998; SADA et al., 2001). Binding to the phosphorylated ITAM translocates Syk to the plasma membrane. Subsequent activation of the kinase results from a combination of Lyn-mediated phosphorylation, auto- and trans-phosphorylation and a break of allosterical inhibitory intramolecular interactions induced by the $\mathrm{SH} 2$-mediated recruitment to Ig- $\alpha /-\beta$ (KUROSAKI et al., 1994; KUROSAKI et al., 1995; KIMURA et al., 1996, DEINDL et al., 2007; TSANG et al., 2008).

Once activated, Syk phosphorylates the adaptor protein SLP-65 (SH2 domain-containing leukocyte protein of $65 \mathrm{kDa}$ ) also known as BLNK (B cell linker) or BASH (B cell adaptor containing an SH2 domain) (FU et al., 1998; GOITSUKA et al., 1998; WIENANDS et al., 1998). SLP-65 encompasses an N-terminal leucine zipper followed by a central region containing five highly conserved tyrosine phosphorylation sites and several proline rich regions (PRR), and a $\mathrm{C}$-terminal $\mathrm{SH} 2$ domain and is the central adaptor protein in the formation of protein complexes involved in several signaling processes.

One of these complexes, the so called $\mathrm{Ca}^{2+}$ initiation complex, is formed by the binding of the SH2 domains of the Tec family kinase Btk (Bruton's tyrosine kinase) and the phospholipase C- $\gamma 2$ (PLC- $\gamma 2$ ) to phosphorylated SLP-65 (KUROSAKI and TSUKADA, 2000). Only in context of this ternary complex Btk becomes phosphorylated and activated by Syk (KUROSAKI and KUROSAKI, 1997; BABA et al., 2001) and Lyn (MAHAJAN et 
al., 1995; RAWLINGS et al., 1995). Btk and Lyn phosphorylate and activate PLC- $\gamma 2$, which then triggers the hydrolysis of phosphatidyl-inositol-4,5-bisphosphate $\left(\mathrm{PI}(4,5) \mathrm{P}_{2}\right)$ into the second messengers diacylglycerol (DAG) and Inositol-1,4,5-trisphosphate $\left(\mathrm{IP}_{3}\right)$ (TAKATA and KUROSAKI, 1996; FLUCKIGER et al., 1998; HASHIMOTO et al., 2000; HUMPHRIES et al., 2004; KIM et al., 2004).

A
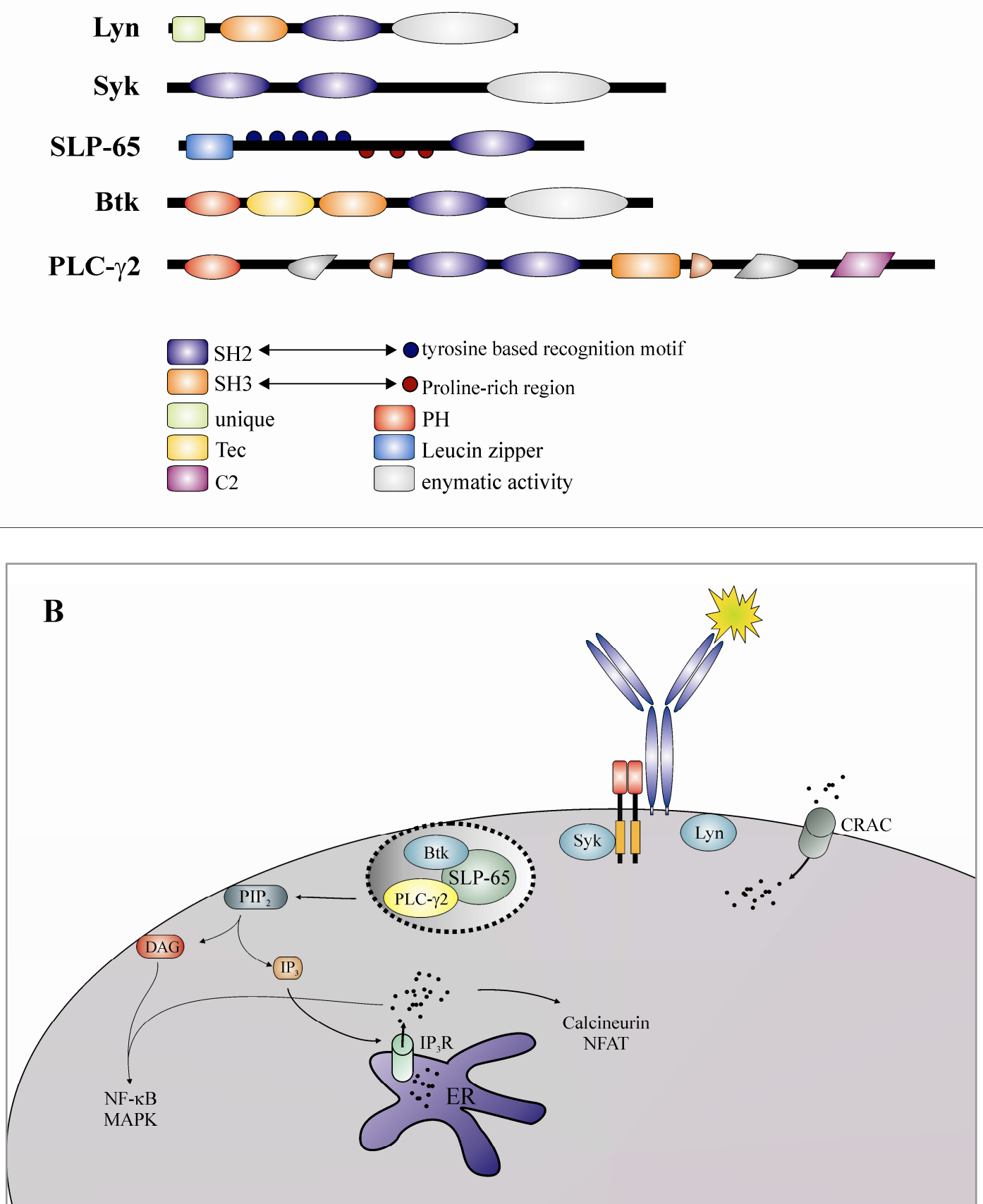

Figure 2.1 (legend see next page) 
Figure 2.1: Domain structure of signaling effectors and events downstream of BCR engagement.

(A) Domain structure of the central effectors of BCR mediated $\mathrm{Ca}^{2+}$ signaling: Lyn (lck/yes-related novel tyrosine kinase), Syk (spleen tyrosine kinase), SLP-65 (SH2 domain-containing leukocyte protein of $65 \mathrm{kDa}$ ), Btk (Bruton's tyrosine kinase) and PLC- $\gamma 2$ (phospholipase C- $\gamma 2$ ). Src homology 2 (SH2) domains bind to phosphorylated tyrosines (blue dots), Src homology 3 (SH3) domains bind to proline-rich regions (PRR) (red dots) and pleckstrin homology (PH) domains associate with phospholipids (modified from KUROSAKI, 2002). (B) After stimulation of the cell via the BCR protein tyrosine kinases like Lyn phosphorylate the immunoreceptor tyrosine-based activation motifs (ITAM, orange) of Ig $\alpha / \beta$. Phosphorylated ITAMs provide docking sites for the spleen tyrosine kinase (Syk). Syk phosphorylates the adaptor protein SLP-65 which then assembles the $\mathrm{Ca}^{2+}$ initiation complex (grey) by recruiting Btk and PLC- $\gamma 2$. Activated PLC- $\gamma 2$ hydrolyzes phosphatidylinositol$(4,5)$-bisphosphate $\left(\mathrm{PIP}_{2}\right)$ revealing the second messenger diacyglycerol (DAG) and inositol-(1,4,5)trisphosphate $\left(\mathrm{IP}_{3}\right)$.

DAG is a membrane associated second messenger responsible for the plasma membrane recruitment of the protein kinase $\mathrm{C}(\mathrm{PKC})-\beta$. Fully activation of PKC- $\beta$ requires the binding of $\mathrm{Ca}^{2+}$ to the PKC-conserved region 2 (known as $\mathrm{C} 2$ domain). Once activated, it mediates the activation of the transcription factor NF- $\mathrm{KB}$ (nuclear factor for $\kappa$ gene in B lymphocytes) (OANCEA and MEYER, 1998; SAIJO et al., 2002; SHINOHARA et al., 2005). DAG additionally recruits the Ras guanine nucleotide-releasing proteins 1 and 3 (RasGRP1 and RasGRP3). Their activation then is PKC-dependent (TOGNON et al., 1998; OH-HORA et al., 2003; AIBA et al., 2004). RasGRP3 initiates the Ras signaling cascade in B cells which activates several further processes including the activation of the mitogen-activated protein (MAP)-kinase Erk (extracellular signal-regulated kinase) which activates the transcription factor Elk-1 (OH-HORA et al., 2003).

The soluble second messenger $\operatorname{IP}_{3}$ binds to ligand-gated $\operatorname{IP}_{3}$-receptors $\left(\mathrm{IP}_{3} \mathrm{R}\right)$ in the membrane of the endoplasmatic reticulum (ER) and induces the efflux of $\mathrm{Ca}^{2+}$ (KUROSAKI et al., 2000; PATTERSON et al., 2004; ENGELKE et al., 2007). The $\mathrm{IP}_{3^{-}}$ mediated $\mathrm{Ca}^{2+}$ release from the ER induces the opening of store-operated $\mathrm{Ca}^{2+}$ channels (SOC) in the plasma membrane leading to an influx of $\mathrm{Ca}^{2+}$ from the extracellular space. The functional relationship between ER-depletion and SOC activation remains widely unknown but one example which has been described is the entry through calcium release activated channels (CRAC). Thereby the stromal interaction molecule 1 (STIM1) and STIM2, which are localized in the membrane of the ER, detect the decrease of ER $\mathrm{Ca}^{2+}$ stores and communicate with the CRAC channel protein ORAI in the plasma membrane to trigger $\mathrm{Ca}^{2+}$ entry by a yet to be defined mechanism (WILLIAMS et al., 2001; ROOS et al., 2005; LIOU et al., 2005; PRAKRIYA et al., 2006). 
Cytosolic $\mathrm{Ca}^{2+}$ levels control the activity of the transcription factors NFAT (nuclear factor of activated T cells) and NF- $\mathrm{BB}$ (BAEUERLE and HENKEL, 1994; CRABTREE and CLIPSTONE, 1994; FRANTZ et al., 1994; NEGULESCU et al., 1994; RAO, 1994; FANGER et al., 1995; SHIBASKI et al., 1996; TIMMERMANN et al., 1996). The amplitude and duration of $\mathrm{Ca}^{2+}$ signals in $\mathrm{B}$ lymphocytes differentially activates these transcription factors. NF- $\kappa \mathrm{B}$ is selectively activated by a large transient rise of $\mathrm{Ca}^{2+}$ ions whereas NFAT is activated by a low, sustained $\mathrm{Ca}^{2+}$ plateau (DOLMETSCH et al., 1997).

$\mathrm{Ca}^{2+}$ ions mediate these activation processes by either, binding to proteins and directly influencing the activity of the enzymes, e.g. the protein kinase $\mathrm{C}$ (PKC) as described above, or indirectly by binding to regulatory proteins like Calmodulin. When associated with $\mathrm{Ca}^{2+}$ ions it regulates a plethora of proteins e.g. Calcineurin. Calcineurin then dephosphorylates and activates NFAT transcription factors which then translocate to the nucleus to regulate gene transcription (CRABTREE and OLSON, 2002; PARSONS et al., 2004).

$\mathrm{B}$ cells of distinct developmental stages have different $\mathrm{BCR}$-induced $\mathrm{Ca}^{2+}$ profiles. Naïve mature $\mathrm{B}$ cells mount a biphasic $\mathrm{Ca}^{2+}$ signal with $\mathrm{Ca}^{2+}$ mobilization from the ER and the extracellular space. Immature B cells in contrast mount only a weak influx of $\mathrm{Ca}^{2+}$ from the extracellular space. Deregulated $\mathrm{Ca}^{2+}$ responses have been associated with pathophysiological processes in several autoimmune and inflammatory diseases, e.g. systemic lupus erythematosus.

\subsection{Consequences of deregulated BCR signaling}

Signals mediated via the BCR are responsible for multiple processes in B cell development and maintenance. For different reasons it can happen that signals transduced via the BCR lead to compromised B cell functionality. Failure of BCR-induced signals can be characterized by defects in immunoglobulin (Ig) production; can result in excessive production of autoantibodies (autoimmunity) or the reduction/lack of specific Igs (immunodeficiencies), while defects regarding uncontrolled proliferation of B cells may result in lymphomas and leukemias.

Lymphomas of the B cell lineage can derive from B cells of all different developmental stages and due to their occurrence can be classified as those associated with infectious agents (e.g HIV), with host's immunosuppression, with deregulation of apoptosis and survival pathways, with deregulation of the cell cycle and with deregulation of the cell signaling and of transcriptional regulation (JAFFE et al., 2008). Diffuse large B cell 
lymphoma (DLBCL), for example, is a heterogenous diagnostic category consisting of molecular distinct subtypes, e.g. the activated B-cell-like (ABC). Key feature of ABCDLBCL is the constitutive activation of the NF- $\mathrm{KB}$ signaling pathway to block apoptosis (DAVIS et al., 2001). Recurrent CARD11 (Caspase recruitment domain-containing protein 11, also known as CARMA1 or Bimp3) mutations have been described in about 8-11\% of the ABC-DLBCL. In normal B cells, CARD11 is phosphorylated by PKC- $\beta$ upon BCR engagement which subsequently induces the activation of the IKB kinase (IKK), thereby initiating NF-אB signaling (SOMMER et al., 2005, MATSUMOTO et al., 2005). The CARD11 mutations potentiate its NF- $\kappa B$ transactivation activity (LENZ et al., 2008). Leaving a lot of ABC-DLBCLs with wild-type CARD11, a large group could be related with constitutive signaling via the BCR (also referred as 'chronic active' BCR signaling). Screenings in these lymphomas revealed mutations in BCR signaling effectors like Ig- $\beta$, which increase the BCR surface expression by inhibiting receptor internalization, as well as interfering with the feedback inhibition of BCR signaling. Thereby Ig- $\beta$ mutations have been shown to attenuate negative autoregulation by Lyn (DAVIS et al., 2010).

In contrast to hyperproliferative cells causing lymphomas, autoimmune diseases are correlated with B cells having defects in B cell tolerance, resulting in the generation of autoreactive antibodies. The autoimmune diseases can be classified as systemic (e.g. systemic lupus erythematosus [SLE] and rheumatoid arthritis [RA]), as organ-specific or localized (e.g TypI diabetes mellitus or multiple sclerosis [MS]) and as intermediate immunological disorders, the latter comprising systemic and local effects. Local autoimmune diseases tend to be associated with antibodies against local tissues, e.g. the insulin-producing $\beta$-cells of the pancreas (diabetes) or the myelin sheet of the central nervous system (MS). Systemic autoimmune diseases however are associated with autoantibodies directed against antigens that are not tissue specific. SLE is a prototype systemic autoimmune disease characterized by a extent defect in immune tolerance resulting in the development of a diverse repertoire of autoantibodies against secreted, cytoplasmic, and nuclear antigens and involvement of multiple organ systems including skin, kidneys, CNS and more (ARBUCKLE et al., 2003). Due to the variety of the disease many mouse models have been described that develop lupus-like phenotypes. Some of them display features of the human disease and reveal a pathogenic role of $\mathrm{B}$ cells in developing SLE beyond the production of autoantibodies as mice lacking antibody secretion still develop lupus-like phenotypes (CHAN et al., 1999). Further studies showed that the regulation of BCR signaling is responsible for several cases of SLE. Numerous 
lines of evidence suggest that BCR-mediated $\mathrm{Ca}^{2+}$ signals are abnormal in $\mathrm{B}$ cells from patients with SLE and that this is correlated with impaired negative regulation of the signal (LIOSSIS et al., 1996; PUGH-BERNARD and CAMBIER, 2006; ENYEDY et al., 2001). Studies in mouse models of SLE have demonstrated a clear association between the inhibitory function of the FcyRIIB receptor and disease susceptibility (BOLLAND et al., 2000, MACKAY et al., 2006). They could show that reduced expression of Fc $\gamma$ RIIB contributes to decreased FcyRIIB-mediated suppression of BCR-induced $\mathrm{Ca}^{2+}$ response in memory B cells of SLE patients. The observation, that some of the genes that contribute to lupus function by downregulating BCR signaling and impeding antigen-driven negative selection was supported by the analysis of further patient populations which showed that lupus is also linked to polymorphisms in BCR signaling effectors (e.g. tyrosine kinases) responsible for antigen-driven BCR responses (LIOSSIS et al., 1996). Data revealed that expression of Lyn was significantly decreased in resting as well as in antigen-stimulated B cells from SLE patients (LIOSSIS et al., 2001). Such defects are important because they might contribute to the loss of B cell tolerance observed in SLE.

BCR signaling effectors also have been associated with immunodeficiencies. X-linked agammaglobulinaemia (XLA) is a B cell immunodeficiency characterized by a defect in B cell development resulting in low numbers of mature B cells and a lack of Ig-production (LEDERMAN and WINKELSTEIN, 1985; OCHS and SMITH, 1996). These phenotypes have been mainly associated with defects in $\mathrm{Ca}^{2+}$ signaling of $\mathrm{B}$ cells which are caused by mutations in the $\mathrm{Ca}^{2+}$ initiating effector Btk (RAWLINGS et al., 1993; TSUKADA et al., 1994; VIHINEN et al., 1997; RAWLINGS, 1999). B cells from patients with mutations in Btk and $b t k^{-/-}$mice show strongly impaired $\mathrm{Ca}^{2+}$ influx upon BCR crosslinking (KHAN et al., 1995) and most XLA patients do not express detectable levels of Btk (SIDERAS et al., 1994). Nonetheless, about $15 \%$ of the XLA patients have no defects in the btk gene indicating that also other proteins of the BCR-proximal signal-transduction unit are affected. Indeed, mutations in the slp-65 gene have been identified in some patients (MINEGISHI et al., 1999). Similar observations were reported in SLP-65-deficient mice. They have defects in $\mathrm{B}$ cell development and activation resulting in xid-like immunodeficiencies (XU et al., 2000).

These are only a few examples showing that development, maintenance and elimination of $\mathrm{B}$ cells depends on BCR signaling, which has to be exactly regulated to keep the balance between humoral immunity and tolerance. 


\subsection{Modulation of BCR-mediated signaling processes}

Intracellular signaling regulates cellular responses important for lymphocyte development, activation, and maintenance of tolerance. B cells use several mechanisms to control BCR signaling. Although the underlying mechanisms are not completely understood one key element is a balanced action between positive and negative signaling events.

To exactly regulate intracellular signals $\mathrm{B}$ cells have a complex inhibitory machinery including immunoreceptor tyrosine-based inhibitory motif (ITIM)-bearing receptors (e.g. FcyRIIB, CD22) which recruit negative regulators like tyrosine phosphatases (e.g. SH2 domain-containg phosphatases, SHP), lipid phosphatases (e.g. SH2 domain-containing inositol 5'-phosphates, SHIP) and ubiquitin ligases (e.g Casitas B-lineage lymphoma, Cbl). Regulation by the transmembrane glycoprotein CD22 is an example for inhibitory signaling components counterbalancing activatory BCR effectors. When CD22 is coexpressed with the BCR it becomes tyrosine phosphorylated at its ITIM motifs by Lyn (CORNALL et al., 1998; SMITH et al., 1998). ITIM phosphorylation of CD22 leads to the recruitment of the tyrosine phosphatase SHP-1 (DOODY et al., 1995, SMITH et al., 1998). SHP-1 dephosphorylates several effectors, including Syk (TUSCANO et al., 1996; LAW et al., 1996) and Ig- $\alpha /-\beta$ (PANI et al., 1995), which in turn downregulates $\mathrm{Ca}^{2+}$ mobilizing enzymes.

Moreover signal regulation is organized by adaptor proteins. Adaptor molecules exert their function by mediating protein-protein or protein-lipid interactions without intrinsic enzymatic activities. Although these proteins have no intrinsic kinase or phosphatase activity they regulate signaling processes by recruiting proteins to signaling complexes and clusters (SAMELSON, 2002; LINDQUIST et al., 2003). Beyond activatory processes like e.g. SLP-65 mediated formation of the $\mathrm{Ca}^{2+}$ initiation complex, adaptor proteins also organize signal inhibiting effectors.

\subsubsection{The adaptor protein Grb2 is a key regulator of $\mathrm{BCR}$ mediated $\mathrm{Ca}^{2+}$ signaling}

One adaptor protein which has been identified as an important regulator in BCR signaling is the growth factor receptor-bound protein 2 (Grb2) (STORK et al., 2004; STORK et al., 2007; ENGELS et al., 2008; ENGELS et al., 2009).

Grb2 is an adaptor protein composed of a central Src homology 2 (SH2) domain, which is flanked by two SH3 domains and is ubiquitously expressed (CLARK et al., 1992; LOWENSTEIN et al., 1992; OLIVIER et al., 1993). Gene targeting experiments demonstrate a critical role for Grb2 as $g r b 2^{-/}$mice die during early embryogenesis 
(CHENG et al., 1998). Since its discovery multiplicities of binding partners have been described (OLIVIER et al., 1993; NEUMANN et al., 2009) (figure 2.2). The central SH2 domain is binding to phosphorylated tyrosines with the consensus sequence pYxN (KESSELS et al., 2002). By virtue of its SH3 domains Grb2 binds to proline rich regions (PRR) of multiple proteins, among which are central BCR signaling effectors like SLP-65 (with the C-terminal SH3 domain) or the guanine nucleotide exchange factor (GEF) son of sevenless (SOS) (with both SH3 domains) (figure 2.2) (LI et al., 1993; FUSAKI et al., 2000). Downstream of antigen-receptor signaling, Grb2 plays a divergent role. Upon T cell receptor (TCR)-induced stimulation it promotes MAPK pathways and the Lck-mediated increase of $\mathrm{Ca}^{2+}$ flux (JANG et al., 2010). In B cells Grb2 positively regulates BCRinduced Vav signaling (JOHMURA et al., 2003). Nonetheless, several lines of evidence show that Grb2 mainly mediates negative regulatory functions upon BCR engagement. It has been shown to promote CD22 phosphorylation in mouse B cells (JANG et al., 2009) and to negatively regulate $\mathrm{Ca}^{2+}$ mobilization (STORK et al., 2004). Decisive for Grb2 function downstream of BCR signaling is the subcellular localization of this cytoplasmic protein. Mature B cells express the transmembrane adaptor protein LATII (alternatively called NTAL or LAB [JANSSEN et al., 2003]) (BRDICKA et al., 2002; STORK et al., 2004). It becomes rapidly phosphorylated upon BCR activation and thus provides potential binding sites for the $\mathrm{SH} 2$ domain of Grb2. This binding was shown to counteract the capacity of Grb2 to attenuate BCR-induced $\mathrm{Ca}^{2+}$ flux (figure 2.4). In contrast B cells of the immature phenotype do not express LATII resulting in an attenuated $\mathrm{Ca}^{2+}$ response upon BCR engagement especially from the extracellular space (STORK et al., 2004). Herein, Grb2 can bind another, till this point unknown, protein responsible for negative regulation of the $\mathrm{Ca}^{2+}$ mobilization.

This central binding partner of Grb2, the adaptor protein Dok-3 (downstream of kinase-3), has been identified in 2007. The Dok-3/Grb2 protein-complex has been shown to negatively regulate $\mathrm{Ca}^{2+}$ signaling upon BCR stimulation (STORK et al., 2007).

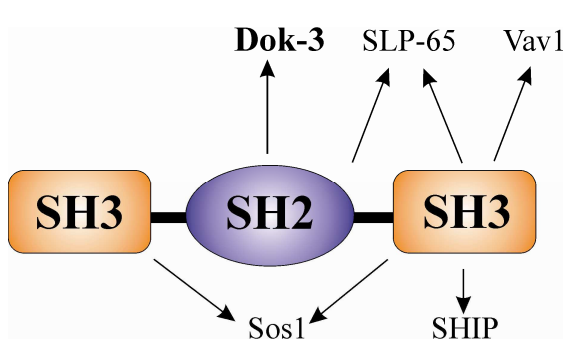

Figure 2.2: Grb2: schematic overview of its structure and examples for binding partners

Grb2 possesses a central $\mathrm{SH} 2$ domain (blue) flanked by two SH3 domains (orange). The SH2 domain is, amongst others, binding to Dok-3 and SLP-65 whereas the SH3 domains mediate interaction with proteins like Vav, Sos, SHIP and SLP-65. 


\subsubsection{The Dok adaptor proteins}

Till now seven members of the Dok family of adaptor proteins have been described (Dok-1 up to Dok-7). All proteins share structural similarities characterized by an N-terminal pleckstrin homology $(\mathrm{PH})$ domain, followed by a phospho-tyrosine binding (PTB) domain. The C-terminal region of the proteins contains several proline rich regions (PRR) and tyrosine-based phospho-acceptor sites (VEILLETTE et al., 2002). The PH domain binds to phospholipids and thus is mediating the plasma membrane localization of the proteins (LEMMON and FERGUSON, 1998; LEMMON, 2004). The PTB domain mediates protein-protein interactions, usually by interacting with short peptide sequences encompassing phosphorylated NPXY motifs (FORMAN-KAY and PAWSON, 1999; SLESSINGER and LEMMON, 2002).

\subsubsection{Dok proteins in immunoreceptor signaling}

Three members of the Dok family adaptors (Dok-1, Dok-2 and Dok-3) are expressed in hematopoietic cell lines. Dok-1 (also termed p62 ${ }^{\mathrm{dok}}$ ) is expressed in both, $\mathrm{T}$ and B lymphocytes, whereas Dok-2 (also termed Dok-R, FRIP or $\mathrm{p} 56^{\mathrm{dok}}$ ) is expressed in T cells and Dok-3 (also termed Dok-L) in B cells (LEMAY et al., 2000, YASUDA et al., 2004, YASUDA et al., 2007).

Dok-1 and Dok-2 are key regulators in TCR signaling. Mice lacking both proteins have an enhanced $\mathrm{IgG}$ response to thymus dependent antigens. $\mathrm{CD}^{+} \mathrm{T}$ cells from these mice have an enhanced proliferation and IL-2 production due to an increase in TCR-induced phosphorylation of ZAP-70, LAT and Erk (YASUDA et al., 2007). Individual knockdown of either Dok-1 or Dok-2 have only minimal effects implicating a redundant regulatory function (DONG et al., 2006). This is further supported by earlier data generated in cells of myeloid origin (NIKI et al., 2004; YASUDA et al., 2004).

The first physiological role demonstrated for Dok proteins in B cells was that of Dok-1 in BCR-mediated signaling pathways. Upon phosphorylation by Lyn it recruits the p120 Ras GTPase-activating protein (p120 RasGAP) and inhibits the activation of Ras and Erk. B cells from Dok-1 deficient mice show enhanced Erk activation implicating a negative regulatory function for this protein. However the Ig responses to thymus dependent (TD) and -independent (TI) antigens as well as $\mathrm{Ca}^{2+}$ flux and proliferation of the B cells are not enhanced (ELLIS et al., 1997; YAMANASHI and BALTIMORE, 1997; CARPINO et al., 1997; NELMS et al., 1998; JONES and DUMONT, 1998; TAMIR et al., 2000; YAMANASHI et al., 2000; OTT et al., 2002). 
Dok-3 function in B cells first has been described in 2000 by Lemay and colleagues. They showed that Dok-3 is highly expressed in several hematopoietic cells, including B cells, macrophages and myeloid cells and upon BCR engagement becomes highly tyrosine phosphorylated. In contrast to Dok-1 and -2, Dok-3 is not interacting with RasGAP proteins (CONG et al., 1999; LEMAY et al., 2000). Nonetheless, like Dok-1 and-2 it interacts with the inositol phosphates SHIP and the C-terminal Src kinase (Csk) (CHOW and VEILETTE, 1995). As both proteins are known negative regulators of BCR-induced signaling they postulated a negative regulatory function for Dok-3.

Indeed, following studies showed that association of Dok-3 with SHIP suppresses specifically BCR-mediated JNK activation whereas other MAPKs like Erk were not affected (ROBSON et al., 2004). In vitro studies in DT40 B cells gained further evidence for the negative regulatory function of Dok-3 as they showed that upon BCR stimulation Dok-3-deficient cells encompass a marked increase of intracellular $\mathrm{Ca}^{2+}$ levels compared to wild-type cells (STORK et al., 2007). The studies further revealed first insights into the molecular mechanisms underlying this negative regulatory function.

Upon BCR engagement Dok-3 becomes highly phosphorylated by the Src kinase Lyn. Due to its PH domain, Dok-3 is localized at the plasma membrane (GOLDBECK, 2007). Three tyrosine phosphorylation motifs have been described in avian Dok-3. The $\mathrm{Y}^{140}$ between the PH- and the PTB domain is necessary for formation of homo-oligomers of the protein as it is bound by the PTB domain of other Dok-3 proteins (STORK et al., 2007). The tyrosine residue at position 307 provides upon phosphorylation a binding site for Csk (LEMAY et al., 2000). Although this kinase has been shown to be involved in regulatory signaling processes like the phosphorylation of inhibitory tyrosines, e.g of Lyn, this interaction is dispensable for BCR-induced $\mathrm{Ca}^{2+}$ inhibition by Dok-3 (STORK et al., 2007). Association of Dok-3 with SHIP could be shown to be mediated via the PTB domain of Dok-3 (binding to $\mathrm{Y}^{1020}$ of SHIP) and $\mathrm{Y}^{331}$ (bound by the SH2 domain of SHIP). However, binding of Dok-3 to SHIP is likewise not essential for the inhibition of $\mathrm{Ca}^{2+}$ release. 


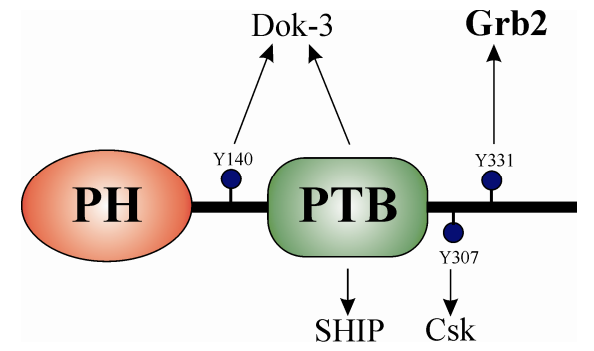

Figure 2.3: Schematic overview of the structure and binding partners of avian Dok-3

Dok-3 comprises an N-terminal $\mathrm{PH}$ domain (red) mediating its membrane recruitment by binding to phospholipids. The domain is followed by a PTB domain (green). This domain is interacting with phospho-tyrosine motifs in SHIP and mediates the formation of homooligomers. The C-terminal region comprises the $\mathrm{YxN}$ motif $\left(\mathrm{Y}^{331}\right)$ which is upon phosphorylation bound by the SH2 domain of Grb2. The tyrosines 140 (bound by the PTB domain of Dok-3) and 307 (bound upon phosphorylation by Csk) are dispensable for the $\mathrm{Ca}^{2+}$ inhibition mediated by Dok-3.

The third tyrosine residue at position 331 forms the consensus Grb2-SH2 domain binding motif YxN. Together with the PH domain, this motif has been shown to be indispensible for Dok-3-mediated signal inhibition.

The BCR-induced association with Grb2 further increases the phosphorylation of Dok-3 and has been shown to attenuate the Btk-dependent phosphorylation of PLC- $\gamma 2$ giving rise to a reduced $\mathrm{IP}_{3}$ production and thus to a diminished $\mathrm{Ca}^{2+}$ response. Similar amounts of increased $\mathrm{Ca}^{2+}$ responses in Grb2- and Dok-3-deficient cells (STORK et al., 2007) as well as in $g r b 2^{--}$and $d o k-3^{--}$primary B cells (NG et al., 2007; JANG et al., 2010) emphasize the concerted function of both proteins. Once Grb2 is recruited to the plasma membrane by Dok-3 the Grb2-cSH3 domain is essential to mediate signal inhibition (STORK et al., 2007). The data generated in the in vitro experiments were then supported by in vivo studies in Dok-3 deficient mice. These mice encompass a higher level of basal IgM antibodies and, in contrast to $d o k-1^{-/}$mice, an enhanced response to $\mathrm{T}$ cell-independent antigens. B cells from these mice are hyperproliferative, show higher levels of calcium flux and enhanced NF- $\mathrm{KB}$ and MAPK activation, further supporting the negative regulatory function of Dok-3 (NG et al., 2007).

Dok-3/Grb2 appears to be important for differential BCR-induced $\mathrm{Ca}^{2+}$ signals. In immature B cells Grb2 binds to phosphorylated Dok-3 upon BCR engagement. The complex then inhibits the rise of the cytosolic $\mathrm{Ca}^{2+}$ concentration mounting a weak $\mathrm{Ca}^{2+}$ signal (figure $2.4 \mathrm{~A}$ ). In contrast, in mature $\mathrm{B}$ cells the Dok-3/Grb2 function is compromised by the binding of Grb2 to LATII, which eliminates the negative regulatory function of Grb2 (B). These cells comprise a much more intensive $\mathrm{Ca}^{2+}$ signal upon BCR stimulation. 

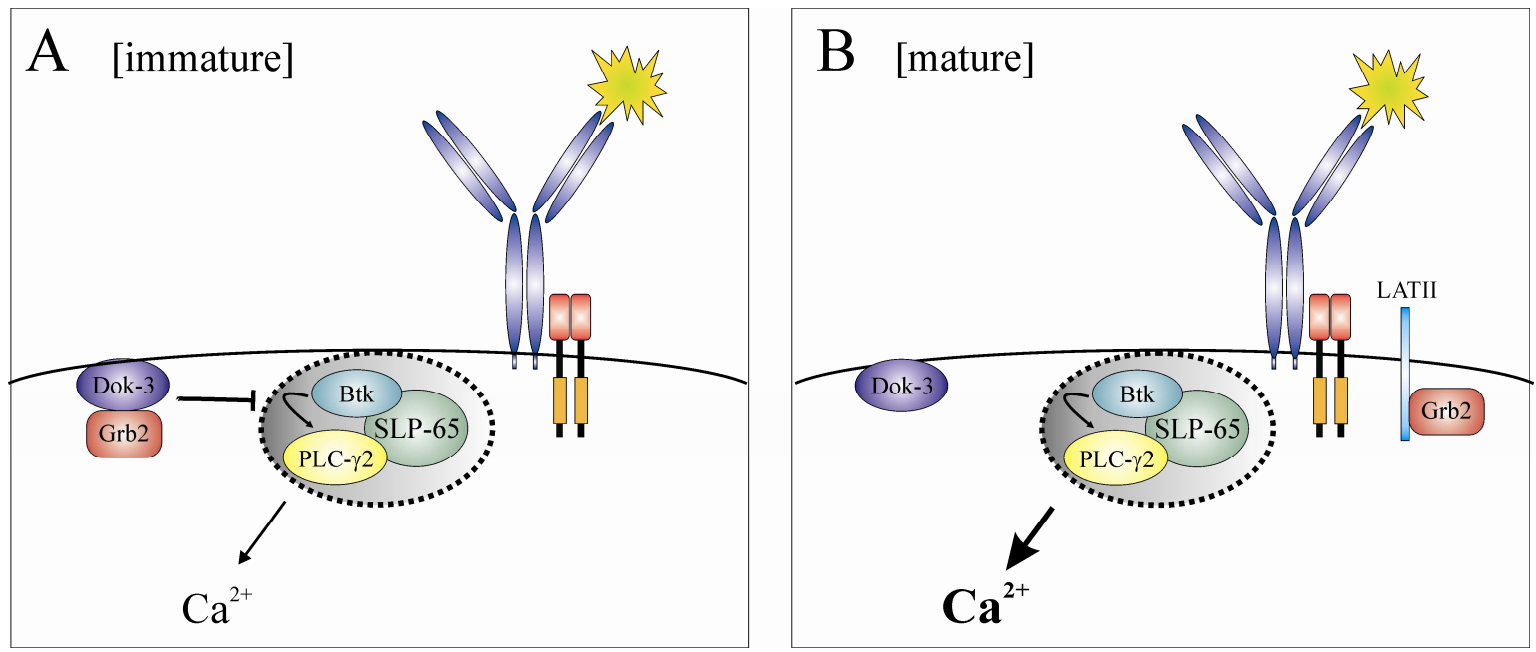

Figure 2.4: The alternative recruitment of Grb2 mediates inhibition of $\mathrm{Ca}^{2+}$ signaling

(A) Dok-3/Grb2 complex in BCR-induced $\mathrm{Ca}^{2+}$ mobilization of immature $\mathrm{B}$ cells. Binding of antigen (yellow) to the $\mathrm{BCR}$ leads to the formation of the $\mathrm{Ca}^{2+}$ initiation complex (grey) and the release of $\mathrm{Ca}^{2+}$ into the intracellular room. BCR engagement also induces the phosphorylation of the adaptor protein Dok-3 (blue) providing a binding site for Grb2 (red). Upon formation of the Dok-3/Grb2 complex the Btk-dependent phosphorylation of PLC- $\gamma 2$ (black arrow) is decreased resulting in a reduction of intracellular $\mathrm{Ca}^{2+}$ level. (B) Dok-3/Grb2 complex in BCR-induced $\mathbf{C a}^{2+}$ mobilization of mature B cells. Alternatively, BCR stimulation also leads to the phosphorylation of the transmambeane adaptor LATII (light blue). Phosphorylated LATII provides binding sites for Grb2 thus preventing it from its inhibitory function (modified from STORK et al., 2007).

Despite its importance for BCR signal regulation the molecular details of Dok-3/Grb2 function are poorly understood. Aim of this thesis was to elucidate the molecular mechanism of Dok-3/Grb2 mediated $\mathrm{Ca}^{2+}$ inhibition in B lymphocytes. 


\section{Aims of the Work}

BCR-induced $\mathrm{Ca}^{2+}$ mobilization and its regulation are mandatory for the generation of antigen-specific B lymphocytes. Several studies ascribe the adaptor-protein Dok-3 a key regulatory function in negative regulation of BCR mediated signaling. In vitro studies showed that the complex of Dok-3 and Grb2 inhibits the $\mathrm{Ca}^{2+}$ mobilization from intra- and extracellular stores whereas the molecular details of this inhibitory process remain elusive.

Aim of this thesis was to elucidate the molecular steps of Dok-3 mediated regulation of BCR stimulation. Therefore the DT40 B cell model system was used. This system is prone to a high frequency of homologous recombination, and therefore an appropriate tool for gene targeting and subsequent reconstitution experiments.

In detail I addressed the following questions:

[1] What is the underlying mechanism for the Grb2-dependency of Dok-3 tyrosine phosphorylation?

Several molecular details have been evaluated which are responsible for this effect. First the phosphorylation of the membrane associated Dok-3, second the binding of the Grb2-SH2 domain to phosphorylated Dok-3 and third the C-terminal SH3 domain of Grb2, whereas the exact function of the latter remains unclear. The role of the Grb2 binding and the role of its SH3 domain are investigated within this work.

[2] How does Dok-3 inhibit BCR-induced mobilization of $\mathrm{Ca}^{2+}$ ?

Previous studies showed that Dok-3 alters the tyrosine phosphorylation and the kinase activity of PLC- $\gamma 2$. The question yet to be answered is, at which point in the $\mathrm{Ca}^{2+}$ mobilizing signaling cascade Dok-3 alters the process. Thus the impact of Dok-3 on BCR-induced $\mathrm{Ca}^{2+}$ mobilization and regulation was investigated. 


\section{$4 \quad$ Results}

\subsection{Grb2 mediates the redistribution of Dok-3 into microsignalosomes}

Previous studies show that Dok-3 is a central regulator of differential BCR-induced signals. Essential for Dok-3 function is the Lyn-dependent complex formation of Dok-3 and Grb2. The minimal structural requirements of Dok-3/Grb2 mediated $\mathrm{Ca}^{2+}$ inhibition are the SH2 domain of Grb2 binding to Dok-3 and the C-terminal SH3 domain of Grb2, whereas the precise role of the latter is unknown to date (STORK et al., 2007). Moreover the efficiency of Dok-3 phosphorylation depends on Grb2-binding, leaving the molecular details of Dok-3/Grb2 complex formation elusive. In the first part of my thesis the precise role of Dok-3-associated Grb2 was addressed.

\subsubsection{Microsignalosomal abundance of Dok-3 is approved by an association of Grb2 and the microsignalosome resident Lyn}

Binding of antigen by the BCR induces redistribution and aggregation of the receptors into microcluster (DEPOIL et al., 2008). These domains compartmentalize cellular processes by serving as organizing platforms for the assembly of signaling molecules and are enriched in signaling effectors including Lyn, Syk, PLC- $\gamma 2$ as well as CD20 and CD40 (SOHN et al., 2008, WEBER et al., 2008). Therefore these areas are defined as microsignalosomes indicating that these are the regions where BCR induced signaling processes mainly occur (WEBER et al., 2008). The exact composition and formation of these membrane areas nonetheless is not known to date. Confocal laser scanning microscopy analysis showed that in wild-type DT40 B cells Dok-3 is constitutively residing at the plasma membrane (GOLDBECK, 2007). However, the analysis did not include any indication about its abundance in microsignalosomes.

The Src family kinase Lyn is constitutively associated with the BCR even when unligated (PLEIMAN et al., 1994). Moreover, Lyn is accumulated in the areas of BCR microsignalosomes (SOHN et al., 2008) and mediates Dok-3 tyrosine phosphorylation (STORK et al., 2007). Hence, I first tested whether Grb2 can link Dok-3 to the microsignalosomal resident Lyn.

Lyn-deficient $\left(\right.$ lyn $\left.^{-/}\right)$and HA-tagged wild-type Lyn-expressing cells were left untreated or stimulated via their BCR and lysates were subjected to affinity purification with GST fusion proteins of the full length Grb2 protein (GST-Grb2), its N-terminal SH3 domain (GST-nSH3) or the C-terminal SH3 domain (GST-cSH3). Purified Lyn was analyzed by 
immunoblotting using anti-HA antibodies (figure 4.1 A, upper panel). Anti-HA immunoblotting of cleared cellular lysates (CCL) revealed equal amounts of Lynexpression (lower panel). I was able to purify HA-Lyn with GST-Grb2 (lanes 1 and 2) and GST-cSH3 (lanes 5 and 6). Thereby, BCR stimulation led to more efficient purification of Lyn. Purification with GST-nSH3 revealed only a weak signal for stimulated cells (lanes 9 and 10) showing that the purification was restricted to the cSH3 domain. These results imply that Grb2 is associated with the BCR microsignalosomes.
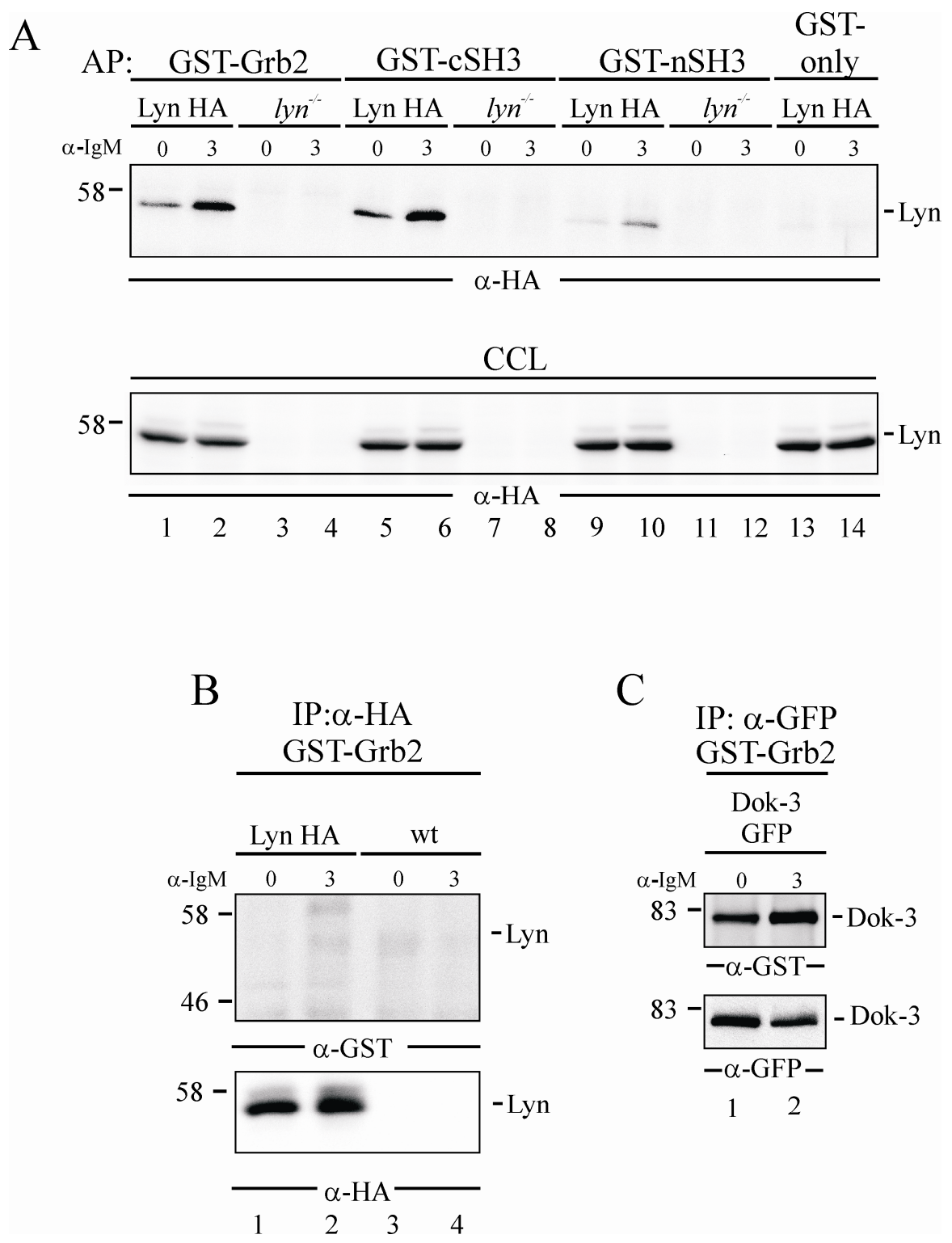
Figure 4.1: Grb2 is associated with Lyn in an indirect manner

(A) Lyn deficient $\left(l y n^{-/}\right)$and HA-tagged Lyn expressing DT40 cells were left untreated (0) or stimulated (3) via the BCR for $3 \mathrm{~min}$. Lysates were subjected to affinity purification with $10 \mu \mathrm{g}$ of GST only protein (GST-only; lanes 13 and 14) or GST-fusion proteins of either the fullength Grb2 protein (GST-Grb2; lanes 1-4), the C-terminal SH3 domain (GST-cSH3; lanes 5-8) or the N-terminal SH3 domain (GST-nSH3; lanes 9-12). Purified proteins were separated via SDS-PAGE and analyzed by immunoblotting using anti-HA antibodies (upper panel). Equal protein expression was analyzed by anti-HA immunoblotting of cleared cellular lysates (CCL) (lower panel). (B) For Far Western analysis, $l y n^{-/-}$cells expressing Lyn HA (lanes 1 and 2) and DT40 wild-type cells (lanes 3 and 4) were left untreated (0) or stimulated (3) via the BCR. Lyn was immunoprecipitated from cellular lysates using anti-HA antibodies and subjected to western blotting. Membrane was incubated with purified GST-Grb2 fusion protein and with anti-GST antibodies (upper panel). Equal protein amounts were controlled by reprobing the blot with anti-HA antibodies (lower panel). (C) Dok-3-GFP was immunoprecipitated from cellular lysates of unstimulated (0) and BCR-stimulated (3) Dok-3-GFP expressing DT40 cells. Far western blot analysis was performed as described in (B). Equal protein amounts were controlled by anti-GFP immunoblotting (lower panel). Molecular protein mass standards $(\mathrm{kDa})$ are indicated on the left $(\mathrm{A}-\mathrm{C})$

To address the question whether the binding of Grb2-cSH3 to Lyn is mediating the translocation into the microsignalosomes a far western blot analysis was done. Lyn was immunoprecipitated from $l y n^{-/}$cells expressing HA-tagged Lyn using anti-HA antibodies. Purified protein was subjected to far western blot analysis using purified GST-Grb2 fusion protein and subsequently anti-GST antibodies. No signal was detectable showing that there is no direct Lyn/Grb2 interaction (figure $4.1 \mathrm{~B}$, upper panel). As positive control, GFPfused Dok-3 was purified with GFP-antibodies and analyzed with GST-Grb2 fusion protein and anti-GST antibodies (figure 4.1 C, upper panel). As expected, GST-Grb2 binds to Dok-3 and signal intensity increases for samples from stimulated cells. Equal amounts of purified protein were proven by immunoblot analysis using anti-HA antibodies for Lyn (B, lower panel) or anti-GFP antibodies for Dok-3 (C, lower panel).

These data show that Grb2-SH3 can link the Dok-3/Grb2 complex to Lyn in BCR microsignalosomes. However, the association is not direct.

\subsubsection{Relocalization of Dok-3/Grb2 to microsignalosomes is depending on Vav3 and SLP-65}

It has been shown earlier that efficient BCR-induced Dok-3 phosphorylation requires Grb2 with a functional SH2 and cSH3 domain (STORK et al., 2007). Considering the data described above it appears likely that efficient Lyn-mediated phosphorylation of Dok-3 depends on the microsignalosome abundance of Dok-3/Grb2 complexes and that this process is mediated by the $\mathrm{cSH} 3$ domain of $\mathrm{Grb} 2$. 
I utilized this fact to screen for putative binding partners of the Grb2-cSH3 domain that support the relocalization of Dok-3/Grb2 into BCR microsignalosomes. I screened Dok-3 phosphorylation in cells lacking expression of Grb2-cSH3 interactors to identify the proteins being required for Dok-3 relocalization into microsignalosomes. As negative control $l y n^{-/}$and $g r b 2^{-/-}$DT40 B cells were used. Cells were left untreated or stimulated via their BCR. Lysates were subjected to immunoblot analysis using anti-pTyr antibodies (figure 4.2). In contrast to wild-type DT40 cells (lanes 1 and 2), Vav3-deficient (lanes 5 and 6) and SLP-65-deficient cells (lanes 11 and 12) showed a weak phospho-tyrosines signal at the apparent molecular weight of Dok-3. Lack of both proteins, respectively, suppresses the increase of Dok-3 phosphorylation upon BCR stimulation. Equal loading was confirmed using anti-actin antibodies (lower panel).

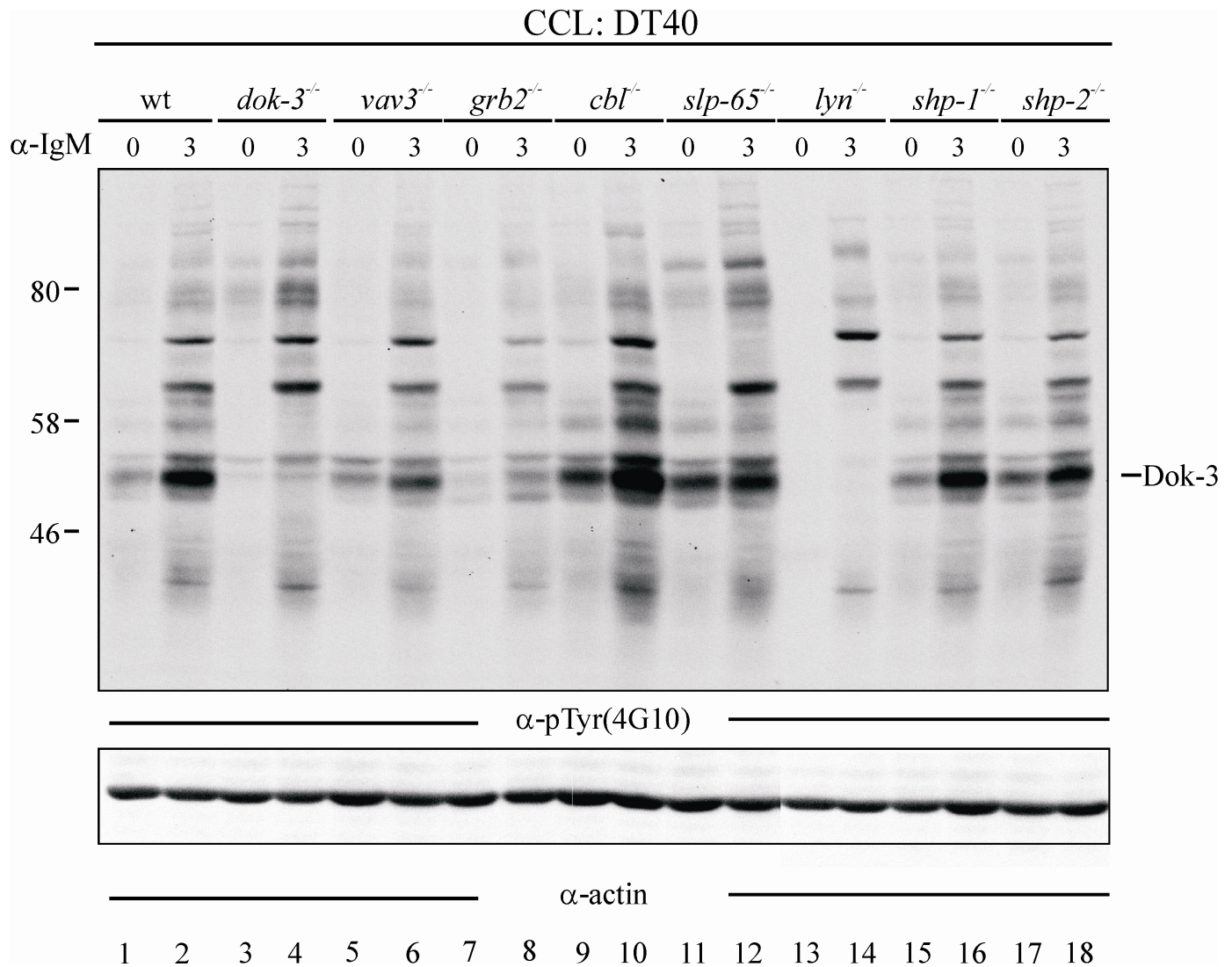

Figure 4.2: The BCR-induced phosphorylation of Dok-3 is impaired in DT40 cells lacking SLP-65- and Vav3-expression

DT40 wild-type cells (wt, lanes 1 and 2), Dok-3-deficient (dok-3 ${ }^{--}$, lanes 3 and 4), Vav3-deficient ( vav $^{-/}$, lanes 5 and 6), Grb2-deficient ( $\mathrm{grb2}^{-/}$, lanes 7 and 8), Cbl-deficient $\left(\mathrm{cbl}^{-/}\right.$, lanes 9 lanes 10),

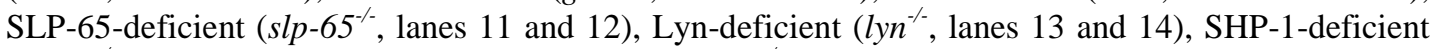
$\left(s h p-1^{--}\right.$, lanes 15 and 16) and SHP-2-deficient $\left(s h p-2^{--}\right.$, lanes 17 and 18) cells were left untreated (0) or BCR-stimulated (3) for $3 \mathrm{~min}$. CCLs were subjected to SDS-PAGE and analyzed with anti-pTyr immunoblotting (upper panel). Equal protein loading was controlled by anti-actin immunoblotting (lower panel). Molecular protein mass standard $(\mathrm{kDa})$ is indicated on the left. 
Figure 4.2 indicates a role of Vav3 and SLP-65 in mediating microsignalosomal Dok-3 phosphorylation. To further specify obtained results in these two genetic variants I retrovirally transfected wild-type DT40 cells and cells deficient for Vav3, SLP-65 or Grb2 with DNA encoding wild-type Dok-3-GFP. Cells were left untreated or stimulated via the BCR. Lysates were subjected to immunoprecipitation with anti-GFP antibodies and the phosphorylation status of purified Dok-3 was analyzed by immunoblotting with anti-pTyr antibodies (figure 4.3 A, upper panel). Analysis with anti-GFP antibodies revealed equal amounts of purified protein (figure $4.3 \mathrm{~A}$, lower panel).
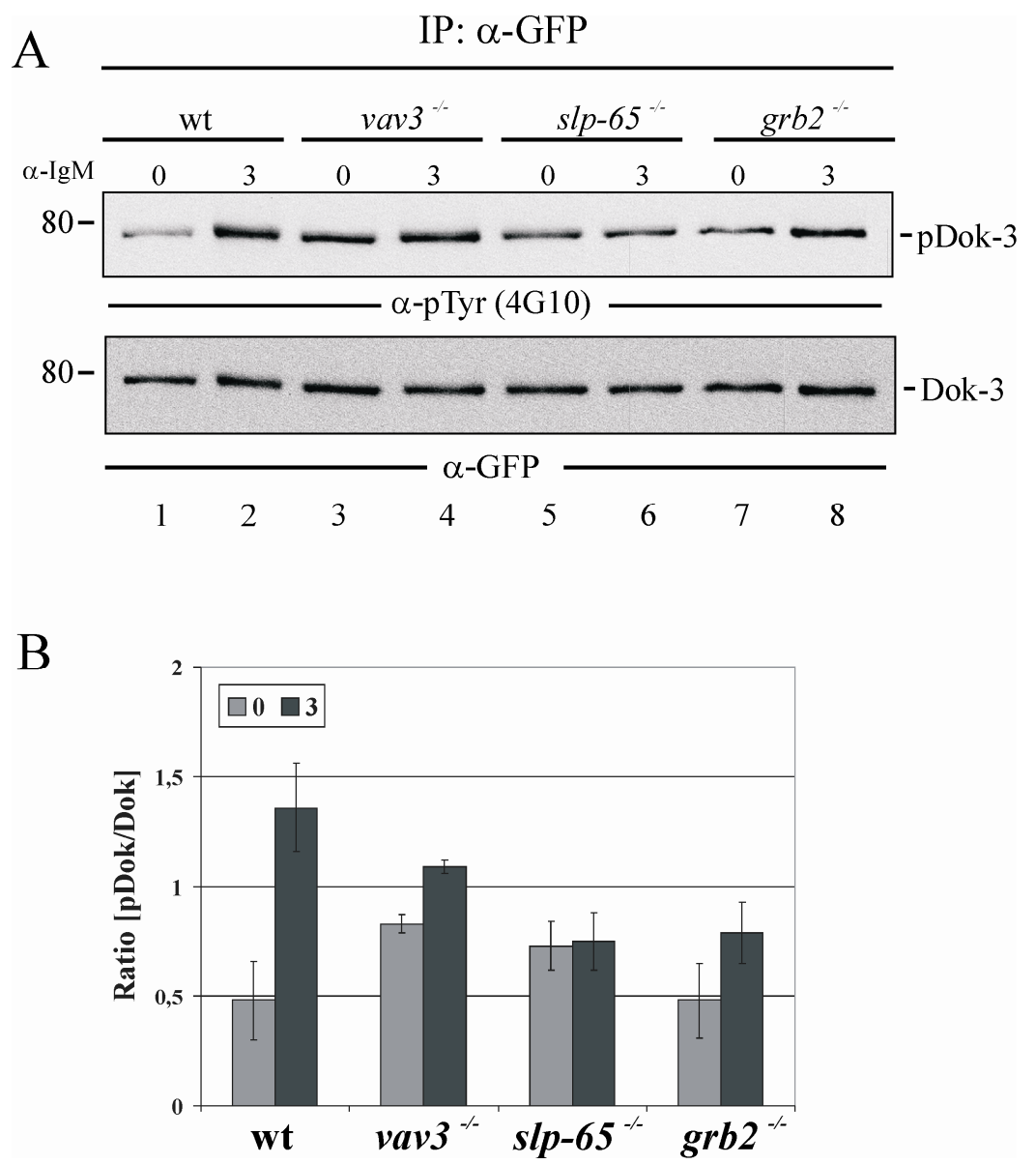

\section{Figure 4.3: The BCR-induced Dok-3 phosphorylation is compromised in Vav3- and SLP-65-} deficient cells

(A) DT40 wt, $v a v 3^{-/}, s l p-65^{-/}$and $g r b 2^{-/}$cells were retrovirally transfected with DNA encoding wildtype Dok-3-GFP. Cell were either left untreated (0) or stimulated (3) via the BCR for 3 min. Cellular lysates were subjected to immunoprecipitation with anti-GFP antibodies and purified Dok-3 was analyzed by immunoblotting using anti-pTyr (upper panel) and anti-GFP (lower panel) antibodies. Molecular mass protein standard (kDa) is indicated on the left. (B) Using ImageJ software ratios of anti-pTyr versus anti-GFP signals was calculated. Results are shown as mean values \pm standard deviation (s.d.) of three independent experiments. 
As shown in lanes 1 and 2 of figure 4.3 (A), Dok-3 is weakly phosphorylated in unstimulated wild-type DT40 cells and phosphorylation is markedly increased upon BCR stimulation. In contrast Vav3-deficiency leads to a slightly higher basal phosphorylation status of Dok-3 in unstimulated cells (lane 3) but BCR engagement did not alter the Dok-3 phosphorylation significantly (lane 4). Cells that are SLP-65-deficient also have an increased basal phosphorylation (lane 5). Similar to $v a v 3^{-/}$cells there is no marked increase in phosphorylation upon stimulation (lane 6). Grb2-deficiency, which is known to result in an impaired Dok-3 phosphorylation, serves as control (lanes 7 and 8). The observation is confirmed by densitometrically analysis of three independent experiments. Ratios of signal intensities of anti-pTyr versus anti-GFP are displayed in figure 4.3. I could show that similar to $\mathrm{grb2}^{-/}$cells BCR-induced Dok-3 phosphorylation is compromised in DT40 cells lacking Vav3- or SLP-65-expression.

The data reveal that Vav3 and SLP-65 are important to relocalize Dok-3/Grb2 into BCR microsignalosomes. Thus I next wanted to see whether Grb2 is still associated with Lyn in absence of Vav3 or SLP-65. Therefore I transfected wild-type DT40 cells and cells deficient for either Vav3 or SLP-65 with DNA encoding HA-tagged Lyn. Lysates of unstimulated and BCR-stimulated cells were subjected to affinity purification with GST fusion proteins the C-terminal SH3 domain (GST-cSH3). Purified Lyn was analyzed by immunoblotting using anti-HA antibodies (figure 4.4, upper panel). Anti-HA immunoblotting of cleared cellular lysates (CCL) revealed equal amounts of Lynexpression (third panel). Like already seen in figure 4.1, Lyn could be purified with the cSH3 domain from Lysates of wild-type DT 40 cells (lanes 3 and 4) and amount of purified protein increases upon BCR-stimulation. In contrast to wild-type DT40 cells (lanes 3 and 4), Vav3-deficient (lanes 5 and 6) and SLP-65-deficient cells (lanes 7 and 8) showed a marked decrease of purified Lyn and a loss of BCR-induced increase of purified protein amounts. Purification with GST-only protein (second panel) and in wild-type DT40 cells not expressing HA-tagged Lyn (lanes 1 and 2) revealed this interaction to be specific. The data support the finding that Vav3 and SLP-65 are involved in the relocalization of Dok-3/Grb2 into BCR microsignalosomes. 


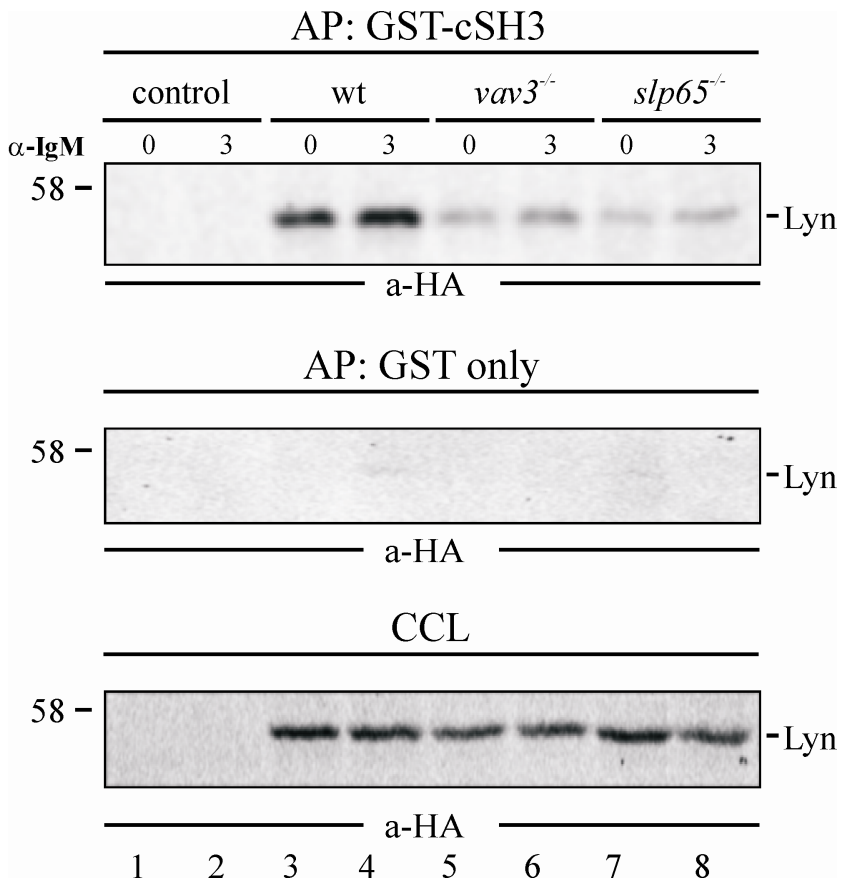

Figure 4.4: The association of Grb2 and Lyn is narrowed in cells deficient for Vav3 and SLP-65

(A) Wild-type DT40 cells (control, lanes 1 and 2) and HA-tagged Lyn expressing wild-type (lanes 3 and 4), Vav-deficient (lanes 5 and 6) and SLP-65-deficient (Lanes 7 and 8) DT40 cells were left untreated (0) or stimulated (3) via the BCR for $3 \mathrm{~min}$. Lysates were subjected to affinity purification with $10 \mu \mathrm{g}$ of GST-fusion proteins of the C-terminal SH3 domain (GST-cSH3; first panel) or GST only protein (second panel). Purified proteins were separated via SDS-PAGE and analyzed by immunoblotting using anti-HA antibodies. Equal protein expression was analyzed by anti-HA immunoblotting of cleared cellular lysates (CCL) (third panel). Molecular mass protein standard $(\mathrm{kDa})$ is indicated on the left.

\subsubsection{Providing microsignalosome abundance of Dok-3 is not the only function of the C-terminal SH3 domain of Grb2}

Grb2 is important for microsignalosomal localization of Dok-3, as I could show above. Next the question was addressed whether Grb2 function is restricted to Dok-3 relocalization. For this purpose we generated constructs coding for a chimera that is directly recruited to the microsignalosomes upon BCR engagement in a Grb2 independent manner. In this chimeric protein the PH domain of Dok-3 was substituted by the tandemSH2 domains of Syk (figure 4.5 A). Additional substitution of tyrosine residue in position 331 of Dok-3 by phenylalanine abrogates the interaction of Dok-3 and Grb2. Upon BCR stimulation the chimeras (TSH2-Dok-3 wt and TSH2-Dok-3 $\mathrm{Y}^{331} \mathrm{~F}$ ) are directly recruited to the phosphorylated ITAM. These experiments were done in co-operation with Michael Engelke. Constructs encoding for GFP-fused chimeras as well as Dok-3 wt and Dok-3 $\mathrm{Y}^{331} \mathrm{~F}$ were retrovirally transfected into $d o k-3^{-/-}$cells. Confocal laser scanning microscopy 
analysis revealed that both chimeras were recruited to the plasma membrane within 3 min after BCR stimulation (figure 4.5 B).

A

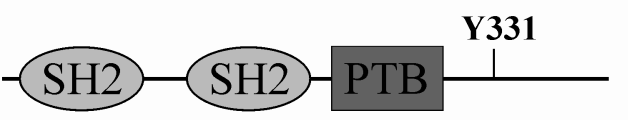

TSH2-

Dok-3 wt-GFP
$\mathrm{B}$
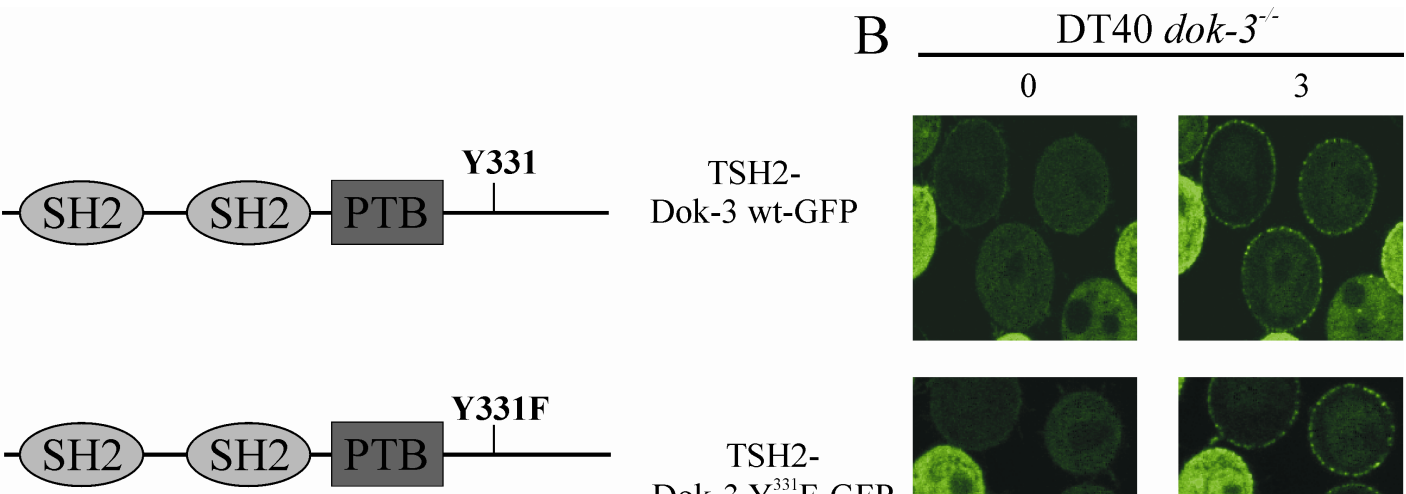

TSH2Dok-3 $\mathrm{Y}^{331} \mathrm{~F}-\mathrm{GFP}$
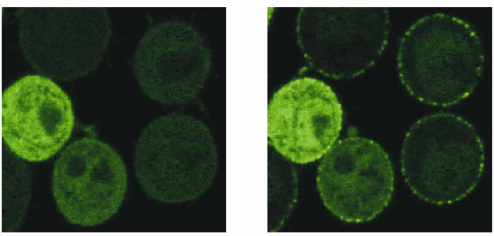

C IP: $\alpha$-GFP

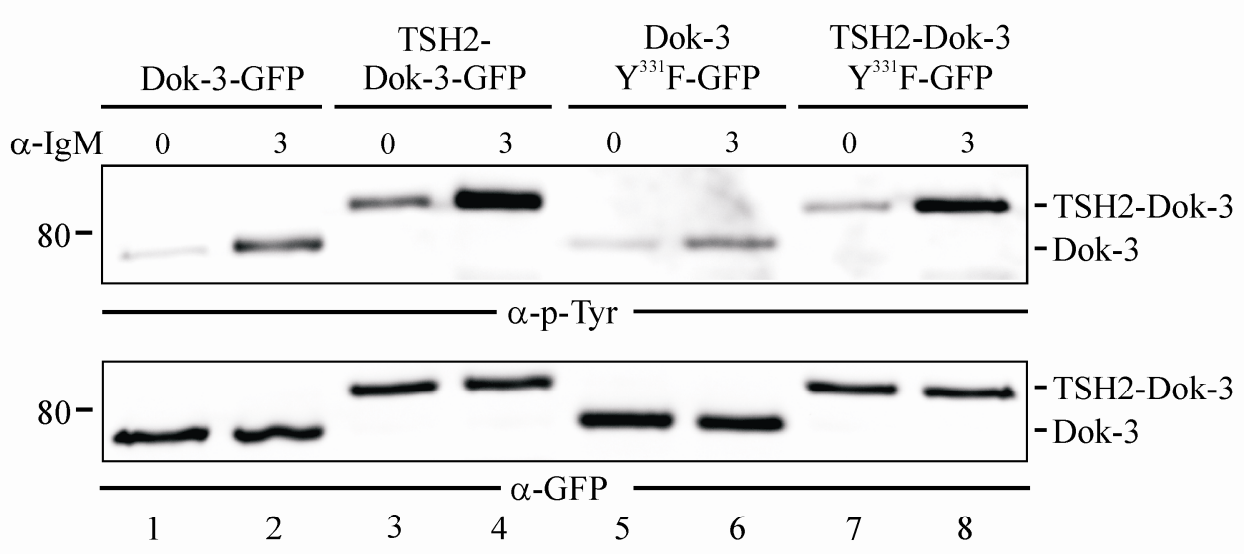

$\mathrm{D}$

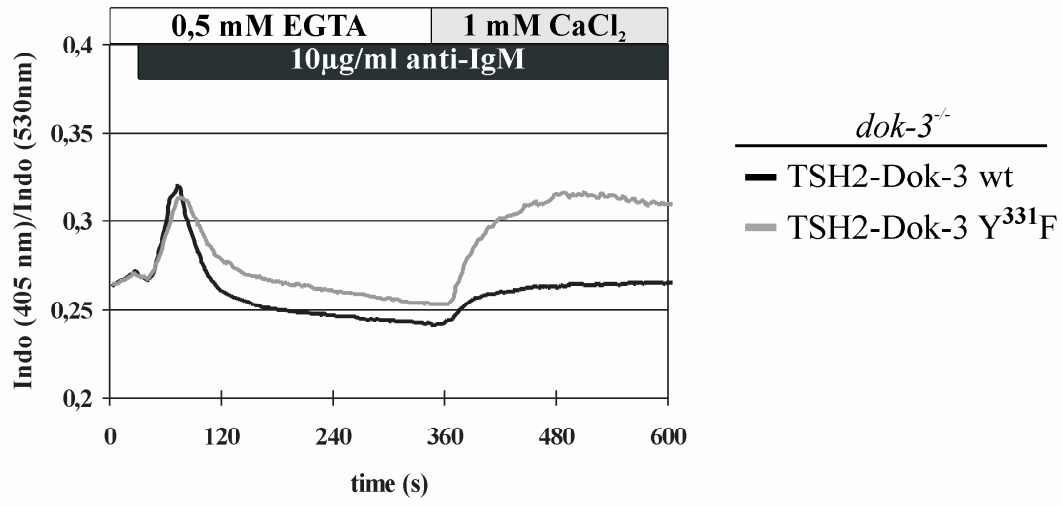

Figure 4.5 (legend see next page) 
Figure 4.5: Grb2 contributes to the Dok-3-mediated negative regulation of BCR signals in BCR microsignalosomes

(A) Domain structure of the TSH2-Dok-3 chimeric proteins. The PH domain of Dok-3 was substituted by the tandem SH2 domain of Syk (upper panel). Additionally the $\mathrm{Y}^{331}$, necessary for Grb2 binding, was substituted by phenylalanine (lower panel). (B) Subcellular distribution of the chimeras was analyzed using confocal laser scanning microscopy. Dok-3 deficient cells were either reconstituted with the GFP-tagged wild-type chimera (TSH2-Dok-3 wt; upper panel) or the $\mathrm{Y}^{331} \mathrm{~F}$ mutant (TSH2-Dok-3 $\mathrm{Y}^{331} \mathrm{~F}$; lower panel) and distribution was monitored before (0) and 3 min (3) after BCR induced stimulation. (C) Dok-3 deficient cells either expressing GFP-tagged Dok-3 wt (lanes 1 and 2), TSH2-Dok-3 wt (lanes 3 and 4), Dok-3 $\mathrm{Y}^{331} \mathrm{~F}$ (lanes 5 and 6) or TSH-Dok-3 $\mathrm{Y}^{331} \mathrm{~F}$ (lanes 7 and 8) were left untreated (0) or stimulated (3) via the BCR for 3 min. Cellular lysates were subjected to immunoprecipitation with anti-GFP antibodies and purified proteins were analyzed by immunoblotting using anti-pTyr (upper panel) and anti-GFP (lower panel) antibodies. Molecular mass standard $(\mathrm{kDa})$ is indicated on the left. (D) Cells described in (B) were loaded with Indo-1 and BCRinduced $\mathrm{Ca}^{2+}$ release from intracellular stores was measured for $6 \mathrm{~min}$ in presence of $0.5 \mathrm{mM}$ EGTA. Extracellular $\mathrm{Ca}^{2+}$ concentration was restored to $1 \mathrm{mM}$ and $\mathrm{Ca}^{2+}$ flux over the plasma membrane was monitored for another $4 \mathrm{~min}$.

The generated cells were next used to analyze the tyrosine phosphorylation efficiency of the chimeras compared to wild-type Dok-3. The proteins were immunoprecipitated from lysates of unstimulated and stimulated cells using GFP-antibodies. Phosphorylation of the proteins was analyzed by anti-pTyr immunoblotting (figure $4.5 \mathrm{C}$, upper panel) and equal purification and loading were controlled using anti-GFP antibodies (lower panel). In comparison to wild-type Dok-3 (upper panel, lanes 1 and 2) TSH2-Dok-3 is already phosphorylated in resting cells (lane 3 ) and becomes more efficiently phosphorylated after BCR engagement (lane 4). As expected, BCR-induced phosphorylation of Dok-3 $\mathrm{Y}^{331} \mathrm{~F}$ is markedly reduced compared to wild-type Dok-3 (lanes 5 and 6). In contrast, TSH2-Dok-3 $\mathrm{Y}^{331} \mathrm{~F}$ was significantly phosphorylated upon BCR engagement (lanes 7 and 8) similar to the TSH-Dok-3 wt. This further proves that BCR microsignalosome abundance is mandatory for efficient phosphorylation of Dok-3.

Next it was tested whether Grb2 is required for Dok-3/Grb2-mediated BCR signal regulation once residing in microsignalosomes. Hence, transfectands described above were loaded with Indo- 1 and $\mathrm{Ca}^{2+}$ release from the ER was monitored by flow cytometry for 6 min in presence of $0.5 \mathrm{mM}$ EGTA. The extracellular $\mathrm{Ca}^{2+}$ concentration was restored to 1 $\mathrm{mM}$ and the influx of $\mathrm{Ca}^{2+}$ through the plasma membrane was recorded for another $4 \mathrm{~min}$. Compared to TSH2-Dok-3 wt-expressing cells, DT40 cells that express TSH2-Dok-3 $\mathrm{Y}^{331} \mathrm{~F}$ show an increased BCR-induced $\mathrm{Ca}^{2+}$ mobilization from intra- and extracellular sources (figure $4.5 \mathrm{D}$, black and grey line).

These data show that beyond mediating correct localization of Dok-3, Grb2 contributes to further processes leading to attenuated $\mathrm{Ca}^{2+}$ release. 


\subsection{The Dok-3/Grb2 complex modulates the Lyn-dependent phosphorylation of BCR signaling effectors}

In the first part of the thesis I could elucidate the details of BCR-induced relocalization of Dok-3/Grb2 into BCR microsignalosomes. In the following part the details of Dok-3/Grb2mediated signal inhibition within the BCR microsignalosomes were examined.

\subsubsection{The Dok-3/Grb2 complex regulates effector functions upstream of the $\mathrm{Ca}^{2+}$ initiation complex}

It was shown previously that Dok-3/Grb2 reduces the BCR-induced $\mathrm{IP}_{3}$ production caused by a reduced PLC- $\gamma 2$ activity (Stork et al., 2007). As activation of PLC- $\gamma 2$ is mediated by Btk (Humphries et al., 2004) it was hypothesized that Dok-3/Grb2 directly regulates Btk function.

\subsubsection{The Dok-3/Grb2 complex still inhibits BCR-induced $\mathrm{Ca}^{2+}$ mobilization when Btk is absent from the $\mathrm{Ca}^{2+}$ initiation complex}

Binding of Btk to phosphorylated SLP-65 is crucial for the activation of PLC- $\gamma 2$. DT40 cells lacking Btk expression show no $\mathrm{Ca}^{2+}$ response upon BCR engagement whereas cells, expressing a SLP-65 variant (SLP-65 $\mathrm{Y}^{115} \mathrm{~F}$ ) incapable for Btk-binding, have a markedly reduced $\mathrm{Ca}^{2+}$ response. Plasmids encoding either wild-type Dok-3 or the Dok-3 $\mathrm{Y}^{331} \mathrm{~F}$ variant were transfected into SLP-65 $\mathrm{Y}^{115} \mathrm{~F}$ and wild-type SLP-65 expressing cells. It has been shown earlier that Dok-3 $\mathrm{Y}^{331} \mathrm{~F}$ acts dominant negative over endogenous Dok-3. Transfectands were loaded with Indo- 1 and $\mathrm{Ca}^{2+}$ flux from intra- and extracellular sources was monitored for $4 \mathrm{~min}$.

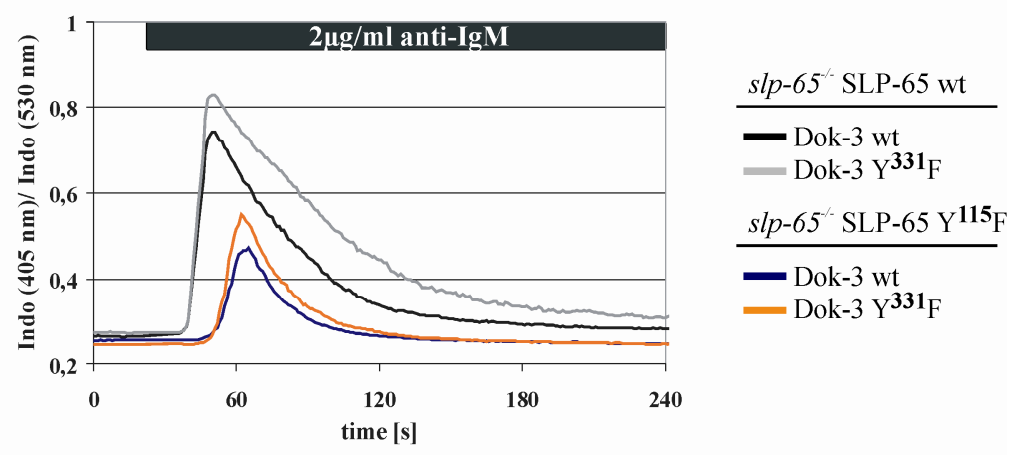

Figure 4.6: Dok-3 still influences a Btk binding deficient SLP-65

Cells expressing either wildtype SLP-65 (black and grey lines) or the $\mathrm{Y}^{115} \mathrm{~F}$ variant (blue and orange lines) together with wild-type Dok3 or Dok-3 $\mathrm{Y}^{331} \mathrm{~F}$ were loaded with Indo-1 and BCRinduced $\mathrm{Ca}^{2+}$ release was monitored for $4 \mathrm{~min}$ in presence of $1 \mu \mathrm{M} \mathrm{CaCl}_{2}$. 
DT40 cells expressing the SLP-65 $\mathrm{Y}^{115} \mathrm{~F}$ variant show a delayed and reduced $\mathrm{Ca}^{2+}$ flux compared to cells expressing the wild-type SLP-65 (figure 4.6, blue and black lines). Moreover, Dok-3 $\mathrm{Y}^{331} \mathrm{~F}$ has a dominant negative effect on the signal, in both, wild-type SLP-65 and the $\mathrm{Y}^{115} \mathrm{~F}$ expressing cells, evident from an increased $\mathrm{Ca}^{2+}$ signal (figure 4.6, grey and orange lines, respectively) in comparison to cells expressing wild-type Dok-3 respectively (black and blue lines, respectively).

These data show that Dok-3/Grb2 can regulate BCR-induced $\mathrm{Ca}^{2+}$ mobilization independent of Btk.

\subsubsection{Dok-3/Grb2 decrease the BCR-induced SLP-65 phosphorylation}

Phosphorylation of SLP-65 is the key event in BCR-induced formation of the $\mathrm{Ca}^{2+}$ initiation complex (KUROSAKI and TSUKADA, 2000). I next tested whether Dok-3/Grb2 changes the phosphorylation of PLC- $\gamma 2$ binding sites in SLP-65 which would also result in a decreased PLC- $\gamma 2$ activity.

Dok-3-deficient cells and wild-type Dok-3 reconstituted cells were transfected with DNA coding for Citrin-tagged human SLP-65. SLP-65 was purified from cellular lysates of unstimulated and stimulated cells using anti-GFP antibodies and the phosphorylation status of purified SLP-65 was analyzed by anti-pTyr immunoblotting (figure 4.7, upper panel).

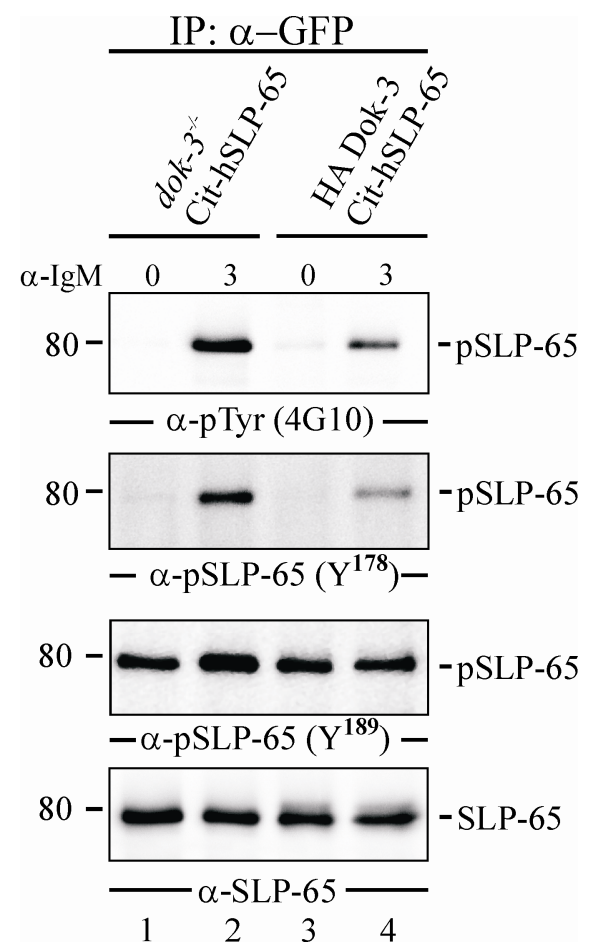

Figure 4.7: Dok-3 expression leads to decreased BCR-induced SLP-65 phosphorylation

Dok-3-deficient cells expressing either CitrinhSLP-65 alone (lanes 1 and 2) or together with wildtype Dok-3 (lanes 3 and 4) were left untreated (0) or stimulated (3) via the BCR for $3 \mathrm{~min}$, lysed and subjected to anti-GFP immunoprecipitation. Samples were subjected to SDS-PAGE and phosphorylation was detected via immunoblotting either with antipTyr antibodies (upper panel) or phospho-Tyr-site specific antibodies against $\mathrm{Y}^{178}$ (second panel) and $\mathrm{Y}^{189}$ (third panel). Equal loading was controlled by reprobing the membrane with anti-SLP-65 antibodies (lower panel). Molecular mass protein standards $(\mathrm{kDa})$ are indicated on the left. 
This analysis revealed that SLP-65 becomes phosphorylated upon BCR engagement (lanes 2 and 4) and that SLP-65 phosphorylation is markedly decreased in cells expressing Dok-3 (lane 4) in comparison to $d o k-3^{-/}$cells (lane 2). Additional analysis with antibodies that are specific for phosphorylated tyrosines of either of the two major PLC- $\gamma 2$ binding sites in human SLP-65 (Chiu et al., 2002) revealed that BCR-induced phosphorylation of especially $\mathrm{Y}^{178}$ (second panel) and to a lower extend of $\mathrm{Y}^{189}$ (third panel) was weaker in cells expressing Dok-3 (lane 4). Detection with anti-SLP-65 antibodies (lower panel) served as control for equal amounts of purified protein.

Taken together, these data show that the Dok-3-dependent reduction of PLC- $\gamma 2$ activity is caused by a decreased SLP-65 phosphorylation.

\subsubsection{Dok-3 expression decreases the BCR-induced Syk activation}

As phosphorylation of SLP-65 is mediated by Syk (FU et al., 1998), I next examined the influence of Dok-3 on this kinase.

\subsubsection{Dok-3 attenuates BCR-induced phosphorylation of Syk}

Dok-3-deficient cells, wild-type reconstituted cells and $s y k^{-/-}$cells were either left untreated or stimulated for 3 min via their BCR. Lysates were subjected to affinity purification with a biotinylated peptide mimicking the phosphorylated ITAM motif of Ig- $\alpha$ (Engels, 2004) and phosphorylation of purified proteins was analyzed by anti-pTyr immunoblotting (figure 4.7, upper panel). In contrast to $d o k-3^{-/}$cells (lane 2) BCR-induced Syk phosphorylation is clearly decreased in cells expressing Dok-3 (lane 4).

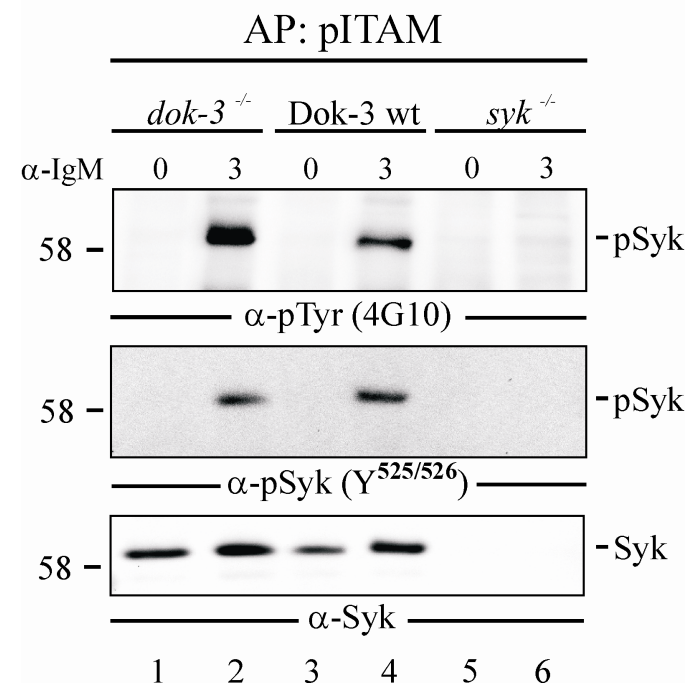

Figure 4.8: Dok-3 expression leads to decreased BCR-induced Syk phosphorylation

Syk was precipitated from untreated (0) or BCRstimulated (3) DT40 cells, that were either Dok-3 deficient (lanes 1 and 2), Dok-3 wt reconstituted (lanes 3 and 4) or Syk-deficient (lanes 5 and 6), as control. Precipitation was performed using a biotinylated peptide mimicking the phosphorylated ITAM motif of Ig- $\alpha$. Purified protein was analyzed via immunoblotting using anti-pTyr antibodies (upper panel) or phospho-Tyr ${ }^{525 / 526}$ site specific antibodies (middle panel). As control, membrane was reprobed with anti-Syk antibodies (lower panel). Molecular mass protein standard $(\mathrm{kDa})$ is indicated on the left. 
Tyrosine residues 525 and 526 of Syk are known to regulate kinase activity (ZHANG et al., 2000). To test the Dok-3 effect on the phosphorylation of these tyrosines immunoblots were additionally analyzed using phospho-tyrosine-site specific antibodies (middle panel). This approach revealed that in contrast to the overall phosphorylation of Syk, phosphorylation of this motif is not changed significantly in Dok-3 expressing versus $d o k-3^{-/-}$cells (lanes 2 and 4 , respectively).

I could show that the Dok-3/Grb2 complex attenuates the BCR-induced phosphorylation of Syk.

\subsubsection{The Dok-3/Grb2 complex alters BCR-induced Syk phosphorylation in a site- specific manner}

The data described above imply that Dok-3 regulates Syk activity by changing the phosphorylation efficiency. In co-operation with Henning Urlaub (MPI, Göttingen) we are able to employ single phospho-acceptor sites in Syk using SILAC (stable isotope labeling in cell culture; ONG et al., 2002) and ESI Ion-trap mass spectrometry. This method was used to compare phosphorylation efficiency of single Syk tyrosine residues in DT40 cells expressing wild-type Dok-3 versus cells expressing Dok-3 $\mathrm{Y}^{331} \mathrm{~F}$.

In order to have a clean experimental setup I generated a Dok-3/Syk-double-deficient DT40 cell line. As the Syk gene is located on the chicken Z chromosome, only one allele had to be targeted. I designed a construct replacing exons 1 and 2 coding for the first 192 amino acids of Syk, by a bleomycin resistance cassette that was flanked by $2345 \mathrm{bp}$ at the 5'-site and $2258 \mathrm{bp}$ at the 3'-site (figure 4.9 A). This pchSyk-bleo construct was transfected into $d o k-3^{-/}$cells. Transfectands were selected with Bleocin ${ }^{\mathrm{TM}}$ and homologues recombination was checked by PCR (data not shown). A targeted allele was detected in 3 out of 6 Bleocin ${ }^{\mathrm{TM}}$ resistant clones and successful depletion was additionally confirmed by immunoblot analysis of CCLs as well as $\mathrm{Ca}^{2+}$ flux analysis. Immunoblot analysis showed that none of the three clones show a remaining expression of Syk (figure $4.8 \mathrm{~B}$, upper panel, lanes 3-5) in comparison to wild-type and $d o k-3^{-/-}$DT40 cells (lanes 1 and 2). Lysates of $s y k^{-/-}$cells served as control (lane 6). As expected $d o k-3 / s y k^{-/-}$clones did not show BCR-induced $\mathrm{Ca}^{2+}$ flux (figure $4.9 \mathrm{C}$, blue, orange and green lines). 
A
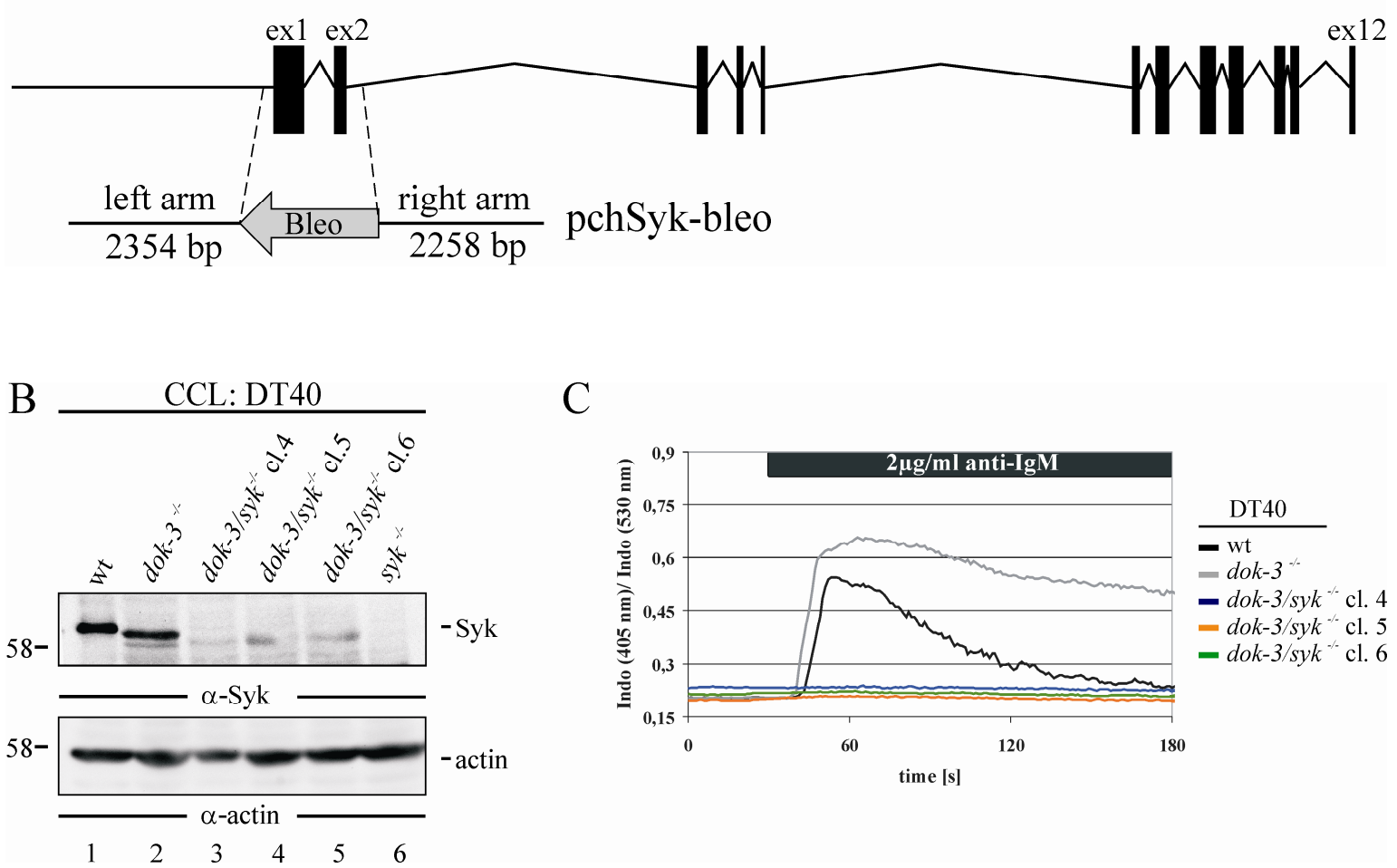

C

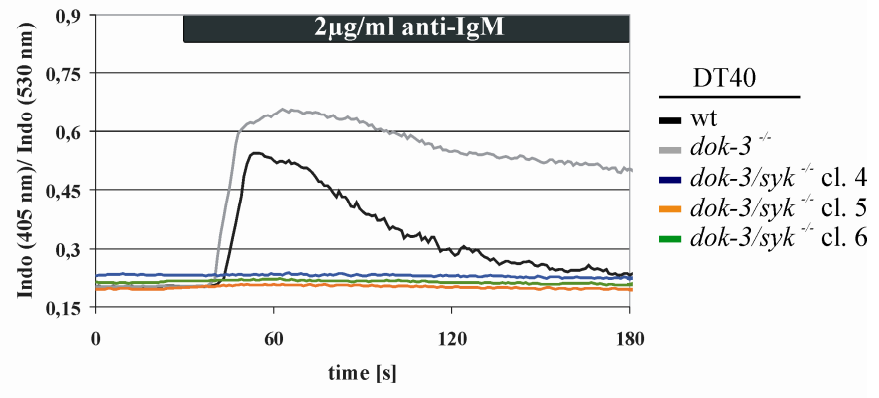

Figure 4.9: Generation of $d o k-3 / s y k^{-/ /}$DT40 B cells

(A) Schematic illustration of the chicken syk genomic locus and the gene targeting strategy. For gene targeting a construct was generated to replace the exons 1 and 2 of the Syk genomic locus by a bleomycin (bleo) resistance. The bleo-cassette was flanked by $2354 \mathrm{bp}$ at the $5^{\prime}$-site and $2258 \mathrm{bp}$ at the 3'-site. (B) Homologues recombination of the pchSyk-bleo into the syk locus was controlled by

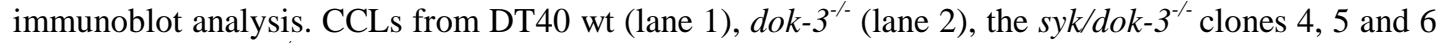
(lanes 3-5) and $\mathrm{syk}^{-/}$cells (lane 6) were analyzed by immunoblotting using anti-Syk antibodies (upper panel). Equal loading was controlled by reprobing the blot with anti-actin antibodies (lower panel). Molecular protein mass standard (kDa) is indicated on the left. (C) Wild-type DT40 (black line), dok$3^{-/-}$(grey line) and $d o k-3 / s y k^{-/}$(clones 4, 5, 6; blue, orange and green lines respectively) cells were loaded with Indo- 1 and $\mathrm{Ca}^{2+}$ flux upon BCR-stimulation was monitored for 3 min by flow cytometry.

I used this Dok-3/Syk-double-deficient cell line to transfect DNA encoding One-STrEPtagged Syk. Subsequently the cells were transfected with DNA encoding either wild-type Dok-3 or the $\mathrm{Y}^{331} \mathrm{~F}$ variant. Cells expressing wild-type Syk and wild-type Dok-3 were grown at least five days in SILAC medium containing 'heavy' isotopes $\left({ }^{2} \mathrm{D}_{4},{ }^{12} \mathrm{C}_{6},{ }^{14} \mathrm{~N}_{2^{-}}\right.$ Lys $;{ }^{13} \mathrm{C}_{6},{ }^{14} \mathrm{~N}_{4}$-Arg), cells expressing wild-type Syk together with Dok-3 $\mathrm{Y}^{331} \mathrm{~F}$ were grown in SILAC medium supplemented with 'light' isotopes $\left({ }^{12} \mathrm{C}_{6},{ }^{14} \mathrm{~N}_{2}\right.$-Lys, ${ }^{12} \mathrm{C}_{6},{ }^{14} \mathrm{~N}_{4}$-Arg). Proteins were purified from lysates of BCR-stimulated cells using a Strep-tactin matrix. After elution purified protein was separated via SDS-PAGE and the band conferring to Syk was subjected to mass spectrometry analysis (figure $4.10 \mathrm{~A}$ ). The ratio of heavy to light peptide abundance correlates with the respective phosphorylation status. Measurements 
revealed that out of five identified phospho-tyrosine motifs only phosphorylation of Syk $\mathrm{Y}^{352}$ was reduced by Dok-3 (figure 4.10 B). While the tyrosine-residues 525, 526, 629 and 630 show a ratio of approximately 1 , resembling similar phosphorylation efficiencies, $\mathrm{Y}^{352}$ shows a ratio of 0.4 , indicating a $60 \%$ reduction in presence of wild-type Dok-3 compared to Dok-3 $\mathrm{Y}^{331} \mathrm{~F}$ expressing cells.

A

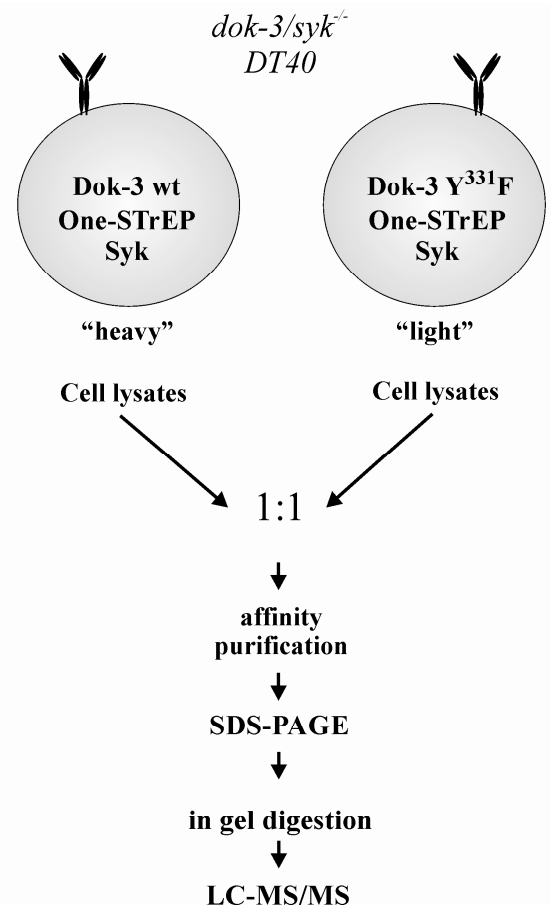

B

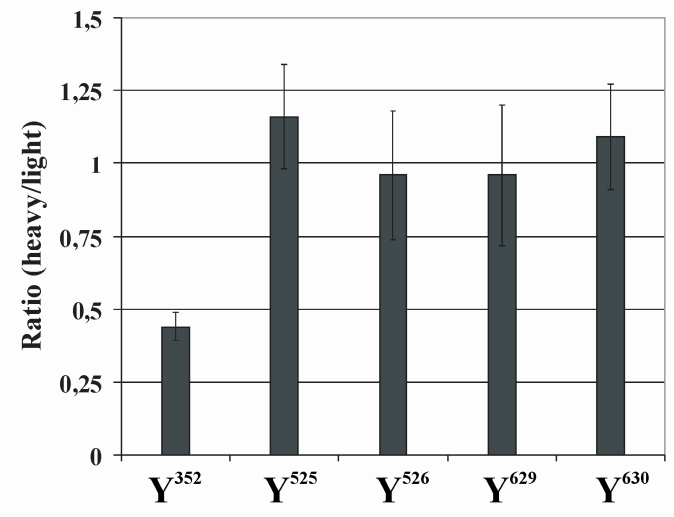

Figure 4.10: $\mathrm{Y}^{352}$ of Syk is less efficiently phosphorylated in Dok-3-expressing cells

(A) Schematic work flow of the affinity purification of Syk (modified from NEUMANN et al., 2011). Cells expressing wild-type Syk-STrEP together with wild-type Dok-3 ("heavy" medium) or the $\mathrm{Y}^{331} \mathrm{~F}$ variant ("light" medium) were stimulated for $3 \mathrm{~min}$. Cellular lysates were pooled and Syk was affinity purified with a Strep-tactin matrix. Protein was eluted and subjected to SDS-PAGE. After coomassie staining the band conferring to Syk was excised, digested and fragments were analyzed by ms ms ESI Trap mass spectrometry. (B) Standard deviation of different identified peptides containing the respective residue.

To prove the mass spectrometry data, I next checked phosphorylation of this specific motif by flow cytometry. Therefore the Dok-3/Syk-double-deficient cells were either reconstituted with Citrin-tagged Syk together with wild-type Dok-3 or the $\mathrm{Y}^{331} \mathrm{~F}$ variant respectively. After stimulation cells were fixed and phospho-Syk was stained using fluorophor-conjugated phospho-Syk $\mathrm{Y}^{352}$ antibodies. Flow cytometry analysis showed that cells expressing the $\mathrm{Y}^{331} \mathrm{~F}$ variant of Dok-3 have significantly stronger signals compared to cells expressing wild-type Dok-3 (figure 4.11). 
A

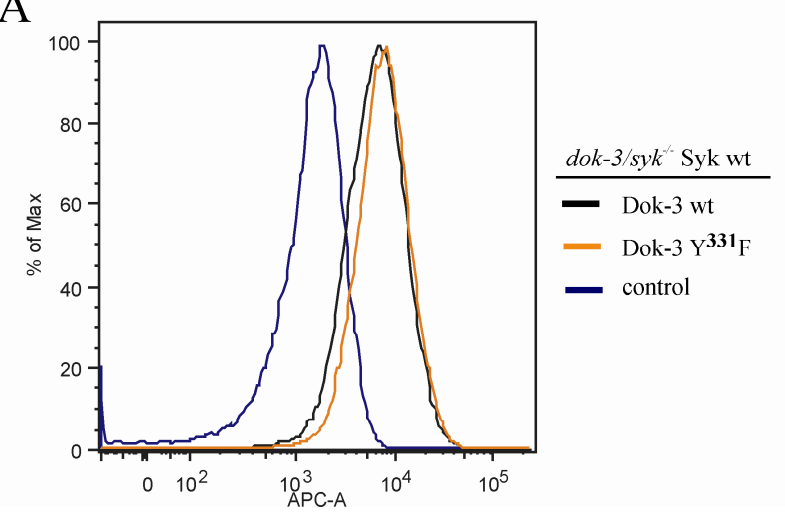

$\mathrm{B}$

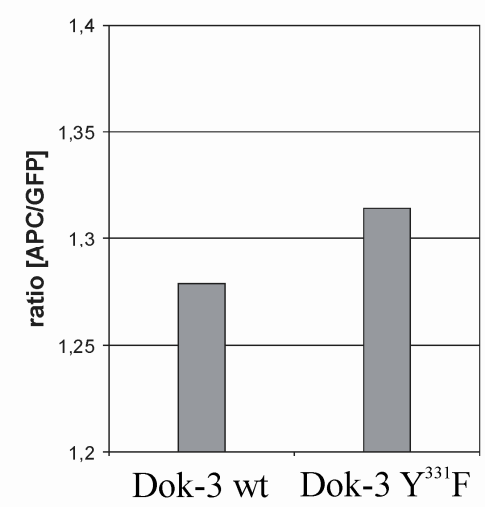

Figure 4.11: Expression of Dok-3 decreases the phosphorylation efficiency of Syk $\mathrm{Y}^{352}$

(A) Dok-3/Syk double deficient cells, expressing Cit-Syk either alone or together with Dok-3 wt or the $\mathrm{Y}^{331} \mathrm{~F}$ variant, were BCR-stimulated for $3 \mathrm{~min}$. Cells were fixed and phosphorylated Syk was stained using Alexa Fluor 647® conjugated anti-phospho Syk $\mathrm{Y}^{352}$ antibodies. 50000 cells were analyzed by flow cytometry. (B) The mean values of the flow cytometry analysis are shown.

\subsubsection{The Dok-3/Grb2 complex reduces the kinase activity of Syk.}

Several studies have shown that the phosphorylation pattern of Syk alters the kinase activity. Tyrosine residue 352 acts together with residue 348 to keep Syk in a "closed" inactive conformation (TSANG et al., 2008, ARIAS-PALOMO et al., 2009). Phosphorylation of these tyrosines disrupts auto-inhibitory interactions, resulting in an open active confirmation. As Dok-3 alters the BCR-induced phosphorylation of $\mathrm{Y}^{352}$, I wanted to test whether Dok-3/Grb2 has an impact on Syk kinase activity, too.

The Dok-3/Syk-double-deficient DT40 cells were first transduced with DNA encoding Citrin-Syk and subsequently transfected with DNA encoding either Dok-3 wt or the Dok-3 $\mathrm{Y}^{331} \mathrm{~F}$ variant. Lysates of BCR-stimulated cells were subjected to anti-GFP immunoprecipitation. For in vitro kinase assay, purified protein was incubated with a biotinylated substrate peptide together with ATP for $30 \mathrm{~min}$. Phosphorylation efficiency of the peptide was analyzed by ELISA using streptavidin-coated 96-well plates and anti-pTyr antibodies. Analysis of four independent experiments unveiled a compromised kinase activity of Syk in presence of Dok-3 compared to control cells expressing the $\mathrm{Y}^{331} \mathrm{~F}$ variant (figure $4.12 \mathrm{~A}$ ). Immunoblot analysis of purified proteins with anti-GFP antibodies showed that similar amounts of Syk were precipitated (figure 4.12 B).

These data show that Dok-3/Grb2 mediated alterations in BCR-induced Sykphosphorylation influence the kinase activity. 
A

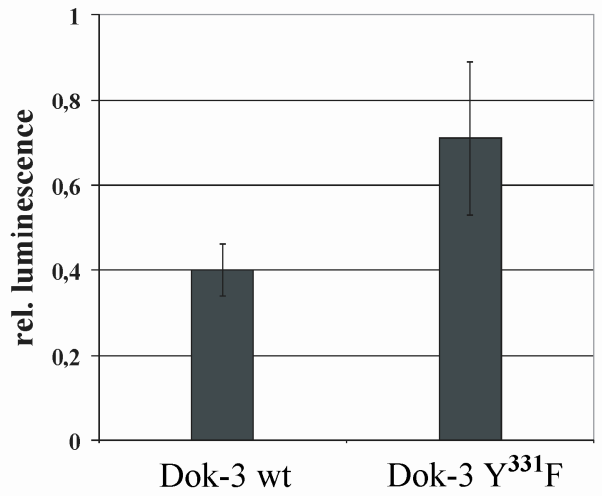

B

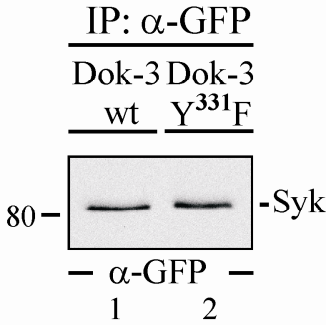

Figure 4.12: Dok-3/Grb2 reduces the kinase activity of Syk in BCR-activated cells

(A) Dok-3/Syk-double-deficient DT40 cells expressing either wild-type Dok-3 or Dok-3 $\mathrm{Y}^{331} \mathrm{~F}$ together with Citrin-tagged Syk were BCR-stimulated for $5 \mathrm{~min}$. Lysates were subjected to anti-GFP immunoprecipitation and purified protein was incubated with the Gastric precursor $\left(\mathrm{Y}^{87}\right)$ biotinylated peptide (CST) and ATP at room temperature for $30 \mathrm{~min}$. Substrate was bound to a streptavidin-coated 96-well plate. ELISA was performed with anti-pTyr and HRPO-conjugated goat-anti-mouse antibodies. Results are shown as mean values \pm s.d. of four independent experiments. (B) Amount of purified proteins was controlled by immunoblot analysis with anti-GFP antibodies. Molecular protein mass standard $(\mathrm{kDa})$ is indicated on the left.

\subsubsection{Dok-3/Grb2 attenuates Lyn-dependent Syk phosphorylation}

Phosphorylation of Syk is mediated by two distinct processes. Beyond the phosphorylation meditated by Lyn, Syk can also be auto-phosphorylated. I next tested, whether the Dok-3 effect is due to an altered auto-phosphorylation of Syk or to an altered Lyn-dependent Syk tyrosine phosphorylation.

For this purpose, I generated a double-deficient DT40 cell line, lacking expression of Lyn and Dok-3. Therefore I used the insertion construct for generation of the $d o k-3^{-/}$cell line (Stork et al., 2007). I replaced the resistance cassettes by DNA either encoding resistance to bleomycin (bleo) or mycophenolic acid (gpt). The pDok-3-bleo construct was transfected into $\mathrm{lyn}^{-/}$cells and homologous recombination was controlled by PCR. A targeted allele was detected in 2 out of 48 Bleocin $^{\mathrm{TM}}$ resistant clones (figure $4.13 \mathrm{~A}$ ). The pDok-3-gpt construct was then transfected into the heterozygous clone 1. Transfectands were selected with Bleocin ${ }^{\mathrm{TM}}$ and mycophenolic acid and homologous recombination was confirmed by PCR again. Both targeted alleles could be detected in 2 out of 17 clones (figure 4.13 A). Successful generation of the double-deficient cell lines was confirmed by 
immunoblot analysis with anti-Dok-3 antibodies (figure $4.13 \mathrm{~B}$ ) showing that the heterozygous clone has a reduced Dok-3 expression (lane 3) in comparison to DT40 wildtype and $l y n^{-1-}$ cells (lanes 1 and 2), while the homozygous clones do not express Dok-3 (lanes 4 and 5). Dok-3-deficient cells served as control (lane 6).

A

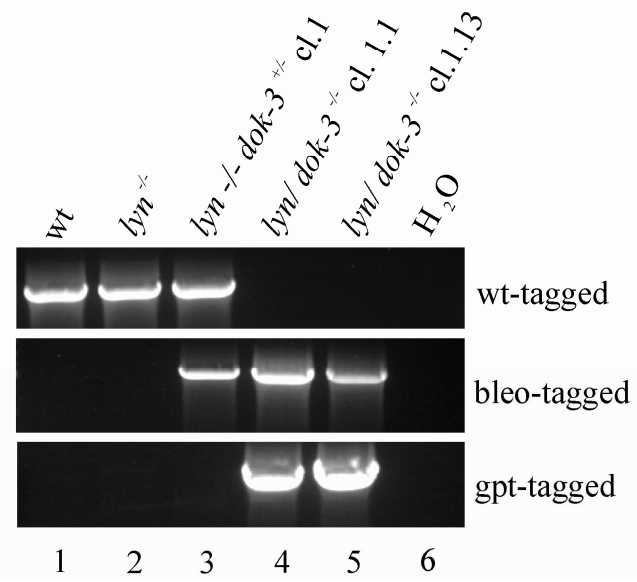

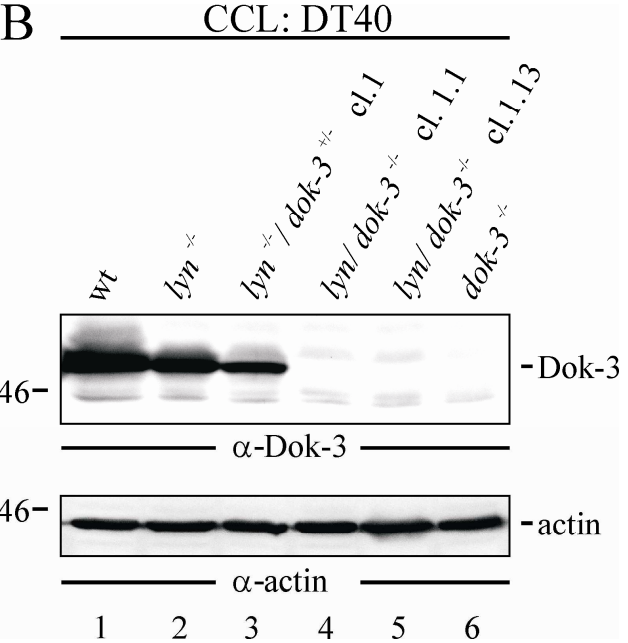

Figure 4.13: Generation of lyn/dok- $3^{-/}$DT40 B cells

For targeting of the dok-3 gene the insertion construct generated by B. Stork was used (STORK et al., 2007). (A) Homologues recombination of the pchDok-bleo (middle panel) and pchDok-gpt (lower panel) into the $d o k-3$ locus was confirmed by PCR. For the wild-type $d o k-3$ allele (upper panel) the oligonucleotides screenLAfor2 and chDok-3rev2 were used. Bleo- and gpt-targeted alleles were amplified using the oligonucleotides screenLAfor2 and bleoA or gpt2, respectively. (B) Cleared cellular lysates from DT40 wt (lane 1), lyn $n^{-/}$(lane 2), the heterozygous clone 1(lane 3), and the homozygous clones 1.1 and 1.13 (lanes 4 and 5) as well as $d o k-3^{-/}$cells (lane 6) were analyzed by immunoblotting using anti-chicken Dok-3 antibodies. Equal loading was controlled by reprobing the blot with anti-actin antibodies. Molecular protein mass standard $(\mathrm{kDa})$ is indicated on the left.

Using retroviral gene transfer constructs encoding wild-type Dok-3 or Dok-3 $\mathrm{Y}^{331} \mathrm{~F}$ were transfected into the $l y n / d o k-3^{--}$clone 1.1. Cells were stimulated via the BCR and Syk was affinity purified from cellular lysates using the Ig- $\alpha$ pITAM-biotinylated peptide. BCRinduced phosphorylation of Syk was analyzed with anti-pTyr antibodies (figure 4.14 A, upper panel) and equal amounts of loaded protein were confirmed using anti-Syk antibodies (A, lower panel). BCR-stimulation increases the phosphorylation of Syk in cells expressing either wild-type Dok-3 or the $\mathrm{Y}^{331} \mathrm{~F}$ variant (A, upper panel, lanes 2 and 4). Compared to Dok-3 $\mathrm{Y}^{331}$ F-expressing cells (lane 4), cells expressing wild-type Dok-3 have a slight increase in Syk phosphorylation level (lane 2). Quantification of three independent experiments proved the observation. Ratios of signal intensities of phospho-Syk versus Syk 
showed an increase of Syk auto-phosphorylation levels in wild-type Dok-3 expressing cells (figure $4.14 \mathrm{~B}$ ).

These data show that Dok-3/Grb2 affects Lyn-dependent Syk-phosphorylation rather than auto-phosphorylation.
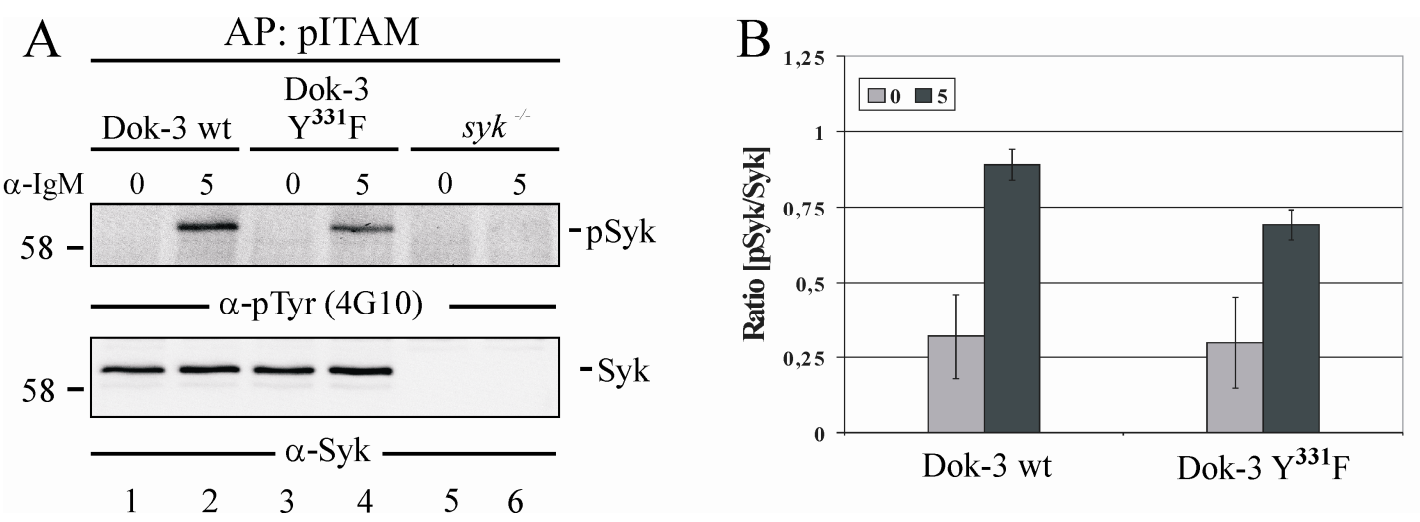

Figure 4.14: Dok-3 does not alter the BCR-induced phosphorylation of Syk in absence of Lyn

(A) Syk was purified from Lyn/Dok-3-double-deficient cells expressing either wild-type Dok-3 (lanes 1 and 2) or Dok-3 Y ${ }^{331} \mathrm{~F}$ (lanes 3 and 4) and, as control, from Syk-deficient cells (lanes 5 and 6). Cells were left untreated (0) or stimulated (5) for $5 \mathrm{~min}$ and lysates were subjected to affinitypurification with biotinylated pITAM peptides. Purified protein was analyzed by SDS-PAGE and immunoblotting with anti-pTyr antibodies (upper panel). Equal protein loading was controlled with anti-Syk antibodies (lower panel). Molecular protein mass standard (kDa) is indicated on the left. (B) Using ImageJ software the ratio of anti-pTyr versus anti-Syk signals was calculated. Results are shown as mean values \pm s.d. for three independent experiments.

Next I wanted to address whether Dok-3/Grb2-dependent signal regulation is restricted to the altered phosphorylation of Syk $\mathrm{Y}^{352}$. Hence, I examined the influence of Dok-3/Grb2 on a Syk variant where both tyrosines $\left(\mathrm{Y}^{348}\right.$ and $\mathrm{Y}^{352}$ ) were substituted for aspartic acid. According to the results shown above phosphorylation of these variant cannot be regulated by Dok-3/Grb2. Therefore $d o k-3 / s y k^{-/}$DT40 cells were transfected with DNA encoding wild-type Syk or the $\mathrm{Y}^{348 / 352} \mathrm{D}$ variant (BRDICKA et al., 2005). Using retroviral gene transfer constructs encoding DNA for wild-type Dok-3 or the $\mathrm{Y}^{331} \mathrm{~F}$ variant were additionally transfected. Cells were loaded with Indo-1 and subjected to flow cytometry analysis. Analysis of the $\mathrm{Ca}^{2+}$ mobilization revealed a decreased $\mathrm{Ca}^{2+}$ flux upon $\mathrm{BCR}$ engagement in cells expressing Syk $\mathrm{Y}^{348 / 352} \mathrm{D}$ in comparison to wild-type Syk expressing cells (figure 4.15, black and blue lines). Moreover, Dok-3 $\mathrm{Y}^{331} \mathrm{~F}$ has a dominant negative effect on the signal, in both, wild-type Syk and the $\mathrm{Y}^{348 / 352} \mathrm{D}$ expressing cells, evident from 
an increased $\mathrm{Ca}^{2+}$ signal (grey and orange lines) in comparison to cells expressing wildtype Dok-3 respectively (black and blue lines).

These data show that Dok-3/Grb2 modulates BCR-induced signaling processes beyond attenuating Syk phosphorylation.

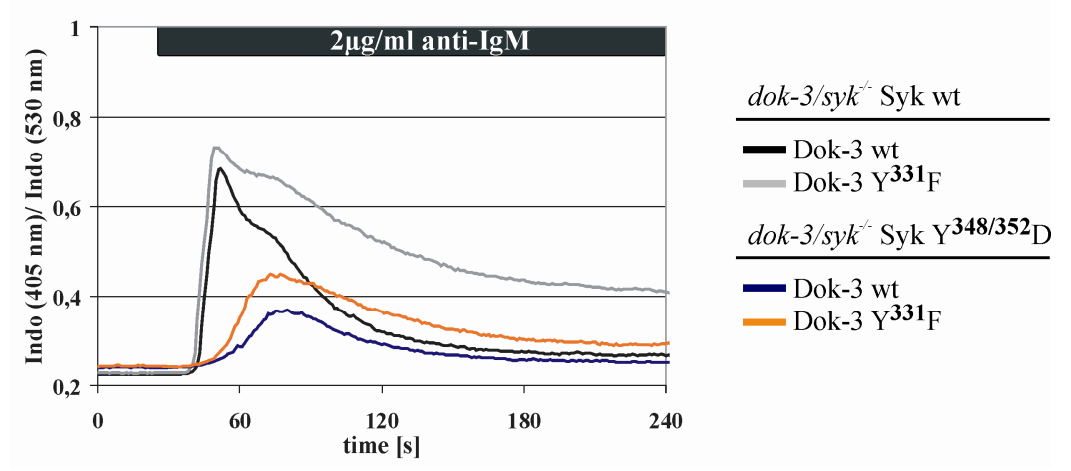

Figure 4.15: Dok-3/Grb2 mediated inhibition is not restricted to alterations in Syk $\mathrm{Y}^{352}$ phosphorylation

Cells expressing either wild-type Syk (black and grey lines) or the $\mathrm{Y}^{348 / 352} \mathrm{D}$ variant (blue and orange lines) together with Dok-3 wt or the $\mathrm{Y}^{331} \mathrm{~F}$ variant were loaded with Indo-1 and $\mathrm{BCR}$ - induced $\mathrm{Ca}^{2+}$ release was monitored for $4 \mathrm{~min}$.

\subsubsection{Dok-3/Grb2 alters the phosphorylation pattern of inhibitory Lyn targets}

As the data described above imply Dok-3/Grb2 functions beyond regulation of Syk activity, I extended the analysis of Lyn targets to other BCR effectors. Lyn is a key regulator of $\mathrm{Ca}^{2+}$ signaling and besides its role in BCR-induced signal initiation it also plays a pivotal role in negative regulation of the BCR signaling. Thus, the impact of Dok-3/Grb2 on the activation of inhibitory Lyn targets was addressed.

\subsubsection{The BCR-induced phosphorylation of SHIP is augmented by Dok-3}

The inositol phosphatase SHIP plays a crucial role in downregulating the BCR-induced $\mathrm{Ca}^{2+}$ signal. Upon receptor activation it is recruited to the membrane where it hydrolyzes $\mathrm{PI}(3,4,5) \mathrm{P}_{3}$ to $\mathrm{PI}(3,4) \mathrm{P}_{2}$ thereby reducing the binding sites for the $\mathrm{PH}$-domains of Btk and PLC- $\gamma 2$. As SHIP is known to be a prominent substrate of Lyn (PHEE et al., 2000), I first wanted to see if the SHIP phosphorylation is modified by Dok-3/Grb2. 
Cleared cellular lysates (CCL) from unstimulated and BCR-stimulated $d o k-3^{-/}$, wild-type Dok-3 reconstituted, and ship $^{-/}$cells were analyzed by anti-SHIP immunoblotting using antibodies directed against phosphorylated $\mathrm{Y}^{1020}$ of SHIP (figure $4.16 \mathrm{~A}$, upper panel). Equal amounts of protein loading were controlled using anti-actin antibodies (A, lower panel). Analysis revealed that phosphorylation of SHIP increases upon BCR stimulation (A, upper panel, lanes 2 and 4) and that this increase is more pronounced in Dok-3 expressing cells (lane 2) compared to Dok-3-deficient cells (lane 4). Quantification of three independent experiments proved the observation. Ratios of signal intensities of phosphoSHIP $\left(\mathrm{Y}^{1020}\right)$ versus actin showed an increase of SHIP phosphorylation levels in wild-type Dok-3 expressing cells compared to Dok-3-deficient control cells (figure 4.16 B). Error bars reflect mean values \pm standard deviation.
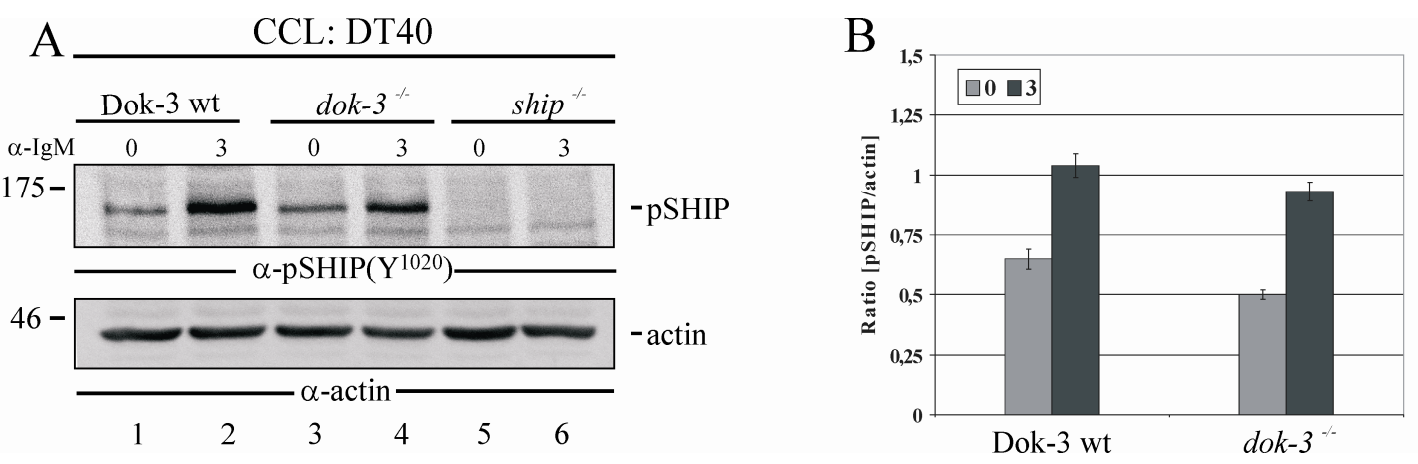

Figure 4.16: Dok-3 expression leads to an increase of SHIP phosphorylation

(A) Wild-type Dok-3 expressing (lanes 1 and 2), dok-3-/ (lanes 3 and 4), and ship $p^{-/}$cells (lanes 5 and 6) were left untreated (0) or stimulated (3) via the BCR. CCLs were subjected to SDS-PAGE and phosphorylation was detected via immunoblotting with antibodies detecting phosphorylated $\mathrm{Y}^{1020}$ of SHIP (upper panel). Equal purification and loading were controlled using anti-actin antibodies (lower panel). Molecular mass protein standards (kDa) are indicated on the left. (B) Using ImageJ software the ratio of anti-pY ${ }^{1020}$ versus anti-actin was defined. Results are shown as mean values \pm s.d. for three independent experiments.

\subsubsection{Dok-3 does not alter the BCR-induced SHP-1 phosphorylation}

SHP-1 belongs to the subfamily of non-transmembrane SH2 domain containing protein tyrosine phosphatases (PTP). It is known to modify B cell activation by dephosphorylation of specific tyrosines of signaling effectors like SLP-65, Vav or Syk (KON-KOZLOWSKI et al., 1996). I next wanted to test the influence of Dok-3/Grb2 on the tyrosine phosphorylation of this phosphatase. 
DNA encoding for GFP-tagged SHP-1 was retrovirally transduced into $d o k-3^{-/}$and wildtype Dok-3 reconstituted DT40 cells. Anti-GFP immunoprecipitation was performed from lysates of unstimulated and BCR-stimulated cells and samples were subjected to immunoblot analysis using anti-pTyr antibodies (figure $4.17 \mathrm{~A}$, upper panel). Equal amounts of purified protein were controlled using anti-GFP antibodies (A, lower panel). The data show that SHP-1 is already phosphorylated in resting cells and that upon BCR engagement the phosphorylation is slightly increased (A, upper panel, lanes 1-4). Further it could be shown that the phosphorylation is similar in cells expressing Dok-3 (lanes 1 and 2) compared to cells that are Dok-3 deficient (lanes 3 and 4). Quantification of three independent experiments verified the observation. Ratios of signal intensities of phosphoSHP-1 versus GFP confirm that the tyrosine phosphorylation of SHP-1 is not altered by Dok-3 (figure $4.17 \mathrm{~B}$ ). Error bars reflect mean values \pm standard deviation.
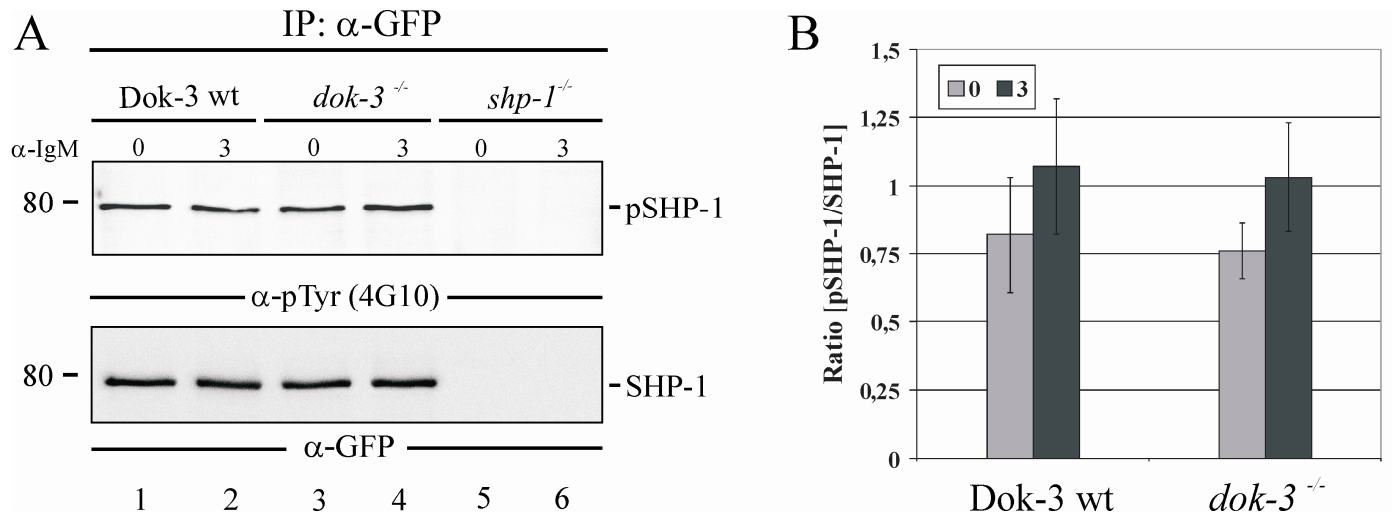

\begin{abstract}
Figure 4.17: Dok-3 does not alter the BCR-induced SHP-1 phosphorylation
(A) Dok-3-deficient cells expressing either GFP-SHP-1 alone (lanes 3 and 4) or together with wildtype Dok-3 (lanes 1 and 2 ) as well as shp- $1^{-/}$cells (lanes 5 and 6 ) were left untreated (0) or stimulated (3) via the BCR for 3 min. Lysates were subjected to anti-GFP-immunoprecipitation. Samples were subjected to SDS-PAGE and tyrosine phosphorylation was detected using anti-pTyr immunoblotting (upper panel). Equal protein purification and loading were controlled using anti-GFP antibodies (lower panel). Molecular mass protein standards $(\mathrm{kDa})$ are indicated on the left. (B) Calculated ratio of anti-pTyr versus anti-GFP signals was defined using ImageJ software. Results are shown as mean values \pm s.d. for three independent experiments.
\end{abstract}

\title{
4.2.3.3 Dok-3 promotes the BCR-induced phosphorylation of SHP-2
}

SHP-2 belongs to the family of non-transmembrane PTPs but its precise role in BCR signaling is not well understood to date.

Lysates from unstimulated and BCR-stimulated Dok-3-deficient, wild-type Dok-3 expressing and SHP-2-deficient DT40 cells were subjected to immunoprecipitation with 
anti-SHP-2 antibodies. Purified proteins were analyzed by anti-pTyr immunoblotting (figure $4.18 \mathrm{~A}$, upper panel). Equal amounts of protein were controlled using anti-SHP-2 antibodies (A, lower panel). SHP-2 is already phosphorylated in resting cells (figure 4.18 A, upper panel, lanes 1 and 3) and BCR-engagement induces phosphorylation of SHP-2 in cells expressing wild-type Dok-3 (lane 2) while SHP-2 phosphorylation was not altered by BCR-engagement in Dok-3-deficient cells (lane 4). This observation was confirmed by densitometric quantification of three independent experiments (figure $4.18 \mathrm{~B}$ ). Ratios of signal intensities of phospho-SHP-2 versus SHP-2 validate that the BCR-induced tyrosine phosphorylation of SHP-2 requires the Dok-3/Grb2 complex. Error bars reflect mean values \pm standard deviation.
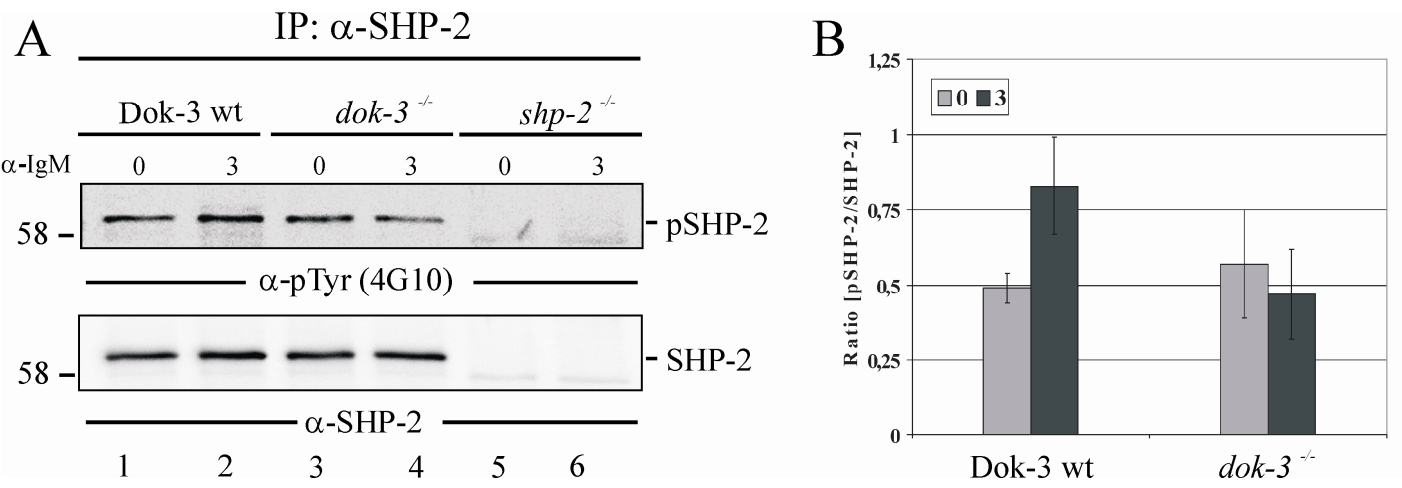

\begin{abstract}
Figure 4.18: The BCR-induced SHP-2 phosphorylation requires Dok-3
(A) Cellular lysates from unstimulated (0) and BCR stimulated (3) wild-type Dok-3 expressing (lanes 1 and 2), dok- $3^{-\alpha}$ (lanes 3 and 4) and $\operatorname{shp}-2^{-\alpha}$ (lanes 5 and 6) cells were subjected to immunoprecipitation with anti-SHP-2 antibodies. Purified SHP-2 was subjected to SDS-PAGE and phosphorylation was detected with anti-pTyr-immunoblotting (upper panel). Equal protein purification and loading were controlled with anti-SHP-2 antibodies (lower panel). Molecular mass protein standard $(\mathrm{kDa})$ is indicated on the left. (B) Using ImageJ software ratios of anti-pTyr versus anti-SHP-2 signals were calculated. Results are shown as mean values \pm s.d. for three independent experiments.
\end{abstract}

\title{
4.2.3.4 The BCR-induced phosphorylation of c-Cbl is not altered by Dok-3
}

The ubiquitin ligases of the Casitas B lineage lymphoma ( $\mathrm{Cbl}$ ) family were shown to regulate signaling of a multiplicity of receptors. Two members of the family, c-Cbl and Cbl-b, are expressed in B cells and have been shown to be integrated in the BCR-signaling cascade and to regulate PLC- $\gamma 2$ activation and $\mathrm{Ca}^{2+}$ response. Hence, I analyzed the impact of Dok-3 on the tyrosine phosphorylation of c-Cbl. 
Wild-type Dok-3 reconstituted, $d o k-3^{-/}$and $c b l^{--}$DT40 cells were either stimulated via the BCR for 3 min or left untreated. Lysates were subjected to immunoprecipitation with antic-Cbl antibodies and purified protein was analyzed by immunoblotting using anti-pTyr antibodies (figure 4.19 A, upper panel). Analysis with anti-c-Cbl antibodies revealed equal amounts of purification and loading (lower panel). Phosphorylation of c-Cbl is evident in stimulated cells (upper panel, lane 2 and 4). Immunoblot analysis revealed a slightly higher level of phosphorylation in cells that are Dok-3-deficient (lane 4) compared to Dok-3 expressing cells (lane 2). Quantification of three independent experiments and ratios of signal intensities of phospho-c-Cbl versus c-Cbl (figure 4.19 B) hence, unveil that Dok-3 dependent decrease of BCR-induced c-Cbl phosphorylation is statistically not significant. Error bars reflect mean values \pm standard deviation.

A

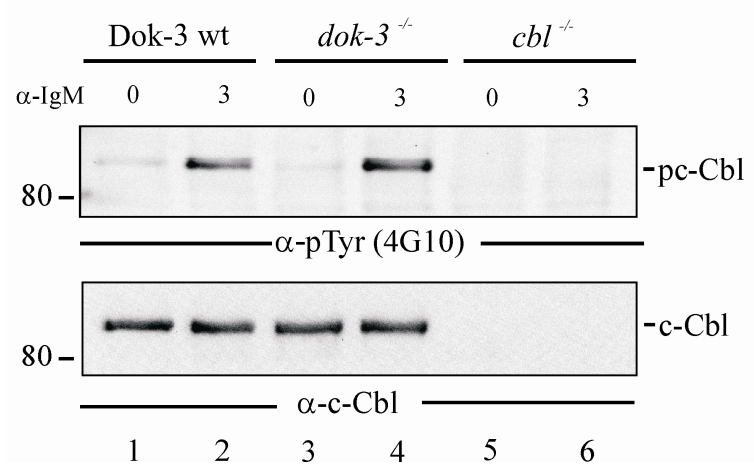

B

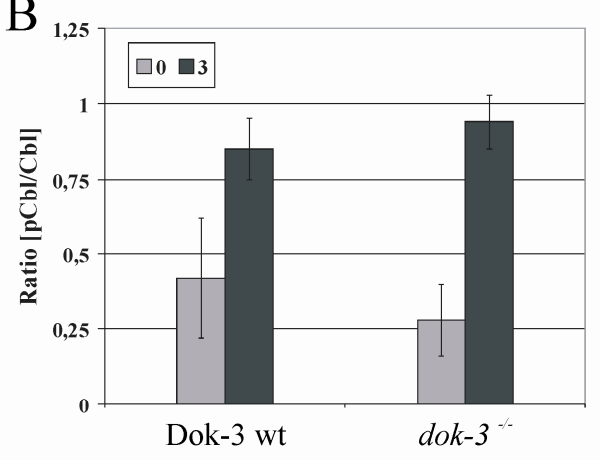

Figure 4.19: Dok-3/Grb2 does not alter BCR-induced Cbl phosphorylation

(A) Dok-3 wt expressing (lanes 1 and 2), $d o k-3^{-/}$(lanes 3 and 4) and $c b t^{-/}$(Lanes 5 and 6) cells were left untreated (0) or stimulated (3) via the BCR for 3 min. Lysates were subjected to anti-c-Cbl immunoprecipitation. Samples were subjected to SDS-PAGE and phosphorylation was detected via immunoblotting with anti-pTyr-antibodies (upper panel). Equal protein purification and loading was controlled by reprobing the membrane with anti-c-Cbl antibodies (lower panel). Molecular mass protein standard $(\mathrm{kDa})$ is indicated on the left. (B) Using ImageJ software ratios of anti-pTyr versus anti-cCbl signals were calculated. Results are shown as mean values \pm s.d. for three independent experiments. 


\subsubsection{Lyn is required for the Dok-3/Grb2 dependent signal inhibition}

Lyn is the only Src family kinase expressed in DT40 cells. It is the very proximal PTK in the BCR signaling cascade initiating a complex network of phosphorylation. As I could show in this thesis that the phosphorylation of several Lyn targets is altered by Dok-3, the question was addressed whether Dok-3/Grb2 directly regulates the kinase activity of Lyn.

\subsubsection{The BCR-induced Lyn-phosphorylation is not altered by Dok-3/Grb2}

Phosphorylation is a key modulator of kinase activity and it has been shown that Src family kinases like Lyn encompass activatory and inhibitory tyrosine residues (COOPER and HOWELL, 1993). Hence, I examined the efficiency of BCR-induced Lynphosphorylation in dependence of Dok-3 expression.

Lyn/Dok-3-double-deficient cells, expressing HA-tagged wild-type Lyn, were retrovirally transduced with DNA encoding either wild-type Dok-3 or the $\mathrm{Y}^{331} \mathrm{~F}$ variant. Lysates from unstimulated and stimulated cells were subjected to immunoprecipitation with anti-HA antibodies. The phosphorylation status of Lyn was analyzed using anti-pTyr antibodies (figure 4.20 A, upper panel) or phospho-tyrosine specific antibodies detecting either the activatory $\mathrm{Y}^{397}$ (anti-pSrc $\mathrm{Y}^{416}$, second panel) or the inhibitory $\mathrm{Y}^{507}$ (third panel). Equal protein loading was confirmed by anti-HA immunoblot (fourth panel).

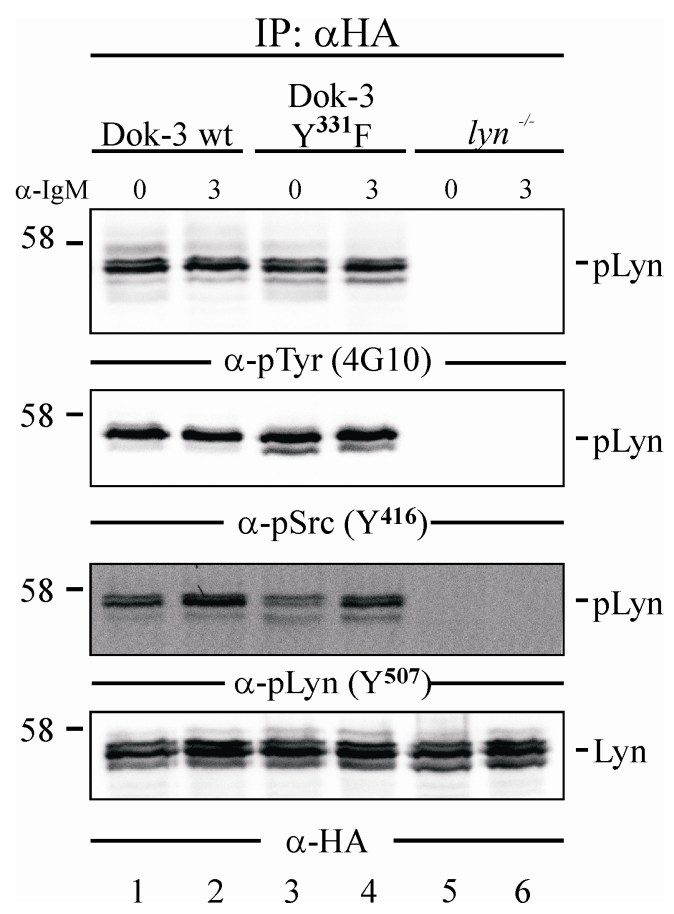

Figure 4.20: Dok-3/Grb2 does not significantly alter BCR-induced Lyn phosphorylation

Lyn/Dok-3-double-deficient cells expressing wild-type Dok-3 (lanes 1 and 2) or Dok-3 $\mathrm{Y}^{331} \mathrm{~F}$ (lanes 3 and 4) together with HA-tagged wildtype Lyn HA and, as control, lyn/dok $-3^{-/-}$cells only reconstituted with wild-type Dok-3 (lanes 5 and 6 ; termed as $l y n^{-/}$) were left untreated (0) or BCR-stimulated (3) for $3 \mathrm{~min}$. Cellular lysates were subjected to anti-HA immunoprecipitation and purified protein was analyzed via immunoblotting using anti-pTyr (upper panel), anti-pSrc $\left(\mathrm{Y}^{416}\right)\left(\mathrm{Y}^{397}\right.$ in Lyn, second panel) or anti-pLyn $\left(\mathrm{Y}^{507}\right)$ (third panel) antibodies. As control, blots were analyzed with anti-HA antibodies (lower panel). Molecular mass protein standard $(\mathrm{kDa})$ is indicated on the left. 
Both cell lines show a slight BCR-induced increase of Lyn phosphorylation (upper panel, lanes 2 and 4). Phosphorylation of tyrosine residue 397 is hardly inducible by BCR engagement (second panel, lanes 1-4). In cells expressing wild-type Dok-3, Y ${ }^{397}$ phosphorylation is marginally reduced compared to Dok-3 $\mathrm{Y}^{331} \mathrm{~F}$ expressing cells. In contrast, wild-type Dok-3 expression slightly increases the BCR-induced phosphorylation of $\mathrm{Y}^{507}$ (third panel, lanes 2 and 4).

Altogether, data show that Lyn phosphorylation is hardly altered by Dok-3/Grb2.

\subsubsection{Dok-3/Grb2 does not influence the Lyn kinase activity}

Knowing that Dok-3 does not alter Lyn phosphorylation I next tested whether Lyn kinase activity is modulated by Dok-3/Grb2.

Transfectands described above were used to perform an in vitro kinase assay. Lysates of BCR-stimulated cells were subjected to anti-HA immunoprecipitation and purified protein was incubated with a biotin-conjugated substrate peptide and ATP for $15 \mathrm{~min}$. After immobilizing the peptide to a streptavidin-coated 96-well plate, phosphorylation efficiency was analyzed by ELISA with anti-pTyr antibodies. Mean values \pm standard deviation of four independent experiments (figure $4.21 \mathrm{~A}$ ) showed similar kinase activities in cells expressing wild-type Dok-3 compared to cells expressing the Dok-3 $\mathrm{Y}^{331} \mathrm{~F}$. Equal protein amounts were confirmed by anti-HA immunoblotting (figure $4.21 \mathrm{~B}$ ).
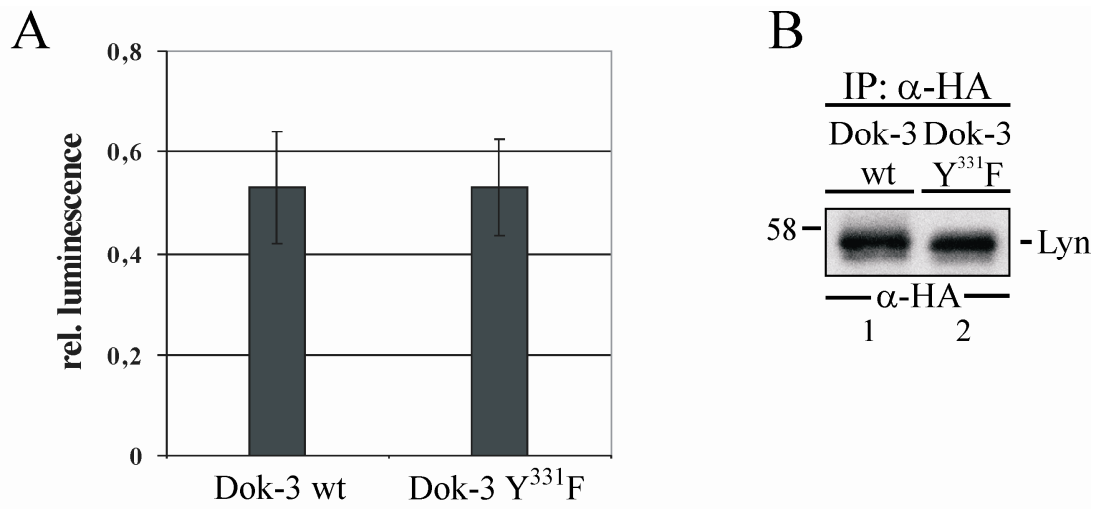

Figure 4.21: Dok-3 does not influence the kinase activity of Lyn

(A) For in vitro kinase assay lyn/dok-3 $3^{-/-}$cells expressing HA-tagged Lyn together with wild-type Dok-3 or Dok-3 $\mathrm{Y}^{331} \mathrm{~F}$ were stimulated for $3 \mathrm{~min}$ and subjected to anti-HA immunoprecipitation. Purified protein was incubated with the signal transduction biotinylated peptide (CST) and ATP at room temperature for $15 \mathrm{~min}$. Substrate was immobilized on a streptavidin-coated 96-well plate. ELISA was then performed with anti-pTyr and HRPO-conjugated goat-anti-mouse antibodies. Results are shown as mean values \pm s.d. for four independent experiments. (B) Amount of precipitated proteins was controlled by anti-GFP immunoblot analysis. Molecular mass protein standard (kDa) is indicated on the left. 


\subsubsection{Dok-3/Grb2 mediated negative regulation is depending on Lyn}

Studying Dok-3/Grb2 mediated regulation of Lyn-dependent processes harbors the obvious problem that Dok-3 phosphorylation and hence Dok-3/Grb2 complex formation is Lyndependent. To circumvent this obstacle and to analyze the Dok-3/Grb2 complex function I. Goldbeck generated a chimeric protein comprising the C-terminal SH3 domain of Grb2 fused to the first 322 amino acids of Dok-3 (Dok-3-cSH3) (figure 4.22 A). We further substituted the tyrosine-residues at position 140 and 307 for phenylalanine (Dok-3YYFFcSH3) to make the protein completely independent of Lyn-mediated phosphorylation.

Dok-3-deficient cells where either reconstituted with wild-type Dok-3-GFP, GFP-tagged Dok-3-cSH3 or Dok-3YYFF-cSH3 (figure 4.22 A) to test the functionality of the chimera. $\mathrm{Ca}^{2+}$ flux analysis of these cells revealed that compared to wild-type Dok-3 expressing cells, Dok-3-cSH3 expressing cells show similar profiles of $\mathrm{Ca}^{2+}$ mobilization (figure 4.22 $\mathrm{B}$, black and orange lines). Cells expressing the Dok-3YYFF-cSH3 variant mount a more robust BCR-induced $\mathrm{Ca}^{2+}$ mobilization (blue line) that is however still significantly reduced compared to $d o k-3^{--}$cells (grey line).

A

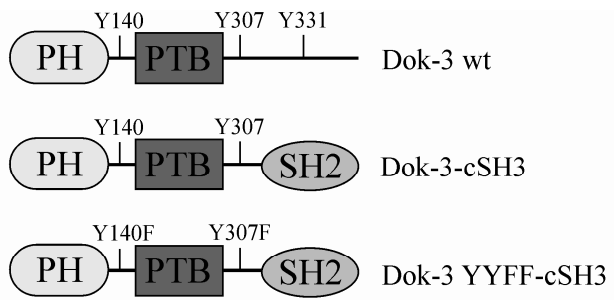

$\mathrm{B}$

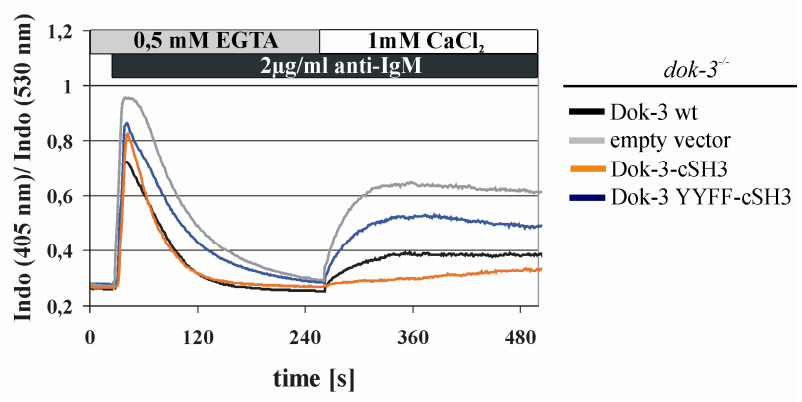

Figure 4.22: The 'Lyn-independent' chimeric Dok-3YYFF-cSH3 protein reconstitutes Dok-3/Grb2 mediated $\mathrm{Ca}^{2+}$ inhibition with reduced efficiency.

(A) The C-terminal SH3 domain of Grb2 was fused to the N-terminal part of Dok-3 (amino acids 1322) thus replacing the $\mathrm{C}$-terminal part, including the $\mathrm{Y}^{331}$, which is crucial for the binding of Grb2 (middle panel). Additionally, $\mathrm{Y}^{140}$ and $\mathrm{Y}^{307}$ were substituted for Phenylalanine (lower panel). (B) Dok-3-deficient cells were either reconstituted with wild-type Dok-3 (black line), the 'wild-type' chimera (Dok-3-cSH3; orange line), the chimera with all tyrosines exchanged to phenylalanines (Dok-3YYFF-cSH3; blue line) or empty vector as control (grey line). Cells were loaded with Indo-1 and BCR induced $\mathrm{Ca}^{2+}$ release from intracellular stores was measured for 4 min in presence of 0.5 mM EGTA. Extracellular $\mathrm{Ca}^{2+}$ concentration was restored to $1 \mathrm{mM}$ and $\mathrm{Ca}^{2+}$ flux over the plasma membrane was monitored for another $4 \mathrm{~min}$.

The tyrosines 140 and 307 have been shown to de dispensable for Dok-3 function. Moreover, it was shown that phsopho- $\mathrm{Y}^{140}$ constitutes a binding motif for the Dok-3 PTB domain allowing for oligomerization of Dok-3 proteins. The different efficiency in 
reconstitutive Dok-3 function of Dok-3-cSH3 and Dok-3YYFF-cSH3 might be due to different abilities to oligomerize.

Dok-3-deficient cells, reconstituted with HA-tagged wild-type Dok-3 were additionally transduced with DNA either encoding the GFP-bound chimeric proteins, described above, or the wild-type Dok-3 protein. HA Dok-3 was purified from lysates of unstimulated and stimulated cells using HA-antibodies. Purified proteins were subjected to immunoblot analysis with anti-GFP and anti-HA antibodies (figure 4.23). Analysis revealed that GFPDok-3 is already co-precipitated with its HA-tagged equivalent in unstimulated cells (figure 4.23 C, upper panel, lane 1). This association increases upon BCR engagement (lane 2). The same could be observed when HA-tagged Dok-3 is co-expressed with Dok-3cSH3 (lanes 3 and 4). In contrast I observed a loss of this interaction in cells expressing the Dok-3YYFF-cSH3 together with Dok-3 (lanes 5 and 6). Detection with anti-HA antibodies confirmed equal amounts of purified wild-type Dok-3 (lower panel). Similar expression of GFP-bound proteins was controlled by anti-GFP immunoblotting of the CCLs (data not shown).

From this data it appears that, although being not essential for Dok-3 function, the oligomerization seems to support the inhibitory effect of the Dok-3/Grb2 complex.

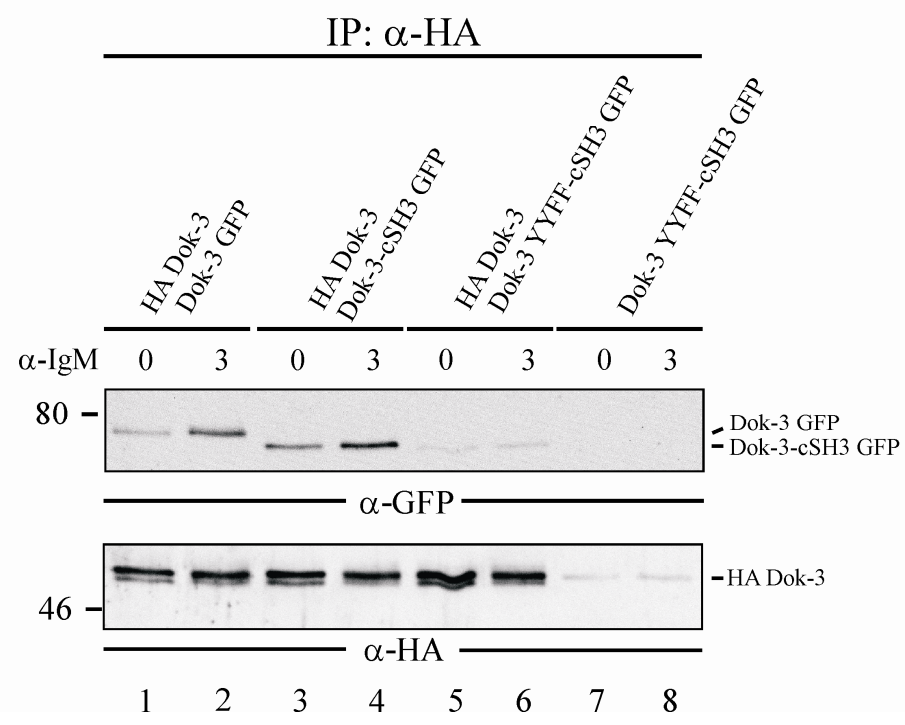

Figure 4.23: The 'Lyn-independent' chimeric Dok-3YYFF-cSH3 protein cannot form homooligomers.

Using retroviral gene transfer $d o k-3^{-/}$cells, previously transfected with DNA encoding HA-tagged wild-type Dok-3, were transduced with DNA encoding either for the GFP-bound wild-type Dok-3 (lanes 1 and 2) or the chimeric proteins Dok-3-cSH3 (lanes 3 and 4) and Dok-3YYFF-cSH3 (lanes 5 and 6). As control, dok- $3^{-/}$only expressing the Dok-3YYFF-cSH3-GFP chimera (lanes 7 and 8) were used. Cells were left untreated (0) or BCR- stimulated (3) and lysates were subjected to anti-HA immunoprecipitation. Proteins were analyzed using anti-GFP (upper panel) and anti-HA (lower panel) antibodies. Molecular mass protein standard $(\mathrm{kDa})$ is indicated on the left. 
To test Dok-3/Grb2 function in absence of Lyn I transduced either Dok-3YYFF-cSH3 or the non-functional Dok-3YYFF-cSH3 $\left[\mathrm{W}^{193} \mathrm{~K}\right]$ variant into Lyn/Dok-3-double-deficient cells previously transfected with DNA encoding wild-type Lyn (figure $4.24 \mathrm{~A}$ ). Cells expressing Dok-3YYFF-cSH3 have a reduced $\mathrm{Ca}^{2+}$ response (black line) in comparison to control cells expressing the non-functional variant (grey line). In contrast, absence of Lyn in the double-deficient cells abrogates the inhibitory function of the chimera (figure 4.24 B). Cell expressing the wild-type chimera (black line) or the non-functional chimera (grey line) had comparable profiles of $\mathrm{Ca}^{2+}$ mobilization. The delay in $\mathrm{Ca}^{2+}$ response in $l y n / d o k-3^{-/-}$cells is due to a delayed Syk activation that is observed in $l y n^{-/}$cells (TAKATA et al., 1994).,

These experiments proofed that Lyn is not only necessary for Dok-3 phosphorylation but is utilized by Dok-3/Grb2 to attenuate efficiency of $\mathrm{Ca}^{2+}$ mobilizing enzymes.
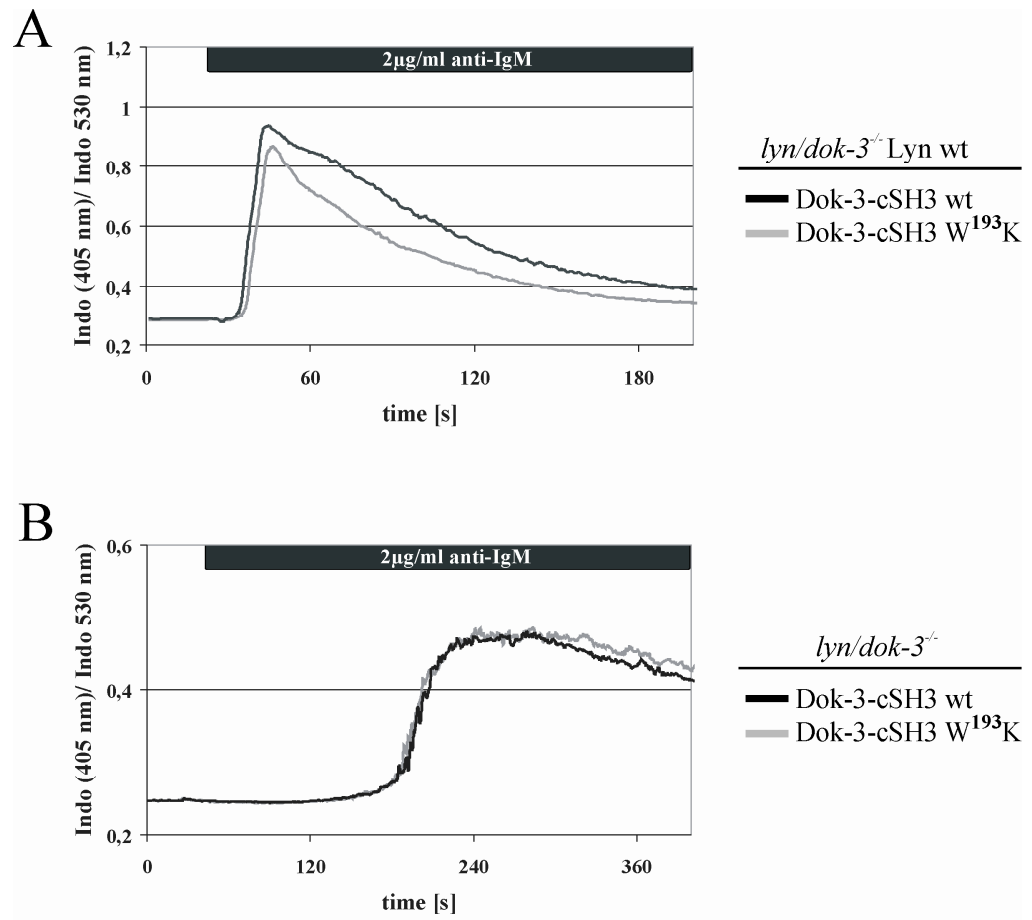

Fig. 4.24: Expression of Lyn is obligatory for the inhibitory effect of the Dok-3/Grb2 chimera

(A) Wild-type Lyn reconstituted Lyn/Dok-3 double deficient cells (lyn/dok-3-1 Lyn wt) were either transduced with DNA encoding the wild-type chimera (Dok-3-cSH3 wt) or a variant with a dominant negative amino acid exchange inside of the SH3 domain (Dok-3-cSH3 $\mathrm{W}^{193} \mathrm{~K}$ ). Cells were loaded with Indo- 1 and $\mathrm{Ca}^{2+}$ released was monitored upon BCR stimulation for 200 sec. (B) DNA encoding for the chimeras was retrovirally transfected into lyn/dok- $3^{--}$cells and $\mathrm{Ca}^{2+}$ release upon BCRstimulation was measured for $400 \mathrm{sec}$. 
Collectively these data unveil the molecular details of Dok-3/Grb2 function. BCRengagement leads to Lyn-dependent phosphorylation of Dok-3 and subsequent Dok-3/Grb2 complex formation. Dok-3/Grb2 complexes are translocated into BCR microsignalosomes where they modulate the balance of activatory and inhibitory Lyn functions leading to reduced activation of Syk and increased integration of SHIP and SHP-2. 


\section{Discussion}

B cells produce antibodies and hence provide adaptive humoral immunity. Activation and differentiation of B cells are strictly controlled by their antigen-receptor (BCR). Depending on the developmental status BCR signals lead to anergy and apoptosis or activation and differentiation. Therefore, BCR signals need to be exactly regulated to keep immunological tolerance without perturbing humoral immunity.

Differential BCR signaling is obvious from different $\mathrm{BCR}$-induced $\mathrm{Ca}^{2+}$ mobilization. Immature B cells that undergo apoptosis in response to antigen-recognition mount weak $\mathrm{Ca}^{2+}$ signals, whereas mature $\mathrm{B}$ cells that are activated by $\mathrm{BCR}$ signals have robust $\mathrm{Ca}^{2+}$ responses. One mandatory factor for generating differential $\mathrm{Ca}^{2+}$ signals is the subcellular distribution of Grb2. This protein has been shown to modulate the intra- and extracellular $\mathrm{Ca}^{2+}$ flux of $\mathrm{B}$ lymphocytes by alternative binding to either the plasma membraneassociated adaptor protein Dok-3 or the transmembrane adaptor LATII. LATII is differentially expressed in B cells and while Grb2-recruitment by Dok-3 inhibits BCRinduced $\mathrm{Ca}^{2+}$ mobilization, binding to LATII prevents this function (STORK et al., 2004; STORK et al., 2007). Analysis in DT40 B cells revealed that upon BCR engagement Dok-3/Grb2 complexes are formed and decrease the production of the second messenger $\mathrm{IP}_{3}$ by modifying the phosphorylation status and activity of PLC- $\gamma 2$. Despite the putative importance of Dok-3/Grb2 for differential $\mathrm{Ca}^{2+}$ signals and its contribution to keep the balance between humoral immunity and immunological tolerance, the molecular details of Dok-3/Grb2 mediated inhibition of BCR-signals are poorly understood. The objective of this work was to reveal these molecular details of Dok-3/Grb2 complex formation and function.

Within this thesis, it was shown that Grb2 translocates Dok-3/Grb2 into areas of BCR microcluster and that this translocation is mandatory for efficient phosphorylation of Dok-3. The process is mediated by the interaction of the C-terminal SH3 domain of Grb2 with Vav3 and/or SLP-65.

Once located in these areas, several lines of evidence show that Dok-3/Grb2 shifts the balance of Lyn-mediated activatory and inhibitory processes towards negative regulators. First, the Lyn-mediated phosphorylation and activation of Syk is attenuated by Dok-3/Grb2, and, second, the phosphorylation of the negative regulators SHIP and SHP-2 is increased. 


\subsection{Association of Grb2 and Dok-3 translocates this protein complex into BCR microsignalosomes.}

It has been shown that recruitment of Grb2 to plasma membrane-associated Dok-3 is essential for negative regulation of BCR signals. This process requires Lyn-dependent phosphorylation of tyrosine residue 331 of Dok-3, which provides a docking site for the Grb2-SH2 domain. Notably, the efficient Dok-3 phosphorylation that is essential for Grb2 association is markedly increased after binding to Grb2 (STORK et al., 2007), leaving the molecular details of the Dok-3/Grb2 interplay unclear.

This thesis elucidates the functional consequences of Dok-3/Grb2 association. Upon BCR engagement Dok-3 becomes phosphorylated and provides a binding site for Grb2, which is thereby recruited to the plasma membrane. This complex then is translocated into areas of BCR microcluster by virtue of the C-terminal SH3 domain of Grb2. Formation of BCR microcluster is a process that is independent of BCR-induced signaling and tends to be formed as a result of diffusion trapping (DEPOIL et al., 2008). Nonetheless it provides a structural basis for the organization of the BCR signaling cascade. Several studies show that upon BCR-engagement signaling effectors like Lyn, SLP-65, Syk, Vav and PLC- $\gamma 2$ accumulate at the areas of BCR microcluster which are thus referred to as 'microsignalosomes' (DEPOIL et al., 2008; WEBER et al., 2008; SOHN et al., 2008). Although the formation and composition of microcluster and microsignalosomes currently remain unclear, several studies give evidence that they are spatial platforms for BCRsignaling and that translocation into these areas appears to be essential to participate in signaling.

Results presented in this thesis demonstrate that Dok-3/Grb2 is associated with microsignalosomes. It was shown that the Grb2-SH3 domain is indirectly associated with the microsignalosomal resident Lyn and this association increases upon BCR engagement. Src kinases like Lyn are not only accumulated in BCR microsignalosomes but have been shown to associate within unligated BCR complexes in resting cells (SOHN et al., 2008; WEBER et al., 2008;: PLEIMAN et al., 1994). Translocation of Dok-3/Grb2 to the areas of BCR microcluster thus brings Dok-3 into close proximity of Lyn which increases the efficiency of Dok-3 phosphorylation.

Different lines of evidence confirm that the microsignalosomal translocation of Dok-3/Grb2 appears to be mediated by binding of the Grb2-cSH3 domain to the microsignalosomal residents SLP-65 and Vav3. First, the BCR-induced phosphorylation of 
Dok-3 is compromised in cells lacking SLP-65 or Vav3. Second, the association of Grb2 with Lyn is almost terminated in Vav3- and SLP-65 deficient cells.

Besides its function as a guanine nucleotide exchange factor, Vav3 also has adaptor functions by virtue of its $\mathrm{SH} 2$ domain and the two SH3 domains. Previous reports describe an interaction of Vav3 with phosphorylated SLP-65 upon BCR stimulation (WIENANDS et al., 1998). Furthermore, Grb2, by virtue of its C-terminal SH3 domain, has been reported to bind to PRRs located in the N-terminal SH3 domain of Vav1 (NISHIDA et al., 2001, RAMOS-MORALES et al., 1995; YE and BALTIMORE, 1994). Based on these data it was postulated that association of Grb2-cSH3 and Vav3-PRR might be utilized for translocating Vav3 into lipid rafts where association with SLP-65 then functions to sustain Vav residency in the rafts (JOHMURA et al., 2003). Batista and colleagues showed that Vav3 is translocated into microsignalosomes upon BCR engagement indicating that the areas with lipid raft properties at least partially overlap with the areas of BCR microcluster. My data imply that a ternary complex of Dok-3/Grb2/Vav3 translocates Dok-3/Grb2 into the microsignalosomes (figure 5.1). SLP-65 might either then stabilize the microsignalosomal abundance or even mediate the translocation itself.
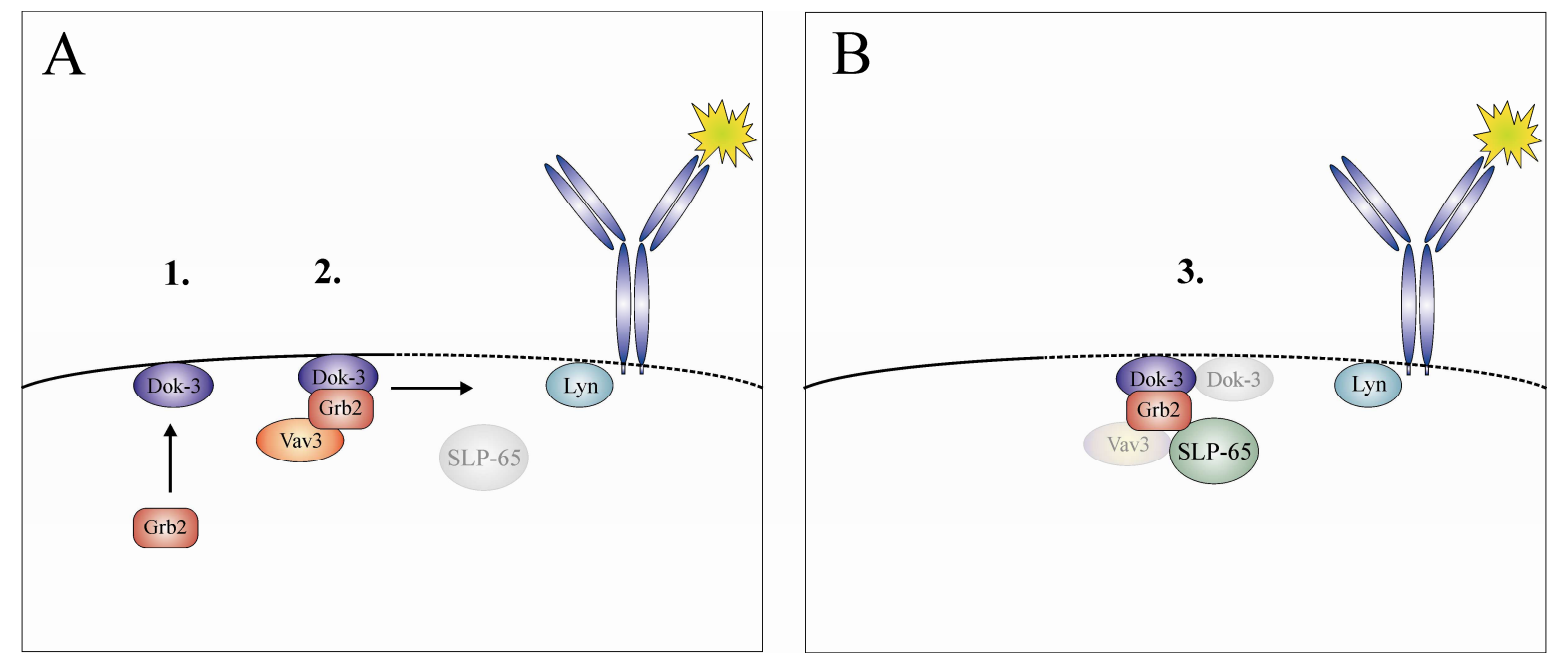

Figure 5.1: Dok-3/Grb2 is translocated to the microsignalosomes by binding to Vav3 and/or SLP-65

(A) Upon BCR engagement Grb2 (red) binds to phosphorylated Dok-3 (blue) by virtue of its $\mathrm{SH} 2$ domain and is thus recruited to the plasma membrane (1.). The Dok-3/Grb2 complex is translocated to the microsignalosomes (dashed line), a process depending on the C-terminal SH3 domain of Grb2 which is binding to Vav3 (green) (2.) (B) Once located in the microsignalosomes the Dok-3/Grb2 complex sustains in the microsignalosomes by binding either to other Dok-3 proteins or by association with SLP-65 (3.). 
Based on these data a redundant function of Vav3 and SLP-65 cannot be excluded. If SLP-65 is essential for the translocation of Dok-3/Grb2, a Grb2 binding-deficient SLP-65 should prevent translocation of, and thus $\mathrm{Ca}^{2+}$-inhibition by Dok-3/Grb2. In human B cells SLP-65 is expressed in two isoforms (FU and CHAN, 1997). The short isoform (s-SLP-65) lacks interaction with Grb2 due to a missing proline motif which is target of the $\mathrm{cSH} 3$ domain of Grb2 (GRABBE and WIENANDS, 2006). BCR-induced $\mathrm{Ca}^{2+}$ mobilization meanwhile is not altered in cells expressing s-SLP-65. Moreover, no difference in SLP-65/Vav3 or s-SLP-65/Vav3 interaction was observed, indicating that the SLP-65/Vav3 association is independent of Grb2. In cells lacking either Vav3 or SLP-65, the other protein could mediate the translocation and the reduced Dok-3 phosphorylation is just due to delayed translocation. While the data shown in this thesis provide clear evidence for the importance of SLP-65/Vav3 in Dok-3/Grb2 mediated $\mathrm{Ca}^{2+}$ inhibition, further studies are required to extract the exact function of SLP-65 and Vav3 in this process.

Once residing in the microsignalosomes phosphorylation of Dok-3 is more pronounced. This fact raises the question how an interaction that is based on tyrosine phosphorylation can increase the phosphorylation efficiency. It has been shown that phosphorylation of the tyrosine residue at position 140 of Dok-3 allows formation of homo-oligomers by virtue of phospho-tyrosine/PTB domain interactions (STORK et al., 2007). Hence, abundance of the Dok-3/Grb2 complex in the microsignalosomes could be further supported by the oligomerization of Dok-3 proteins. Although previous findings showed that phosphorylation of the $\mathrm{Y}^{140}$ is dispensable for BCR inhibition (STORK et al., 2007), the formation of oligomers might increase the abundance of Dok-3/Grb2 complexes in the microsignalosomes and thus support its function under conditions with low antigen concentration. First evidence has been given by the analysis of the Dok-3/Grb2 chimeric protein. This shows that substitution of the tyrosine residue 140 (Dok-3YYFF-cSH3) minors the inhibitory ability of the protein. In summary, data provided in this work show that although not being essential for Dok-3 function, the oligomerization of Dok-3 proteins seems to support the inhibition of BCR signals. 


\subsection{Dok-3-associated Grb2 contributes to negative regulation of BCR signals in BCR microsignalosomes.}

The binding of Dok-3 to Grb2 is mandatory for its translocation to the microsignalosomes. However, this is not the only function of Dok-3-associated Grb2.

This is most obvious from the analysis of cells expressing the TSH2-Dok-3 chimera. As the tandem-SH2 domain of Syk is binding to the phosphorylated ITAMs of Ig- $\alpha /-\beta$, this chimeric protein is directly translocated into the microsignalosomes in a Grb2-independent manner. Consistently, the TSH2-Dok-3 becomes strongly phosphorylated upon BCR engagement due to its close proximity to the BCR and Lyn. This process is independent of Grb2 binding as the $\mathrm{Y}^{331} \mathrm{~F}$ chimera is phosphorylated in a similar amount. Nonetheless, the association with Grb2 is still important to regulate the BCR-induced $\mathrm{Ca}^{2+}$ mobilization as the Grb2-binding deficient chimera is compromised in its ability to inhibit the $\mathrm{Ca}^{2+}$ flux. These data clearly confirm that Grb2-cSH3 function is not restricted to translocation of Dok-3 and allows for speculations about additional roles for Grb2-medaited negative regulation when associated with Dok-3.

These data also explain the previously weakly understood phenomenon that Dok-3 $\mathrm{Y}^{331} \mathrm{~F}$ has a dominant negative effect over endogenous Dok-3. According to the data shown in this thesis, Dok-3 $\mathrm{Y}^{331} \mathrm{~F}$ could "poison" Dok-3 oligomers in BCR microsignalosomes thereby reducing the amount of Grb2 in this localization. As I could show that Dok-3associated Grb2 is required in areas of BCR microcluster the altered Dok-3 oligomers are functionally compromised.

\subsection{Dok-3/Grb2 accentuates the negative regulatory functions of Lyn}

Beyond the details of Dok-3/Grb2 complex formation I elucidated the functional impact of this complex on BCR-mediated signal translocation. It was hypothesized earlier that Dok-3/Grb2 regulates Btk activity due to the finding that PLC- $\gamma 2$ phosphorylation and activity is compromised in presence of Dok-3/Grb2 (STORK et al., 2007). However, I here provide several lines of evidence that Dok-3/Grb2 inhibits $\mathrm{Ca}^{2+}$ mobilization by regulating processes upstream of the $\mathrm{Ca}^{2+}$ initiation complex formation. First, $\mathrm{Ca}^{2+}$ mobilization still can be regulated by Dok-3/Grb2 when Btk is not associated to the $\mathrm{Ca}^{2+}$ initiation complex. This could be shown by expressing a Btk-binding less SLP-65 variant in slp-65 cells. In these cells Dok-3 $\mathrm{Y}^{331} \mathrm{~F}$ still has a dominant negative function. Second, Sykmediated phosphorylation of PLC- $\gamma 2$ binding sites in SLP-65 is attenuated by Dok-3/Grb2, implicating that Syk is regulated by Dok-3/Grb2. Third, it was shown that Syk becomes 
less phosphorylated in cells expressing Dok-3 and that this altered phosphorylation reduces its kinase activity leading to the decreased phosphorylation of the PLC- $\gamma 2$ binding sites of SLP-65. This then destabilizes the $\mathrm{Ca}^{2+}$ initiation complex resulting in reduced PLC- $\gamma 2$ phosphorylation and compromised $\mathrm{IP}_{3}$ production as described earlier. Furthermore this impact on Syk tyrosine phosphorylation is restricted to a specific phosphorylation site inside the protein. Out of five detected phospho-tyrosine sites only one has an altered phosphorylation level in presence of Dok-3 compared to dok- $3^{-/}$control cells. This tyrosine $\left(\mathrm{Y}^{352}\right)$, together with $\mathrm{Y}^{348}$, has been shown to mediate allosteric regulation of Syk (TSANG et al., 2008). They are located in the Interdomain B (linker region between cSH2 and the kinase domain) of Syk and their corresponding residues in the T-cell analogue ZAP-70 ( $\mathrm{Y}^{315}$ and $\left.\mathrm{Y}^{319}\right)$ have been described to mediate an intramolecular interaction with the $\mathrm{nSH} 3$ domain which keeps the protein in an inactive conformation (BRDICKA et al., 2005, DEINDL et al., 2007). Phosphorylation of $\mathrm{Y}^{348}$ was not identified in mass spectrometry analysis but due to their functional complementarities I would assume a similar effect of Dok-3 on this tyrosine. Phosphorylation of Syk is mediated by two distinct processes. Besides its Lyn-dependent phosphorylation several motifs of Syk have been described as auto-phosphorylation sites (FURLONG et al., 1997). However, the exact role of these two processes remains widely obscure to date. Despite reports that say $\mathrm{Y}^{352}$ is an auto-phosphorylation site I herein could show that the auto-phosphorylation process of Syk is not altered by Dok-3 indicating a participation of Lyn in phosphorylation of this motif.

Based on the results shown in this thesis it cannot be excluded that instead of the Lyndependent Syk phosphorylation, Dok-3/Grb2 regulates Syk dephosphorylation. However, I could show that SHP-1, which has been shown to dephosphorylate Syk (TUSACNO et al., 1996; LAW et al., 1996), is not affected by Dok-3/Grb2. Moreover there is no evidence in the literature that dephosphorylation processes can be strictly site specific. Collectively, the data presented here provide strong evidence that Dok-3/Grb2 negatively regulates the Lynmediated phosphorylation of Syk leading to a reduced efficiency of $\mathrm{Ca}^{2+}$ mobilizing enzymes. This is supported by the fact that Dok-3/Grb2 has no inhibitory functions in cells lacking Lyn expression.

Up to this it could be shown that Dok-3/Grb2 regulates Lyn-dependent processes. Although data presented in this thesis reveal that phosphorylation and kinase activity of Lyn are not affected by Dok-3/Grb2, the complex cannot function in absence of Lyn. A Dok-3/Grb2 chimeric protein that is independent of Lyn-mediated Dok-3 phosphorylation cannot inhibit $\mathrm{Ca}^{2+}$ mobilization in Lyn-deficient DT40 cells. Thus the regulatory influence 
of Dok-3/Grb2 on Lyn-mediated processes rather affects Lyn itself as the effectors which become phosphorylated by Lyn.

Lyn plays a major role in positive as well as negative regulation of BCR signals. In the absence of Lyn, BCR signaling is supported by Blk and Fyn, but inhibitory receptors are ineffective at down-regulation of BCR signaling, thereby leading to hyper-responsiveness (XU et al., 2005). Lyn deficient mice do not only reveal a reduced number of mature B cell, but also establish a hyper-responsive phenotype and produce auto-reactive antibodies. B cells from these mice have a prolonged proliferation response and enhanced MAPK activation upon BCR engagement (HIBBS et al., 1995; NISHIZUMI et al., 1995; CHAN et al., 1997; DeFRANCO et al., 1998). Beyond the effectors involved in positive regulation, Lyn phosphorylates several proteins involved in negative regulation including ITIM-bearing receptors like CD22 (SMITH et al., 1998; CORNALL et al., 1998) and FcyRIIB CHAN et al., 1997; NISHIZUMI et al., 1998), as well as the inositol-phosphatase SHIP or the phosphatases SHP-1 and -2 (CORNALL et al., 1998; CHAN 1998). Its dual function in signal regulation thus makes it a feasible target for regulation. Furthermore, Lyn is the only Src kinase expressed in DT40 cells (TAKATA et al., 1994).

The data provided in this thesis show that beyond the attenuating effect of Dok-3/Grb2 on Syk phosphorylation and activity, Lyn targets involved in negative regulation of BCRinduced $\mathrm{Ca}^{2+}$ signaling are more efficiently phosphorylated. First, Dok-3/Grb2 increases the phosphorylation of the inositol-phosphatase SHIP, which promotes the activity of the phosphatase. SHIP then hydrolyzes $\mathrm{PIP}_{3}$ to $\mathrm{PIP}_{2}$ thereby reducing the binding sites for the $\mathrm{PH}$ domains of e.g. Btk and PLC- $\gamma 2$ and thus destabilizing the $\mathrm{Ca}^{2+}$ initiation complex (DAMEN et al., 1996). Dok-3 is associated to SHIP upon BCR stimulation by virtue of an interaction of its PTB domain with $\mathrm{pY}^{1020}$ of SHIP (STORK et al., 2007). This association is stabilized by the binding of the C-terminal SH3 domain of Grb2 to a proline-rich motif of SHIP (HARMER and DeFRANCO, 1999; NEUMANN, 2011). However, association of Dok-3 and SHIP is dispensable for the $\mathrm{Ca}^{2+}$ inhibitory effect of the Dok-3/Grb2 complex as it has been shown that expression of a SHIP binding-deficient Dok-3 did not alter the $\mathrm{Ca}^{2+}$ inhibitory effect of Dok-3/Grb2. Moreover, the $\mathrm{Ca}^{2+}$ regulatory effect of Dok-3/Grb2 has been observed in ship ${ }^{-/-}$DT40 cells (STORK et al., 2007; NEUMANN, 2008). Conversely, showing that SHIP is not required for Dok-3/Grb2 function does not mutually exclude the possibility that Dok-3 utilizes SHIP for signal inhibition, as I could show that Dok-3/Grb2 regulates the phosphorylation of SHIP. This goes in line with data obtained in B cells of both knock-out mice. Like the hyperproliferative B cells from Dok-3-deficient 
mice, those of SHIP-deficient mice are hypersensitive to BCR mediated signals and less sensitive to induction of apoptosis (HELGASON et al., 1998, LIU et al., 1998; HELGASON et al., 2000; BRAUWEILER et al., 2000; NG et al., 2007).

One key question remaining is the ambiguity role of Grb2 for SHIP function and phosphorylation. Whereas absence of Dok-3 only slightly reduces phosphorylation of SHIP, Grb2-deficiency markedly diminishes phosphorylation of the protein (HARMER and DeFRANCO, 1999, NEUMANN, 2008). This shows that Grb2 is responsible for the phosphorylation and activation of SHIP in a Dok-3-independent manner, whereas binding to Dok-3 switches its function to modification of the SHIP phosphorylation. This switch can be ascribed on the role of Grb2-cSH3. Its interaction with SHIP cannot be responsible for initial $\mathrm{Ca}^{2+}$ inhibition as it is involved in translocation of Dok-3/Grb2 into the microsignalosomes. But once residing in the microsignalosomes either a change to an association of $\mathrm{cSH} 3$ with SHIP or the oligomerization-induced accumulation of Dok-3/Grb2 complexes could link Dok-3/Grb2 with the phosphatase and thus modify its activity. This also further contributes Grb2 a role in negative regulation inside of the microsignalosomes.

As Dok-3/Grb2 also functions in absence of SHIP the complex affects more than this inhibitory Lyn target. Another Lyn target that is more efficiently phosphorylated in presence of Dok-3/Grb2 is the phosphatase SHP-2. Analysis of the BCR-induced phosphorylation of SHP-2 shows that the expression of Dok-3/Grb2 increases the stimulation dependent tyrosine phosphorylation of the protein. Although the human SHP-2 gene is related to disorders like the Noonan-Syndrome (TARTAGLIA et al., 2001) as well as to leukemia (TARTAGLIA et al., 2003, LOH et al., 2004) little is known about its function downstream of the BCR receptor. Studying SHP-2 function is hampered by the embryonic lethality which goes along with the gene-targeting of the SHP-2 alleles (SAXTON et al., 1997; SAXTON and PAWSON, 1999; SAXTON et al., 2000). But in vitro studies in fibroblasts show that SHP-2 has positive regulatory functions as it promotes Erk activation upon cytokine and growth factor stimulation (NOGUCHI et al., 1994, YAMAUCHI et al., 1995; TANG et al., 1995). Studies revealing its function in TCR signaling imply a different regulatory role for SHP-2 in antigen-induced signaling. Transgenic mice expressing a putative dominant negative mutant (SHP-2 C/S) have a decreased phosphorylation of LAT and lower magnitudes of $\mathrm{Ca}^{2+}$ flux upon TCR stimulation whereas the overall TCR response was unchanged (SALMOND et al., 2005). Considering these results, Salmond and colleagues suggest a regulatory role for SHP-2 in 
Th2-type responses. Although the role of SHP-2 in BCR-mediated $\mathrm{Ca}^{2+}$ signaling remains completely unclear to date, these data imply that despite its activatory function downstream of cytokine- and growth-factor receptors, SHP-2 has a negative regulatory function downstream of antigen-receptors. Moreover, it is not understood whether and how SHP-2 is translocated into BCR microsignalosomes. The related phosphatase SHP-1 contains a six amino acid sequence in its C-terminus which mediates constitutive lipid raft localization (FAWCETT and LORENZ, 2005). The sequence of SHP-2 does not contain such a sequence. Nonetheless a fraction of SHP-2 could be localized in lipid rafts of T cells upon stimulation (BARBAT et al., 2007). SHP-2 is one of the binding partners described for the $\mathrm{cSH} 3$ domain of Grb2. Translocation of the phosphatase into BCR microsignalosomes thus could be mediated by a direct association of SHP-2 with the Dok-3/Grb2 complex. Indeed BCR-induced SHP-2 tyrosine phosphorylation requires Dok-3/Grb2. This is obvious from the fact that in $d o k-3^{-/}$cells SHP-2 tyrosine phosphorylation is not affected by BCR engagement. However, this study shows that integration of SHP-2 in the BCR signaling cascade requires Dok-3/Grb2 and gives evidence that SHP-2 encompasses negative regulatory functions in BCR-mediated signaling processes.

Collectively, I could show that Dok-3/Grb2 modulates the balance of inhibitory and activatory Lyn-functions. While Dok-3/Grb2 attenuates activation of Syk, integration of SHP-2 and SHIP is augmented in this situation. Once, Dok-3/Grb2 is translocated into BCR microsignalosomes it might shape the spatial organization of signal regulators ultimately leading to reduced efficiency of $\mathrm{Ca}^{2+}$ mobilizing enzymes (figure 5.2). Hence, I elucidated the molecular details of regulatory processes that contribute to differential BCR signaling. The function of Dok-3/Grb2 is an example how adaptor proteins manipulate spatial organization of signalosomes leading to altered functions of effector proteins without changing their general activity. 

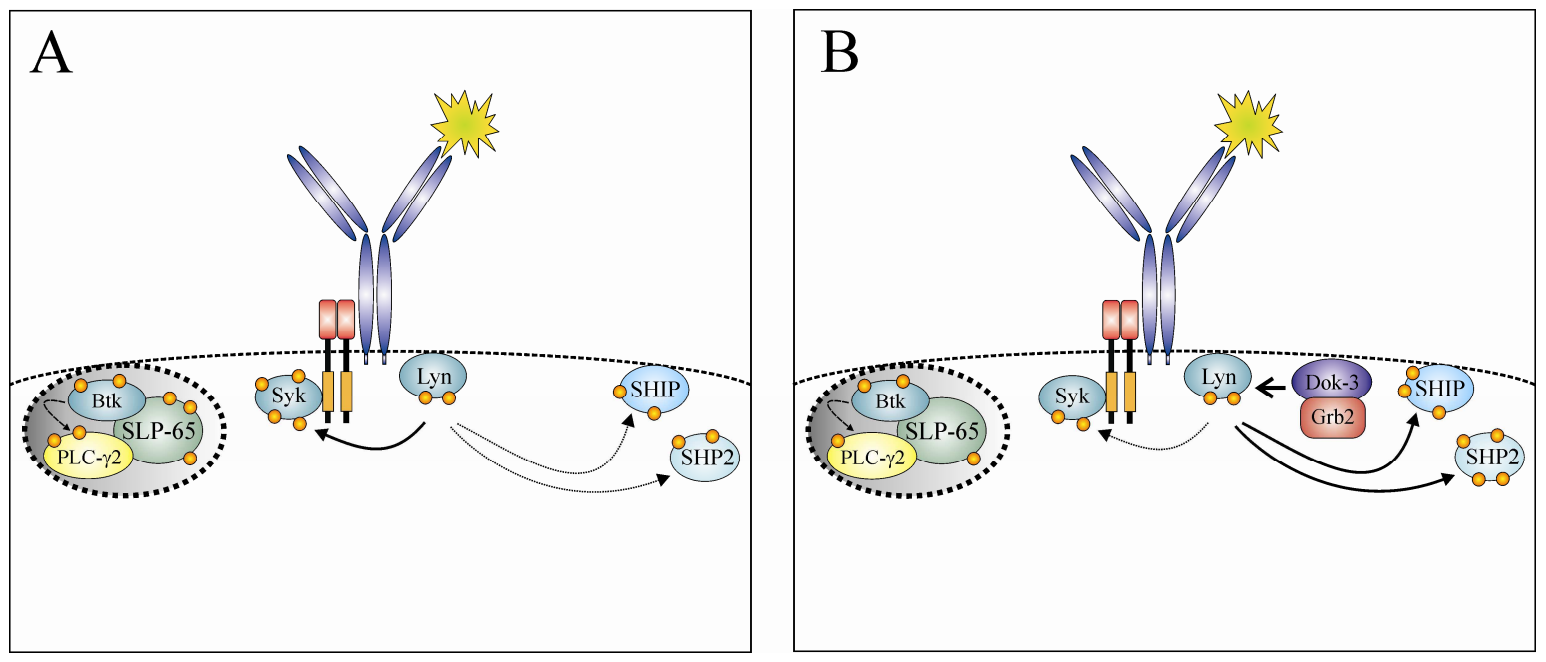

Figure 5.2: The Dok-3/Grb2 alters the phosphorylation pattern of several Lyn substrates

Engagement of the BCR leads to the phosphorylation (orange dots) of several effectors by the Src kinase Lyn (arrows). (A) Cells that do not express Dok-3 have a high phosphorylation level of positive regulators like Syk (thick arrow) whereas negative regulators like SHIP and SHP-2 become less extensively phosphorylated (small arrows). (B) In cells expressing Dok-3 the formation of the Dok-3/Grb2 complex changes the phosphorylation level of several effectors. Besides a decreased phosphorylation of Syk the negative regulators SHIP and SHP-2 become stronger phosphorylated.

This work gains detailed insight into a process crucial for the regulation of the BCRinduced $\mathrm{Ca}^{2+}$ mobilization. The translocation of Dok-3/Grb2 gives further evidence about the importance of localization of effectors with regard to their function. The shifting of the Dok-3/Grb2 complex into the microsignalosomes is essential for its participation in the negative regulation of the $\mathrm{Ca}^{2+}$ mobilization. The stimulation depending interplay of Dok-3 and Grb2 further highlights, that adaptor proteins can mediate regulatory processes by shaping the co-operation of other effectors and thus changing the effector functions of single proteins as shown for phosphorylation pattern of several Lyn-substrates (figure 5.2). The data presented here underline the importance of the analysis of areas of microcluster in the membrane. Using different in-vivo-life-imaging techniques could further improve the dynamic movement and involvement of BCR-signaling effectors inside of the microsignalosomes and could give more help to understand the role of these microdomains in PTK mediated signaling processes. 


\section{Summary}

Basis of the humoral immune response is the generation and activation of antigen-specific B lymphocytes. Signal transduction by the B cell antigen receptor (BCR) regulates both, the activation of pathogen-specific B cells as well as removal of self-reactive B cells and signals emanating from the BCR can either induce apoptosis or proliferation. The rise of the cytosolic $\mathrm{Ca}^{2+}$ concentration is a central step in the activation of $\mathrm{B}$ lymphocytes. The profile of the $\mathrm{Ca}^{2+}$ signal contributes to the activation of different transcription factors which then affect cell fate decisions. Hence, regulation of $\mathrm{BCR}$-induced $\mathrm{Ca}^{2+}$ mobilization is important to keep the balance between humoral immunity and tolerance. In 2007, the adaptor protein Downstream of kinase-3 (Dok-3) was identified as one important regulator of differential $\mathrm{Ca}^{2+}$ mobilization. Lyn-dependent complex formation of Dok-3 with the growth factor receptor bound protein 2 (Grb2) attenuates the efficiency of $\mathrm{Ca}^{2+}$ mobilizing enzymes. In this study I investigated the molecular mechanism leading to the formation of the Dok-3/Grb2 module and its influence on the rise of the intracellular $\mathrm{Ca}^{2+}$ level.

Using gene targeting and reconstitution experiments in the chicken B cell line DT40 I could show that the association of plasma membrane-bound Dok-3 with Grb2 translocates the proteins into microsignalosomes, membrane regions at which activated BCR and their downstream effectors accumulate and thus signaling occurs. Once residing in the microsignalosomes I could show that Dok-3/Grb2 directly affects the phosphorylation pattern of Lyn targets. The $\mathrm{Ca}^{2+}$ mobilizing enzyme Syk become less phosphorylated and activated in cells expressing Dok-3/Grb2 leading to a lower magnitude of $\mathrm{Ca}^{2+}$ flux upon BCR-engagement. Beyond this inhibitory impact on the generation of the $\mathrm{Ca}^{2+}$ signal, further Lyn targets, known to be involved in $\mathrm{Ca}^{2+}$ regulatory processes, become specifically stronger phosphorylated. The tyrosine-phosphorylation levels of the phosphatases SHIP and SHP-2 increase upon BCR engagement whereas the phosphorylation of other regulators, e.g. SHP-1, is not affected. Although phosphorylation and kinase activity of Lyn itself are not altered by Dok-3/Grb2 the data clearly confirm that presence of Lyn is mandatory for the Dok-3/Grb2 function.

These data reveal insight into the molecular mechanisms of the Dok-3/Grb2 mediated regulatory process shaping the BCR-induced $\mathrm{Ca}^{2+}$ mobilization. Dok-3 modulates the balance of activatory and inhibitory Lyn functions by changing the composition of BCR microsignalosomes. This adaptor-mediated regulation may influence B cell fate by either supporting activation or tolerance induction. 


\subsection{Zusammenfassung}

Grundlage der humoralen Immunantwort ist die Entwicklung und Aktivierung von antigenspezifischen B-Lymphocyten. Signale des B-Zell-Antigenrezeptors (BCR) regulieren sowohl die Aktivierung pathogenspezifischer B-Zellen als auch die Beseitigung selbstreaktiver B-Zellen. BCR vermittelte Signale können sowohl Apoptose als auch Proliferation induzieren. Der Anstieg der intrazellulären $\mathrm{Ca}^{2+}-$ Konzentration ist ein zentraler Schritt während der Aktivierung von B-Zellen. Das Profil des $\mathrm{Ca}^{2+}{ }_{-}$Signals vermittelt die Aktivierung verschiedener Transkriptionsfaktoren, welche dann das Schicksal der Zelle beeinflussen. Folglich ist die Regulation der BCR-induzierten $\mathrm{Ca}^{2+}$-Mobilisierung wichtig für das Gleichgewicht zwischen humoraler Immunität und Toleranz. 2007 wurde das Adapterprotein Downstream of kinase-3 (Dok-3) als wichtiger Regulator der $\mathrm{Ca}^{2+}$-Mobilisierung identifiziert. Die Lyn-vermittelte Assoziation von Dok-3 mit dem growth factor receptor-bound protein 2 (Grb2) mindert die Effizienz von $\mathrm{Ca}^{2+}$-mobilisierenden Enzymen. In dieser Arbeit wurden die molekularen Mechanismen der Dok-3/Grb2-Komplexbildung und dessen Einfluss auf den Anstieg des intrazellulären $\mathrm{Ca}^{2+}$-Levels untersucht.

Mittels zielgerichteter Gen-Inaktivierung and anschließender Rekonstitution in der Hühner B-Zelllinie DT40 konnte ich zeigen, dass die Verbindung von Plasmamembranassoziiertem Dok-3 mit Grb2 diesen Komplex in Mikrosignalosomen verlagert. Mikrosignalosomen sind Regionen in der Membran, in denen aktivierte BCRs und ihre proximalen Effektoren akkumulieren und dementsprechend Signalgebung erfolgt. Ich konnte zeigen, dass der Dok-3/Grb2-Komplex nach Verlagerung in die Mikrosignalosomen den Phosphorylierungsstatus verschiedener Lyn Substrate beeinflusst. In Zellen die Dok-3/Grb2 exprimieren wird das $\mathrm{Ca}^{2+}$-mobilisierende Enzym Syk schwächer phosphoryliert und aktiviert. Dies reduziert die Stärke des $\mathrm{Ca}^{2+}$-Flusses nach BCR-Aktivierung. Neben dem hemmenden Einfluss auf die Entstehung des $\mathrm{Ca}^{2+}$ Signals, werden zusätzlich Lyn Substrate, welche an der Regulation dieses Signals beteiligt sind, stärker phosphoryliert. Die Tyrosin-phosphorylierung der Phosphatasen SHIP und SHP-2 steigen nach BCR-Aktivierung, wohingegen die Phosphorylierung anderer Regulatoren, z. Bsp. SHP-1, nicht beeinflusst wird. Obwohl die Phosphorylierung und Aktivität von Lyn nicht von Dok-3/Grb2 beeinflusst werden, zeigen die Daten, dass die Anwesenheit von Lyn obligatorisch für die Dok-3/Grb2 Funktion ist. 
Alles in allem geben die Daten Einblicke in die molekularen Mechanismen der Dok-3/Grb2-vermittelten regulatorischen Prozesse, welche die BCR-vermittelte $\mathrm{Ca}^{2+}$-Mobilisierung formen. Dok-3 beeinflusst die Ausgewogenheit zwischen aktivierenden und inhibierenden Lyn-Funktionen indem es die Zusammensetzung von BCR-Mikrosignalosomen ändert. Diese Adapter-vermittelte Regulation kann demnach das Schicksal von B-Zellen beeinflussen indem es alternativ Prozesse zur Aktivierung der Zelle oder zur Toleranzbildung unterstütz. 


\section{$7 \quad$ Material and Methods}

\subsection{Materials}

All chemicals and biologically reactive reagents were purchased from Roth, SigmaAldrich, Serva, Applichem, Merck, Invitrogen, Invivogen, PAA, Becton Dickinson, or Amersham Biosciences. All chemicals were purchased in pA quality unless otherwise indicated.

\subsubsection{Antibodies}

Table 7.1: Primary antibodies

(IP: Immunopurification, IB: Immunoblot)

\begin{tabular}{|l|l|l|l|l|}
\hline antibody & Immunogen & Source & Supplier/reference & application \\
\hline HA* (3F10) & HA-Epitop & rat & Roche & $\begin{array}{l}\text { IP: } 0.2 \mu \mathrm{g} \\
\text { IB: } 1: 1000\end{array}$ \\
\hline GFP (cl. 7.1/13.1) & GFP & mouse & Roche & $\begin{array}{l}\text { IP: } 0.4 \mu \mathrm{g} \\
\text { IB: } 1: 1000\end{array}$ \\
\hline chicken IgM (M4) & $\begin{array}{l}\text { chicken IgM } \\
\text { heavy chain }\end{array}$ & mouse & Biozol & $\begin{array}{l}\text { DT40 } \\
\text { stimulation }\end{array}$ \\
\hline $\begin{array}{l}\text { Phosphotyrosine } \\
\text { pTyr) }(4 G 10)\end{array}$ & Phosphotyramin & mouse & Upstate Biotech & IB: $1 \mu \mathrm{g} / \mathrm{mL}$ \\
\hline $\begin{array}{l}\text { Dok-3 } \\
\text { hicken Dok-3 }\end{array}$ & rabbit & this thesis & $\begin{array}{l}\text { IP: } 1 \mu 1 \\
\text { IB: } 1: 10.000\end{array}$ \\
\hline $\begin{array}{l}\text { Actin } \\
\text { Alexa Fluor }{ }^{319} / \text { Syk } Y^{352}\end{array}$ & human actin & rabbit & Sigma & IB: $1: 2000$ \\
\hline pSLP-65 (Y & human SLP-65 & rabbit & Chiu et al., 2002 & IB: $2.5 \mu \mathrm{g} / \mathrm{mL}$ \\
\hline pSLP-65 (Y
\end{tabular}




\begin{tabular}{|l|l|l|l|l|}
\hline pSHIP $\left(\mathrm{Y}^{1020}\right)$ & mouse SHIP & rabbit & $\begin{array}{l}\text { Cell Signaling } \\
\text { Technology }\end{array}$ & IB: $1: 1000$ \\
\hline pLyn $\left(\mathrm{Y}^{507}\right)$ & human Lyn & rabbit & $\begin{array}{l}\text { Cell Signaling } \\
\text { Technology }\end{array}$ & IB: $1: 1000$ \\
\hline pSrc $\left(\mathrm{Y}^{416}\right)$ & human Src & rabbit & $\begin{array}{l}\text { Cell Signaling } \\
\text { Technology }\end{array}$ & IB: $1: 1000$ \\
\hline SHP-1 $(\mathrm{C}-19)$ & $\begin{array}{l}\text { human SH-PTP1 } \\
\text { (SHP1) }\end{array}$ & rabbit & Santa Cruz & IB: $0.4 \mu \mathrm{g} / \mathrm{mL}$ \\
\hline SHP-2 (N-16) & human SH-PTP2 & rabbit & Santa Cruz & $\begin{array}{l}\text { IP: } 1 \mu \mathrm{g} / \mathrm{mL} \\
\text { IB: } 1: 500\end{array}$ \\
\hline c-Cbl & human c-Cbl & mouse & $\begin{array}{l}\text { Cell Signaling } \\
\text { Technology }\end{array}$ & $\begin{array}{l}\text { IP: } 0.75 \mu \mathrm{g} / \mathrm{ml} \\
\text { IB: } 1: 2500\end{array}$ \\
\hline GST & GST & rabbit & Molecular Probes & IB: $1: 3000$ \\
\hline
\end{tabular}

*HA = eleven amino acid peptide derived from the human influenza hemagglutinin protein (YPYDVPDYA)

\section{Secondary antibodies}

For Western-blot analysis HRPO-conjugated secondary antibodies were used in a dilution of 1:10.000. For ELISA antibodies were used in a 1:500 dilution.

Table 7.2: Secondary antibodies

\begin{tabular}{|l|l|}
\hline antibody & Supplier/reference \\
\hline \hline goat-anti-rabbit IgG & Pierce \\
\hline goat-anti-rat & Pierce \\
\hline goat-anti-mouse & Pierce \\
\hline goat-anti-mouse IgG1 & Southern Biotech \\
\hline goat-anti-mouse IgG2b & Southern Biotech \\
\hline
\end{tabular}




\subsubsection{Enzymes}

Restriction Endonucleases

Calf Intestine Phosphatase (CIP)

T4 DNA Ligase

$P f u$ DNA Polymerase

Taq DNA Polymerase

Taq PCR Master Mix Kit

LA-Taq DNA Polymerase Takara
New England Biolabs

New England Biolabs

New England Biolabs

Promega

New England Biolabs

Qiagen

TaKaRa (Cambrex)

\subsubsection{Vectors}

Table 7.3: Vectors

\begin{tabular}{|c|c|c|}
\hline Vector & Source/supplier & application \\
\hline \multicolumn{3}{|l|}{ cloning vectors } \\
\hline pCRII-Topo & Invitrogen & T/A cloning \\
\hline pBluescript SK II (-) & Stratagene & targeting constructs \\
\hline pEGFP-N1 & BD Bioscience & Cloning of GFP-tagged proteins \\
\hline p-bleo & T. Kurosaki & $\begin{array}{l}\text { bleomycin resistance cassette for } \\
\text { targeting constructs (with } \beta \text {-actin } \\
\text { promotor) }\end{array}$ \\
\hline p-gpt & T. Kurosaki & $\begin{array}{l}\text { gpt resistance cassette for targeting } \\
\text { constructs (with } \beta \text {-actin promotor) }\end{array}$ \\
\hline \multicolumn{3}{|c|}{ bacterial expression vectors } \\
\hline pGex-4T-1 & $\begin{array}{l}\text { Amersham } \\
\text { Bioscience }\end{array}$ & $\begin{array}{l}\text { expression of GST/mGrb2[SH2] and } \\
\text { GST/mGrb2[cSH3] }\end{array}$ \\
\hline \multicolumn{3}{|c|}{ mammalian expression vectors } \\
\hline pABESpuroII & & $\begin{array}{l}\text { expression in DT40; constructs used } \\
\text { for electroporation (see 7.5.2.3) }\end{array}$ \\
\hline pMSCVpuro & $\begin{array}{l}\text { BD Biosciences } \\
\text { Clontech }\end{array}$ & \multirow{3}{*}{$\begin{array}{l}\text { expression in DT40; constructs used } \\
\text { for retroviral gene transfer (see 7.5.2.4 } \\
\text { and 7.5.2.5) }\end{array}$} \\
\hline pMSCVblast & B. Stork & \\
\hline pMSCVbleo & M. Engelke & \\
\hline pHCMV-VSV-G & M. Jücker & $\begin{array}{l}\text { expression of VSV-G/pseudo-typing } \\
\text { of retroviruses }\end{array}$ \\
\hline
\end{tabular}




\subsubsection{Oligonucleotides}

All nucleotides were synthesized by MWG Biotech (Ebersberg, Germany) or Operon (Germany)

Table 7.4: Oligonucleotides

\begin{tabular}{|c|c|c|}
\hline Primer & Sequence $\left(5^{\prime} \rightarrow 3^{\prime}\right)$ & application \\
\hline chDok-3genrev2 & tgc cat gat gtc acc cat aat gtg c & genomic PCR (screen) \\
\hline bleoA & tac gag gag cgc ttt tgt tt & genomic PCR (screen) \\
\hline gpt1 1724 for & $\operatorname{cgc} \operatorname{tgg} \operatorname{ttg}$ atg act atg ttg $\mathrm{t}$ & genomic PCR (screen) \\
\hline chSyk LA for1 & tgc gaa cet tgc ctc atc tca gtg gat aca & genomic PCR (left arm) \\
\hline chSyk LA rev1 & gcc tgg aca gct aag tac tgt cet atc g & genomic PCR (left arm) \\
\hline chSyk RA for1 & $\begin{array}{l}\text { taat gga tcc ggc tac atg ctg act gec ttg } \\
\text { ctt } g\end{array}$ & $\begin{array}{l}\text { genomic PCR (right } \\
\text { arm) }\end{array}$ \\
\hline chSyk RA rev1 & $\begin{array}{l}\text { taat gcgg cegc ctg tgc tgg tgg taa tgt } \\
\text { act g }\end{array}$ & $\begin{array}{l}\text { genomic PCR (right } \\
\text { arm) }\end{array}$ \\
\hline Syk screenLAfor 2 & act cet tta aat gta ctg acg ctt g & genomic PCR (screen) \\
\hline chSyk Ex1rev & cac gtg taa tat tgc caa aga agt & genomic PCR (screen) \\
\hline hSHP1 Eco for & taat gaa ttc tct ccg gaa gec ccc agg atg & cloning \\
\hline hSHP1 Eco rev & $\begin{array}{l}\text { taat gaa ttc cac cgc tca ctt cet ctt gag } \\
\text { gga }\end{array}$ & cloning \\
\hline for Eco Dok-3 & $\begin{array}{l}\text { taat gaa ttc atg gag aga cca gtg aag } \\
\text { gat }\end{array}$ & cloning \\
\hline rev Xho Grb2 & taat ctc gag gcc ctt cta gat gtt $\mathrm{ccg}$ & cloning \\
\hline hSyk Y342D for & cac aga ggt gga cga gag ccc c & mutagenesis \\
\hline hSyk Y342D rev & ggg gct ctc gtc cac ctc tgt g & mutagenesis \\
\hline hSyk Y346D for & acg aga gcc ccg acg agg acc & mutagenesis \\
\hline hSyk Y346D rev & ggg tcc gag tcg ggg ctc tcg $t$ & mutagenesis \\
\hline
\end{tabular}




\subsubsection{Constructs}

Table 7.5: Constructs

\begin{tabular}{|c|c|c|}
\hline Name & properties & application \\
\hline Dok-3 wt & $\begin{array}{l}\text { chicken Dok-3; N-terminal HA-tag or C- } \\
\text { terminal GFP-tag }\end{array}$ & Dr. Ingo Goldbeck \\
\hline Dok-3 $\mathrm{Y}^{331} \mathrm{~F}$ & $\begin{array}{l}\text { chicken Dok-3 } \mathrm{Y}^{331} \mathrm{~F} ; \mathrm{N} \text {-terminal HA- } \\
\text { tag or C-terminal GFP-tag }\end{array}$ & Dr. Ingo Goldbeck \\
\hline TSH2-Dok-3 & $\begin{array}{l}\text { aa 1-192 of human Syk fused to aa 114- } \\
426 \text { of chicken Dok-3; C-terminal GFP- } \\
\text { tag }\end{array}$ & Dr. Michael Engelke \\
\hline TSH2-Dok-3 $\mathrm{Y}^{331} \mathrm{~F}$ & $\begin{array}{l}\text { aa 1-192 of human Syk fused to aa 114- } \\
426 \text { of chicken Dok-3 } \mathrm{Y}^{331} \mathrm{~F} \text {; C-terminal } \\
\text { GFP-tag }\end{array}$ & Dr. Michael Engelke \\
\hline $\begin{array}{l}\text { Dok-3 } \Delta \text { YEN- } \\
\text { Grb2[cSH3] }\end{array}$ & $\begin{array}{l}\text { aa 1-322 of chicken Dok-3 fused to aa } \\
151-217 \text { of Grb2; C-terminal GFP-tag }\end{array}$ & Dr. Ingo Goldbeck \\
\hline $\begin{array}{l}\text { Dok-3 } \triangle \mathrm{YEN}- \\
\left.\text { Grb2[cSH3 } \mathrm{W}^{193} \mathrm{~K}\right]\end{array}$ & $\begin{array}{l}\text { aa 1-322 of chicken Dok-3 fused to aa } \\
151-217 \text { of Grb2 } \mathrm{W}^{193} \mathrm{~K} \text {; C-terminal } \\
\text { GFP-tag }\end{array}$ & Dr. Ingo Goldbeck \\
\hline $\begin{array}{l}\text { Dok-3 } 3 \text { YEN[YYFF]- } \\
\text { Grb2[cSH3] }\end{array}$ & $\begin{array}{l}\text { aa 1-322 of chicken Dok-3 } \mathrm{Y}^{140 / 307} \mathrm{~F} \\
\text { fused to aa } 151-217 \text { of Grb2; C-terminal } \\
\text { GFP-tag }\end{array}$ & this thesis \\
\hline $\begin{array}{l}\text { Dok-3 } \triangle \mathrm{YEN}[\mathrm{YYFF}]- \\
\left.\text { Grb2[cSH3 } \mathrm{W}^{193} \mathrm{~K}\right]\end{array}$ & $\begin{array}{l}\text { aa } 1-322 \text { of chicken Dok-3 } \mathrm{Y}^{140 / 307} \mathrm{~F} \\
\text { fused to aa } 151-217 \text { of Grb2 } \mathrm{W}^{193} \mathrm{~K} \text {; C- } \\
\text { terminal GFP-tag }\end{array}$ & this thesis \\
\hline SLP-65 wt & chicken SLP-65; N-terminal Citrin-tag & Dr. Ingo Goldbeck \\
\hline SLP-65 $\mathrm{Y}^{115} \mathrm{~F}$ & $\begin{array}{l}\text { chicken } \quad \text { SLP-65 } \\
\text { Citrin-tag }\end{array}$ & Dr. Ingo Goldbeck \\
\hline Syk wt & human Syk; C-terminal Strep-tag & Hanibal Bohnenberger \\
\hline Syk $\mathrm{Y}^{348 / 352} \mathrm{D}$ & $\begin{array}{l}\text { human Syk } \mathrm{Y}^{348 / 352} \mathrm{D} ; \text { C-terminal Citrin- } \\
\text { tag }\end{array}$ & thisd thesis \\
\hline Lyn wt & mouse Lyn; C-terminal HA-tag & $\begin{array}{l}\text { Dr. Konstantin } \\
\text { Neumann }\end{array}$ \\
\hline SHP-1 & human SHP-1; C-terminal GFP-tag & Dr. Michael Engelke \\
\hline pchDok-3-bleo & $\begin{array}{l}\text { gene targeting of chicken Dok-3, } \\
\text { introduces bleomycin resistance cassette } \\
\text { into intron } 1\end{array}$ & $\begin{array}{l}\text { Dr. Björn Stork, this } \\
\text { thesis }\end{array}$ \\
\hline pchDok-3-gpt & $\begin{array}{l}\text { gene targeting of chicken Dok-3, } \\
\text { introduces mycophenolic acid resistance } \\
\text { cassette into intron } 1\end{array}$ & $\begin{array}{l}\text { Dr. Björn Stork, this } \\
\text { thesis }\end{array}$ \\
\hline
\end{tabular}




\begin{tabular}{|l|l|l|}
\hline pchSyk-bleo & $\begin{array}{l}\text { gene targeting of chicken Syk, replaces } \\
\text { exons 1 and 2, bleomycin resistance } \\
\text { cassette }\end{array}$ & this thesis \\
\hline GST-Grb2 & mouse Grb2; N-terminal GST-tag & Dr. Annika Grabbe \\
\hline GST-Grb2 [cSH3] & $\begin{array}{l}\text { C-terminal SH3 domain of mouse Grb2; } \\
\text { N-terminal GST-tag }\end{array}$ & Dr. Annika Grabbe \\
\hline GST-Grb2 [nSH3] & $\begin{array}{l}\text { N-terminal SH3 domain of mouse Grb2; } \\
\text { N-terminal GST-tag }\end{array}$ & Dr. Annika Grabbe \\
\hline
\end{tabular}

\subsubsection{Biotinylated peptides}

Table 7.6: Biotinylated peptides

\begin{tabular}{|l|l|l|}
\hline Peptide & Supplier/reference & application \\
\hline \hline Gastric Precursor (Tyr87) & Cell signaling Technology & Kinase Assay \\
\hline Signal Transduction Peptide & Cell signaling Technology & Kinase Assay \\
\hline Ig- $\alpha$-pPepI & Engels, 2005 & AP \\
\hline
\end{tabular}

\subsubsection{Bacterial strains}

The following E.coli strains were used for the production of expression vectors, of pCRTopo plasmids, or expression of recombinant proteins (BL21), respectively. The generation of competent bacteria and their transformation are described in 7.5.1.1 and 7.5.1.2.

Table 7.7: Bacteria strains

\begin{tabular}{|c|c|c|}
\hline strain & genotype & supplier \\
\hline BL21 DE3 & $\mathrm{F}^{-}$ompT hsdS ${ }_{\mathrm{B}}\left(\mathrm{r}_{\mathrm{B}}^{-} \mathrm{m}_{\mathrm{B}}^{-}\right)$gal dcm (DE3) & Invitrogen \\
\hline DH5 $\alpha$ & $\begin{array}{l}\mathrm{F}^{-} \text {endA1 glnV44 thi-1 recA1 relA1 gyrA96 deoR } \\
\text { nupG } \Phi 80 \mathrm{~d} \text { lacZ } \Delta \mathrm{M} 15 \Delta(\text { lacZYA-argF }) \mathrm{U} 169 \\
\left.\text { hsdR17( } \mathrm{r}_{\mathrm{K}}^{-} \mathrm{m}_{\mathrm{K}}^{+}\right), \lambda^{-}\end{array}$ & Promega \\
\hline Top10F' & 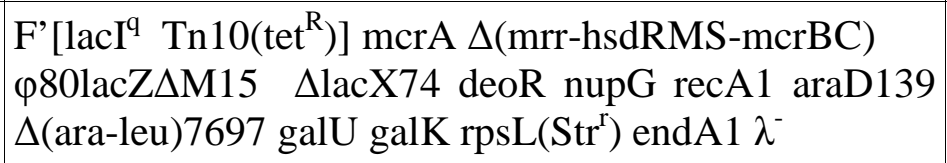 & Invitrogen \\
\hline XL1 Blue & $\begin{array}{l}\text { endA1 gyrA96(nalR) thi-1 recA1 relA1 lac glnV44 } \\
\mathrm{F}^{\prime}\left[:: \operatorname{Tn} 10 \text { proAB+ } \operatorname{lacI}^{\mathrm{q}} \quad \Delta(\mathrm{lacZ}) \mathrm{M} 15\right] \text { hsdR17( } \mathrm{r}_{\mathrm{K}}^{-} \\
\left.\mathrm{m}_{\mathrm{K}}^{+}\right)\end{array}$ & Stratagene \\
\hline
\end{tabular}




\subsubsection{Cell lines}

DT40 (ATCC number: CRL-2111):

The DT40 cell line is derived from an avian leukosis virus (ALV) - induced bursal lymphoma of the bursa fabricii of a "Hyline SC" chicken (BABA and HUMPHRIES, 1984; BABA et al., 1985). The original lymphoma was induced by a viral infection of a one day old chicken with Rous associated virus 1 (RAV-1). DT40 cells express IgM on their surface and undergo IgL gene conversion during in vitro cell culture (BUERSTEDDE et al., 1990; KIM et al., 1990). Stimulation of DT40 by anti-chicken IgM antibodies leads to apoptosis, mimicking the elimination of self-reactive B cells (TAKATA et al., 1995). The mot unique feature of DT40 cells is the high ratio of targeted to random integration of exogenous DNA (reviewed in SONODA et al., 2001; WINDING and BERCHTOLD, 2001).

In table 7.8 the DT40 knock-out cell lines used in this thesis are listed.

Table 7.8: DT40 knock-out cell lines

\begin{tabular}{|c|l|}
\hline DT40 knock out cell lines & Reference \\
\hline$d o k-3^{--}$ & STORK et al., 2007 \\
\hline$g r b 2^{--}$ & HASHIMOTO et al., 1998 \\
\hline$l y n^{--}$ & TAKATA et al., 1994 \\
\hline$s y k^{--}$ & TAKATA et al., 1994 \\
\hline$s l p-65^{--}$ & YASUDA et al., 1999b 2000 \\
\hline$c b l^{--}$ & MAEDA et al., 1998 \\
\hline$s h p-1^{--}$ & MAEDA et al., 1998 \\
\hline$s h p-2^{--}$ & INABE et al., 2002 \\
\hline$v a v 3^{--}$ & ONO et al., 1997 \\
\hline$s h i p{ }^{--}$ & this thesis \\
\hline$l y n n^{-/} / d o k-3^{--}$ & this thesis \\
\hline$d o k-3^{--} / s y k^{-/-}$ &
\end{tabular}

\section{Platinum-E (Plat-E):}

Plat-E cells are a third generation retrovirus packaging cell line based on the HEK293T cell line. In Plat-E cells, the viral structural genes gag-pol and env of the moloney murine leukemia virus (MMLV) are expressed under the control of the EF1a promoter, which is 
100-fold more potent that the MuLV-LTR promoter in HEK293T cells. Both gag-pol and env were joined to genes encoding selectable markers (Blasticidin and Puromycin) via an internal ribosome entry site (IRES) (MORITA et al., 2000)

\subsubsection{Solutions, buffers and media}

The composition of all solutions and buffers are listed in the sections in which the corresponding experimental procedures are described. All solutions and buffers are aqueous solutions and stored at room temperature unless otherwise indicated. If solutions and buffers had to be autoclaved it is indicated. Autoclaving of liquids was carried out at $125{ }^{\circ} \mathrm{C}$ for $30 \mathrm{~min}$. RPMI medium was already endotoxin tested and filter sterilized.

The following common buffers were used:

PBS $140 \mathrm{mM} \mathrm{NaCl} ; 2.7 \mathrm{mM} \mathrm{KCl} ; 1.5 \mathrm{mM} \mathrm{KH} \mathrm{PO}_{4} ; 8.6 \mathrm{mM}$ $\mathrm{Na}_{2} \mathrm{HPO}_{4}$

Tris/HCL .0.5-1.5 M Tris; adjust $\mathrm{pH}$ to $6.8-8.8$ with $\mathrm{HCL}$

TE buffer 10 mM Tris/HCL, pH 8.0; 1 mM EDTA, pH 8.0

\subsection{Additional Material}

Tissue culture equipment (dishes, pipettes, tubes, etc.) Greiner, Nunc

Electroporation cuvettes (4mm gap) PeqLab

ultrafiltration spin column

Sartorius

Nitrocellulose filter Hybond ECL ${ }^{\mathrm{TM}}$

Amersham Biosciences

Prestained Protein Marker, Broad Range (6.5-175 kDa)

GeneRulerтм 1 kb DNA ladder

New England Biolabs

Protease Inhibitor Cocktail (P 2714)

MBI Fermentas

Glutathion Sepharose® 4Fast Flow

Sigma-Aldrich

Strep-Tactin Superflow matrix

GE Healthcare

D-Desthiobiotin elution buffer

Iba BioTAGnology

Protein A/G-Agarose

Iba BioTAGnology

Western blotting filter paper

Santa Cruz Biotechnology

Transfection reagent Trans-IT

Schleicher \& Schell

ABTS

Mirus

Roche 


\subsection{Instruments}

Thermomixer comfort

Eppendorf

BioPhotometer

Eppendorf

$\mathrm{pH}$ meter $\mathrm{pH}$ level 1

inoLab $^{\circledR}$

PCR-cycler mastercycler epgradient \& personal

Eppendorf

rotator

Schütt

Centrifuges

SORVALL® RC 3B Plus and SORVALL® RC 26 Plus

Servall $^{\circledR}$

refrigerated centrifuge $5417 \mathrm{R}$

Eppendorf

Multifuge 3 S-R

Heraeus

Elektrophoresis systems

SDS- PAGE

Agarose gel electrophoresis

T70/T77 semi-dry transfer unit

Chemi Lux Imager

Gel Imager

Unitron plus (bacterial incubator)

Kelvitron@t (bacteria incubator)

Gene Pulser® II Electroporation System

HERAcell 150 (cell culture incubators)

HERAsafe KS18 (cell culture bench)

FACSCalibur

LSRII

Laser Scanning Sectral Confocal Microscope TCS SP2
Amersham, Biorad

PeqLab

Amersham Biosciences

Intas

Intas

INFORS

Heraeus

Biorad

Heraeus

Heraeus

Becton Dickenson

Becton Dickenson

Leica

\subsection{Software}

CellQuest; FlowJo ( $\mathrm{Ca}^{2+}$ mobilization analysis)

CSX-1400M Camera Controller (Chemi Lux Imager)

Gel documentation software (Gel Imager)

Adobe $^{\circledR}$ Photoshop ${ }^{\circledR}$ CS2 (image editing)

pDRAW 3.1 (in silico DNA analysis)

CorelDraw, Image J

MS Office, Endnote 7 


\subsection{Experimental Procedure}

\subsubsection{Methods in molecular biology}

\subsubsection{Generation of transformation competent E.coli bacteria}

For generation of transformation competent bacteria an overnight culture of the accordingly bacteria culture was cultivated in $150 \mathrm{~mL} \mathrm{LB}$ medium up to an $\mathrm{OD}_{600 \mathrm{~nm}}$ of 0.45-0.55. After $10 \mathrm{~min}$ incubation on ice, bacteria were centrifuged with $2000 \mathrm{~g}$ for 10 min at $4{ }^{\circ} \mathrm{C}$. The supernatant was removed and the pellet was resuspended in $30 \mathrm{~mL}$ ice cold TFB I buffer. After 10 min incubation on ice, cells were centrifuged again and afterwards resuspended in $6 \mathrm{~mL}$ ice cold TFB II buffer. $50 \mu \mathrm{L}$ portions were transferred to $1.5 \mathrm{~mL}$ tubes, flash frozen with liquid nitrogen and stored at $-80{ }^{\circ} \mathrm{C}$.

LB medium $10 \mathrm{~g} / \mathrm{L}$ tryptone; $5 \mathrm{~g} / \mathrm{L}$ Yeast Extract; $10 \mathrm{~g} \mathrm{NaCl}$; add $1000 \mathrm{~mL}$ $\mathrm{ddH}_{2} \mathrm{O}$, autoclave, store at $4{ }^{\circ} \mathrm{C}$

TFB I buffer..............50 mM MnCl $2 ; 100 \mathrm{mM} \mathrm{KCl;} 10$ mM CaCl $2 ; 30$ mM KOAc; pH $6.8 ; 15 \%$ (v/v) glycerole; adjust to $\mathrm{pH} 6.1$ with HOAc; autoclaved; store at $4{ }^{\circ} \mathrm{C}$

TFB II buffer $75 \mathrm{mM} \mathrm{CaCl} 2 ; 10 \mathrm{mM} \mathrm{KCl} ; 10 \mathrm{mM}$ MOPS; $15 \%$ (v/v) glycerol; adjust to $\mathrm{pH} 7.0$ with $\mathrm{KOH}$; autoclaved; store at $4{ }^{\circ} \mathrm{C}$

\subsubsection{Transformation of competent E.coli bacteria}

Bacteria were thawed on ice for $10 \mathrm{~min}$. An appropriate amount of plasmid DNA or $10 \mu \mathrm{L}$ of ligation reaction were added. After mixing carefully by tapping, cells were incubated 30 min on ice and heat-shocked for 5 seconds at $42{ }^{\circ} \mathrm{C}$. The bacteria were returned on ice for 2 min. $500 \mu \mathrm{L}$ of fresh LB medium was added and cells were incubated at $37^{\circ} \mathrm{C}$ and 400 rpm for $15 \mathrm{~min}$. After centrifugation for $3 \mathrm{~min}$ at $300 \mathrm{~g}$, cells were resuspended in $100 \mu \mathrm{l}$ LB medium and plated on LB plates containing the appropriate amount of antibiotic.

Cells transfected with pCRII Topo vectors were plated on plates additionally containing IPTG and X-gal for blue/white screening. Plates were incubated at $37{ }^{\circ} \mathrm{C}$ for at least $16 \mathrm{~h}$.

LB/agar $15 \mathrm{~g}$ agar in $1000 \mathrm{~mL} \mathrm{LB}$; autoclaved; store at $4{ }^{\circ} \mathrm{C}$ X-Gal/IPTG plates LB/ampicillin/agar, supplemented with $80 \mu \mathrm{g} / \mathrm{mL}$ X-Gal and $20 \mathrm{mM}$ IPTG; store at $4{ }^{\circ} \mathrm{C}$ 
Table 7.9: Selection of bacteria

\begin{tabular}{|c|l|}
\hline antibiotic & final concentration \\
\hline \hline Ampicillin (Amp) & $50-100 \mu \mathrm{g} / \mathrm{mL}$ \\
\hline Kanamycin (Kana) & $30-50 \mu \mathrm{g} / \mathrm{mL}$ \\
\hline
\end{tabular}

\subsubsection{Isolation of plasmid DNA}

For isolation of plasmid DNA $5 \mathrm{~mL} \mathrm{LB} / \mathrm{Amp}$ or LB/Kana were incubated with a single bacterial colony over night at $37{ }^{\circ} \mathrm{C}$ and $180 \mathrm{rpm}$. Plasmid DNA was isolated out of $4 \mathrm{~mL}$ culture by using the Invisorb ${ }^{\circledR}$ Spin plasmid Mini Two (Invitek) following manufactures instructions. For larger amounts of DNA 100-200 mL LB/Amp were inoculated with a $4 \mathrm{~mL}$ day culture of a single bacterial colony and grown over night at $37^{\circ} \mathrm{C}$ and $180 \mathrm{rpm}$. Plasmid preparation then was carried out with the Pure Yield ${ }^{\mathrm{TM}}$ Plasmid Midiprep System (Promega) as by manufactures manual.

\subsubsection{Isolation of genomic DNA from tissue culture cells}

DT40 cells were washed once with PBS and resuspended in tag-lysis buffer at a density of $5 \cdot 10^{6}$ cells $/ \mathrm{mL}$. The cell suspension was incubated at $56{ }^{\circ} \mathrm{C}$ for $3 \mathrm{~h}$. Proteinase $\mathrm{K}$ was heat-inactivated by incubation at $95{ }^{\circ} \mathrm{C}$ for $15 \mathrm{~min}$. The genomic DNA within the cell lysates was directly used as template for PCR.

tag-buffer $10 \mathrm{mM}$ Tris/HCl, pH 8.0; $50 \mathrm{mM} \mathrm{KCl;} 0.45 \%$ NP-40; $0.45 \%$

Tween-20; $100 \mu \mathrm{g} / \mathrm{mL}$ Proteinase $\mathrm{K}$; store at $4{ }^{\circ} \mathrm{C}$

\subsubsection{Digestion of DNA with restriction endonucleases}

For sequence-specific DNA cleavage restriction endonucleases were use, which recognize and cleave specific palindrome sequences inside of the DNA. Restriction endonucleases were applied by NEB and used as by manufactures instructions. 


\subsubsection{Dephosphorylation of linearized DNA}

Linearization of Vector-DNA with just on restriction endonuclease can result in relegation. To prevent this, linearized Vector DNA was dephosphorylated at the 5'-end with Calf intestine Phosphatase (CIP, NEB) prior to ligation. Therefore $0.5 \mu \mathrm{L}$ CIP were directly added to the restriction digest and incubated for $45 \mathrm{~min}$ at $37^{\circ} \mathrm{C}$.

\subsubsection{Ethanol precipitation of linearized DNA}

For DNA precipitation $1 / 10$ volume of $5 \mathrm{M} \mathrm{NaCl}$ and 2.5 volumes ice cold Ethanol $(100 \%)$ were added to the digestion reaction. The mixture was incubated at $-80{ }^{\circ} \mathrm{C}$ for 10 min and subsequently centrifuged at maximum speed and $4^{\circ} \mathrm{C}$ for $15 \mathrm{~min}$. Supernatant was removed and the pellet was air-dried for $30 \mathrm{~min}$. The Pellet was dissolved in $1 \mu \mathrm{l} \mathrm{ddH}_{2} \mathrm{O}$ per $1 \mu \mathrm{g}$ linearized DNA over night at $4^{\circ} \mathrm{C}$.

\subsubsection{Ligation of DNA}

For ligation of linearized vectors and DNA fragment (Inserts) T4 Ligase (NEB) was used. This enzyme catalysis the formation of a phosphodiesther bond between 3'-OH and 5'-P ends in dsDNA. For ligation of cohesive ends a molar ration of 1:3 (vector: insert DNA) was used, for ligation of blunt ends a molar ratio of 1:5. In addition $0.5 \mu \mathrm{L}$ of T4 DNA ligase (NEB) and the appropriate volume of 10-fold reaction buffer were added. If necessary, the mixture was brought up to $10 \mu \mathrm{L}$ with $\mathrm{dH}_{2} \mathrm{O}$. To check the ability of the vector DNA for religation a reaction was set up without the addition of insert DNA. Reactions were incubated at $22{ }^{\circ} \mathrm{C}$ for at least $1 \mathrm{~h}$ and used directly for transformation of competent bacteria.

\subsubsection{Polymerase chain reaction $(\mathrm{PCR})$}

The Polymerase chain reaction (PCR) is a method for the in vitro amplification of specific DNA fragments (SAIKI et al., 1985; MULLIS et al., 1986; MULLIS and FALOONA, 1987).

\section{$\underline{\text { Standard PCR }}$}

Amplification of DNA via PCR was performed using the proofreading polymerase $P f u$ (Promega) for cDNA amplification or the non-proofreading polymerase Taq (Qiagen) for analytic PCRs. Reactions were set up in a volume of $20 \mu \mathrm{l}$ using the components as described in Table 7.10. 
Table 7.10: Standard PCR

\begin{tabular}{|c|c|}
\hline component & concentration \\
\hline DNA & $300-500 \mathrm{ng}$ \\
\hline 5'- primer & $0.2 \mu \mathrm{M}$ \\
\hline 3'- primer & $0.2 \mu \mathrm{M}$ \\
\hline dNTPs & $2.5 \mathrm{mM}$ (each) \\
\hline buffer & 1 -fold \\
\hline polymerase & $0.06 \mathrm{U}$ \\
\hline
\end{tabular}

The cycling parameters were set up accordingly to the annealing temperatures of the oligonucleotides as shown in Table 7.11.

Table 7.11: Summary of cycling parameters

\begin{tabular}{|c|c|c|c|}
\hline reaction & $\mathrm{T}\left[{ }^{\circ} \mathrm{C}\right]$ & time & cycles \\
\hline initial denaturation & $94-98$ & 1-3 min & 1 \\
\hline denaturation & $94-98$ & $30-60 \mathrm{~s}$ & \multirow{3}{*}{$25-30$} \\
\hline annealing & $58-68$ & $30-60 \mathrm{~s}$ & \\
\hline elongation & $\begin{array}{l}68 \text { (Pfu) } \\
72 \text { (Taq) }\end{array}$ & $\begin{array}{c}0.5 \mathrm{~kb} / \mathrm{min} \\
1 \mathrm{~kb} / \mathrm{min}\end{array}$ & \\
\hline final elongation & $\begin{array}{l}68 \text { (Pfu) } \\
72 \text { (Taq) }\end{array}$ & $5-10 \min$ & 1 \\
\hline & 12 & $\infty$ & \\
\hline
\end{tabular}

PCR products were analyzed and isolated via agarose gel electrophoresis (see 7.5.1.11) or saved by using Topo-TA cloning (see 7.5.1.10)

\section{$\underline{\text { Site directed mutagenesis }}$}

Site-directed mutagenesis was used to introduce specifically mutations into a dsDNA. Therefore two synthetic oligonucleotides containing the desired mutation (substitution or deletion) surrounded by $8-15$ bases of correct sequence on both sites were used. During PCR the mutagenesis is introduced into each newly generated duplicate. Reaction were prepared as indicated in table 7.11. Following PCR, samples were treated with $1 \mu \mathrm{DpnI}$ for $45 \mathrm{~min}$ at $37{ }^{\circ} \mathrm{C}$. This endonuclease specifically cuts methylated and hemimethylated DNA. Since the tenplate DNA for PCR is isolated from E.coli strains, and this DNA is 
ethylated, all parental DNA is digested by DpnI. The remaining, mutated DNA is then transformed into competent bacteria (see 7.5.2.1).

\section{Overlap extension PCR}

Overlap-Extension PCR can be used to fuse two DNA-Fragments which have an overlapping area. In a first step the fragments were amplified by the use of primers which produce these complementary areas. Therefore primers were designed the way that the 5 '-area of the 3'-fragment is complementary with the 3'-area of the 5'-fragment. In a second PCR these fragments together with the 3'-primer of the 3'-fargment and the 5'-primer of the 5'-fragment were used. PCR was performed as described for standard PCR (table 7.10) yet using instead of Vector-DNA the fragments as templates.

\subsubsection{T/A cloning}

The polymerase Taq adds additional adenosine residues at the 3'-end of PCR products. The Topo-T/A cloning vector has overhanging thymidine residues at its 5'-end which allows a direct ligation of the PCR product into the vector. During this thesis the TOPO TA cloning ${ }^{\circledR}$ kit with the vector $\mathrm{pCR}^{\circledR} \mathrm{II}-\mathrm{TOPO}^{\circledR}$ from Invitrogen was used.

PCR products that had been generated using $P f u$ polymerase were first treated with Taq. Therefore the PCR product was purified, eluted in $20 \mu \mathrm{l}$ elution buffer (see 7.5.1.12) and incubated with $0.5 \mu \mathrm{l} \mathrm{Taq-Polymerase,} 2.5 \mu \mathrm{l}$ Taq buffer and $1 \mu \mathrm{ldNTPs}(10 \mathrm{mM})$. The samples were incubated for $10 \mathrm{~min}$ ant $72{ }^{\circ} \mathrm{C}$. Rest was performed following manufactures instructions.

\subsubsection{Agarose gel electrophoresis}

Agarose Gel electrophoresis is used for separation of DNA-Fragments due to their size, to characterize them and if necessary to isolate single fragments. Therefore $0.7-2 \%$ of agarose $(\mathrm{w} / \mathrm{v})$ was dissolved in TAE buffer by heating in a microwave and $0.5 \mu \mathrm{g} / \mathrm{mol}$ ethidium bromide were added. The solution was decanted in a sealed gel casting chamber. Samples were mixed with an appropriate volume of 6-fold DNA loading dye. Together with a DNA molecular weight standard (1 kb DNA gene ruler, MBI Fermentas) electrophoresis was performed with $5 \mathrm{~V} / \mathrm{cm}$ distance between electrodes. Visualization of stained fragments was carried out with UV- irradiation at a wavelength of $312 \mathrm{~nm}$.

6-fold DNA loading buffer........10 mM Tris/HCl, pH 8.0; 1 mM EDTA; $0.25 \%$ (w/v)

bromophenolblue; $15 \%$ (w/v) Ficoll 
TAE buffer (50-fold). $.2 \mathrm{M}$ Tris/acetic acid; $50 \mathrm{mM}$ EDTA pH 8,0

\subsubsection{Isolation of DNA-Fragments from agarose gels}

Isolation of DNA-fragments from agarose gels was done with the NucleoSpin ${ }^{\circledR}$ Extract II Kit (Macherey-Nagel) by manufactures instructions.

\subsubsection{DNA-Sequencing}

DNA-Sequencing was performed following the dideoxy method (SANGER et al., 1977). Analyzes were carried out by MWG Biotech (Ebersberg, Germany) and SeqLab (Göttingen, Germany).

\subsubsection{Cell culturing}

Supplementary factors within fetal calf serum (FCS) and chicken serum (CS) were heat inactivated at $56{ }^{\circ} \mathrm{C}$ for $30 \mathrm{~min}$ before usage. The cell density was determined using a Neubauer chamber slide. Centrifugation of eukaryotic cells was done with a refrigerated centrifuge for $4 \mathrm{~min}$ at $300 \mathrm{~g}$ and $4{ }^{\circ} \mathrm{C}$ (unless otherwise describes).

\subsubsection{Cultivation of eukaryotic cells}

All cell lines were cultivated in $5 \% \mathrm{CO}_{2}$ humidified atmosphere at $37{ }^{\circ} \mathrm{C}$ in the indicated media.

DT40 medium.......RPMI 1640 + GlutaMax; $10 \%$ FCS; 100 U/ml Penicillin; $100 \mu \mathrm{g} / \mathrm{mL}$ Streptomycin; $50 \mu \mathrm{M}$ B-Mercaptoethanol

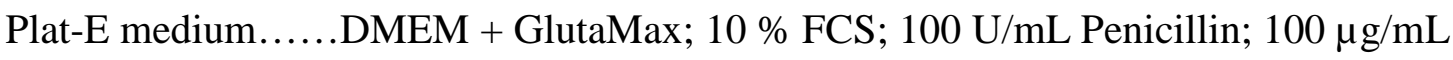
Streptomycin; $10 \mu \mathrm{g} / \mathrm{mL}$ Blasticidin; $2 \mu \mathrm{g} / \mathrm{mL}$ Puromycin SILAC medium......RPMI 1640 minus L-Lysine and L-Arginine; 10 \% FCS; 1 mM pyruvate, $4 \mathrm{mM}$ glutamine; 'Heavy' and 'light' medium were prepared by adding $0.115 \mathrm{mM}{ }^{13} \mathrm{C}_{6}{ }^{15} \mathrm{~N}_{4} \mathrm{~L}$-arginine and $0.275 \mathrm{mM} 13 \mathrm{C}_{6} 15 \mathrm{~N}_{2} \mathrm{~L}$ lysine (Sigma Isotec), or the corresponding non-labeled amino acids (Sigma), respectively. 


\subsubsection{Thawing and freezing of cells}

Eukaryotic cells were rapidly thawed at $37{ }^{\circ} \mathrm{C}$ and directly transferred into $7 \mathrm{~mL}$ fresh medium. Cells were harvested, resuspended in $7 \mathrm{~mL}$ fresh medium and transferred to a fresh dish.

For freezing, $1 \cdot 10^{7}$ cells were harvested, resuspended in $1 \mathrm{~mL}$ freezing medium and transferred to a cryo-tube. Cells were first put to $-80{ }^{\circ} \mathrm{C}$ for $24 \mathrm{~h}$ and then transferred to $-140{ }^{\circ} \mathrm{C}$ for long term storage.

freezing medium $.90 \%$ FCS; $10 \%$ DMSO

\subsubsection{Transfection of DT40 cells by electroporation}

$1 \cdot 10^{7}$ cells for each infection were washed twice with PBS. 15-30 ng linearized DNA were submitted to an electroporation cuvette (4 mm electrode gap, Peqlab Biotechnology $\mathrm{GmbH}$, Germany). Cells were resuspended in $700 \mu \mathrm{L}$ PBS and transferred to the cuvette. After incubation on ice for $30 \mathrm{~min}$ electroporation was performed at $550 \mathrm{~V}$ and $25 \mu \mathrm{F}$ or 260V and $960 \mu \mathrm{F}$. Cells were again incubated on ice for $15 \mathrm{~min}$ and subsequently transferred to $10 \mathrm{~mL}$ fresh DT40 medium. After $24 \mathrm{~h}$ incubation at $37{ }^{\circ} \mathrm{C}$ and $5 \% \mathrm{CO}_{2}$, cells were resuspended in fresh medium containing an appropriate amount of antibiotic (see table 7.12). Cells were plated on 96-well-plates with a volume of $200 \mu 1$ per well. After 7-10 days transfectants were visible and transferred to 24-well plates.

Table 7.12: Selection of DT40

\begin{tabular}{|l|l|}
\hline \multicolumn{1}{|c|}{ antibiotic } & final concentration \\
\hline Puromycin & $1 \mu \mathrm{g} / \mathrm{mL}$ \\
\hline Blasticidin S & $50 \mu \mathrm{g} / \mathrm{mL}$ \\
\hline Bleomycin & $100 \mu \mathrm{g} / \mathrm{mL}$ \\
\hline Hygromycin B & $1.5 \mathrm{mg} / \mathrm{mL}$ \\
\hline
\end{tabular}

\subsubsection{Transfection of Plat-E cells for production of recombinant viruses}

Plat-E cells were used as packaging cell lines for the production of recombinant, replication-incompetent retroviruses. These viruses then could be used for infection of 
B lymphocytes. Therefore Plat-E cells were splitted $24 \mathrm{~h}$ prior to infection to reach a confluence of 50-70\%. For transfection the following components were mixed in the given order:

$200 \mu 1$ RPMI w/o supplements

$7.5 \mu 1$ Trans-IT (Mirus)

$0.7 \mu \mathrm{g}$ pHCMV-VSV-G

$2 \mu \mathrm{g}$ retroviral expression vector

The components were gently mixed by tapping and left at room temperature for 15-45 min. The medium of the Plat-E cells was exchanged by DT40 medium and transfection reaction was added dropwise. After $48 \mathrm{~h}$ incubation at $37{ }^{\circ} \mathrm{C}$ and $5 \% \mathrm{CO}_{2}$ the supernatant containing the virus was used for transduction.

\subsubsection{Transfection of DT40 cells with recombinant viruses}

Infection of DT40 was performed by using a retroviral gene transfer system. This is based on the separately provision of the retroviral expression vector containing the cDNA on the one hand and the gag-pol and env genes by the packaging cell line (Plat-E) on the other hand. The used retroviral expression vector pMSCV provides the target gene, the gene for the selection marker, the packaging signal $\psi$ and the 5' - and 3'- LTR (long terminal repeats), which are important for reverse transcription, integration and transcription. Gagpol and env are coding for viral proteins which are important for packaging as well as for processing of the RNA and integration in the genome of the target cell. The env gene in Plat-E leads to production of ecotropic viruses. Co-transfection of the packaging cell line with the Glycoprotein of the vesicular stromatitis virus (VSV-G) leads to production of viruses which are independent of receptors on the target cell and hence can be used for infection of non-ecotropic cells.

For infection of DT40 cells with VSV-G pseudo-typed recombinant retroviruses (see 7.5.2.4), $1.5 \mathrm{~mL}$ fresh DT40 medium and $45 \mu \mathrm{l}$ of a polybrene stock solution (final concentration $3 \mu \mathrm{g} / \mathrm{mL}$ ) were mixed and given to a $6 \mathrm{~cm}$ dish. The retroviral supernatant was centrifuged at $300 \mathrm{~g}$ and $4{ }^{\circ} \mathrm{C}$ for $4 \mathrm{~min} .1 \cdot 10^{6}$ cells were harvested, resuspended in $3 \mathrm{~mL}$ retroviral supernatant and transferred to the dish. After 24 hours the cells were harvested and resuspended in $4 \mathrm{~mL}$ fresh DT40 medium. Following additional $24 \mathrm{~h}$ the antibiotic for selection was added to the cells (see table 7.12). All manipulations of pseudo- 
typed retroviruses were performed in compliance with the S2 standard and safety instructions.

polybrene stock solution. $3 \mathrm{mg} / \mathrm{mL}$ polybrene (hexadimethrine bromide) in PBS; sterile filtered; freshly prepared prior to each Infection

\subsubsection{6 $\mathrm{Ca}^{2+}$ mobilization analysis}

$1 \cdot 10^{6}$ cells were resuspended in $700 \mu \mathrm{R}$ RMI containing $5 \%$ FCS. A dye solution containing $1 \mathrm{mM}$ Indo-1-AM final and $5 \%$ Pluronic F-127 was added and cells were incubated for $25 \mathrm{~min}$ at $30{ }^{\circ} \mathrm{C}$. The cells were diluted by adding $700 \mu \mathrm{l}$ pre-warmed RPMI containing $10 \% \mathrm{FCS}$ and incubated for another $10 \mathrm{~min}$ at $37^{\circ} \mathrm{C}$. Cells were washed with $1 \mathrm{~mL} \mathrm{Ca}{ }^{2+}$-containing Krebs-Ringer, resuspended in $300 \mu \mathrm{l}$ of $\mathrm{Ca}^{2+}$-containing KrebsRinger solution and kept at $25{ }^{\circ} \mathrm{C}$ until measurement.

For measuring the extracellular $\mathrm{Ca}^{2+}$ flux independently of the $\mathrm{Ca}^{2+}$ flux across the plasma membrane, cells were harvested and resuspended in $300 \mu$ l EGTA-containing KrebsRinger solution prior to measurement.

Krebs-Ringer solution $10 \mathrm{mM}$ HEPES, pH 7.0; $140 \mathrm{mM} \mathrm{NaCl} ; 4$ mM KCl; 1 $\mathrm{mM} \mathrm{MgCl} 2 ; 10 \mathrm{mM}$ glucose

$\mathrm{Ca}^{2+}$-containing. $+1 \mathrm{mM} \mathrm{CaCl}_{2}$

EGTA-containing +0.5 mM EGTA

Pluronic F-127 stock $5 \%(\mathrm{w} / \mathrm{v})$

Indo-1-AM stock. $1 \mathrm{mM}$ in DMSO; store at $-20{ }^{\circ} \mathrm{C}$

\subsubsection{Confocal laser scanning microscopy}

Confocal laser scanning microscopy of the TSH2-Dok-3/GFP expressing cells (see section 4.1.3) was performed on $1 \cdot 10^{6}$ harvested cells, washed twice with $\mathrm{Ca}^{2+}$-containing KrebsRinger solution. Cells were resuspended in $400 \mu \mathrm{l}$ Krebs-Ringer solution and transferred to 4-well chamber slides (Lab-Tek ${ }^{\mathrm{TM}}$, Nunc). Following sedimentation cells were BCRstimulated using $2 \mu \mathrm{g} / \mathrm{mL}$ M4 and subjected to confocal laser scanning microscopy using the Leica TCS SP2 microscope (kindly performed by M. Engelke; Leica objective HCX PL APO 63.0x1.32 OIL UV; zoom 1-5). Images were exported to Adobe ${ }^{\circledR}$ Phostoshop ${ }^{\circledR}$ CS2 


\subsubsection{Biochemical Methods}

\subsubsection{Production of recombinant GST-Fusion proteins}

For production of recombinant GST fusion proteins in a high range, $500 \mathrm{~mL}$ of LB/Amp medium were inoculated with $5 \mathrm{~mL}$ of an overnight culture of the corresponding E.coli BL21 strain till an optical density $\left(\mathrm{OD}_{600}\right)$ of 0.6-0.8 was reached. Expression of fusion proteins was induced by adding IPTG in a final concentration of $100 \mu \mathrm{M}$ and cells were incubated for 2-3 h depending on the fusion protein to be expressed. Cells were harvested by centrifugation at $3000 \mathrm{~g}$ and $4{ }^{\circ} \mathrm{C}$ for $15 \mathrm{~min}$.

For lysis cells were resuspended in $20 \mathrm{~mL}$ bacteria lysis buffer and incubated on ice for $15 \mathrm{~min}$. After lysing cells by sonicating them 6 times for $30 \mathrm{~s}$, Triton X-100 was added to a final concentration of $1 \%$. The lysate was incubated on ice for $10 \mathrm{~min}$ and centrifuged at $5000 \mathrm{~g}$ and $4{ }^{\circ} \mathrm{C}$ for $20 \mathrm{~min}$. The supernatant was transferred to two $15 \mathrm{~mL}$ falcons and $100 \mu \mathrm{L}$ of Gluatthion Sepharose ${ }^{\circledR}$ beads (Amersham Biosciences) were added to each falcon. The lysate was rotated over night at $4{ }^{\circ} \mathrm{C}$ and beads were washed three times with $5 \mathrm{~mL}$ Triton X-100-containing lysis buffer. Beads were resuspended in $100 \mu 1$ lysis buffer and transferred to a fresh tube.

For interaction studies in far western approaches (7.5.3.10) proteins were eluted from the beads by adding $100 \mu \mathrm{L}$ elution buffer for $15 \mathrm{~min}$. Beads were precipitated by centrifugation and the supernatant, containing the fusion protein, was transferred to a new tube.

For quantification of bound or eluted protein the samples were subjected to SDS-PAGE together with a BSA standard and visualized by CBB staining (7.5.3.8)

lysis buffer..........................50 mM Tris/HCl pH 7.4; 150 mM NaCl; 5 mM

DTT; protease inhibitor

Triton X-100-containing................to final $1 \%$

elution buffer.......................50 mM Tris/HCl pH 8.0; 10 mM Glutathion

\subsubsection{Stimulation of DT40 cells via the BCR}

Prior to stimulation cells were washed once with PBS. Cells were then resuspended in RPMI 1640 medium without supplements in a density of $1-4 \cdot 10^{7}$ cells $/ \mathrm{mL}$ and incubated at $37{ }^{\circ} \mathrm{C}$ and $400 \mathrm{rpm}$ for $20 \mathrm{~min}$. Cells were stimulated with $2 \mu \mathrm{g} / \mathrm{mL} \mathrm{M} 4$ antibody and after incubation at $37{ }^{\circ} \mathrm{C}$ for 3-5 min harvested and resuspended in $1 \mathrm{~mL}$ lysis buffer. For 
lysis cells were rotated for 1 hour at $4{ }^{\circ} \mathrm{C}$. Lysates were cleared from cell debris by centrifugation at $4{ }^{\circ} \mathrm{C}$ for $15 \mathrm{~min}$ at maximum speed. The cleared cellular lysates (CCL) were transferred to a fresh tube and either directly mixed with accordingly amounts of 5-fold SDS sample buffer or used for immuno- or affinity precipitation experiments.

lysis buffer $20 \mathrm{mM}$ Tris/HCl, pH 7.5; $150 \mathrm{mM} \mathrm{NaCl} ; 0.5$ mM EDTA; $10 \mathrm{mM} \mathrm{NaF} ; 10 \mu \mathrm{M} \mathrm{Na}_{2} \mathrm{MoO}_{4} ; 1 \mathrm{mM} \mathrm{Na}_{3} \mathrm{VO}_{4}$; $1 \%$ detergent (see below); protease inhibitor detergent.......................NP-40 or laurylmaltosid 5-fold SDS Sample buffer......280 mM Tris/HCl pH 6.8; $10 \%$ (w/v) SDS; $30 \%$ (v/v) Glycerin; 500 mM DTT; 0,012\% (w/v) bromphenol blue

\subsubsection{Affinity purification experiments}

For affinity purification experiments CCL of unstimulated and stimulated cells were incubated with either GST fusion proteins over night (7.5.3.2) or with biotinylated peptides for $1 \mathrm{~h}$. The beads were washed three times with lysis buffer. Subsequently 30-50 $\mu 1$ of 2-fold SDS sample buffer were added to the pellet and boiled for $3 \mathrm{~min}$ at $95{ }^{\circ} \mathrm{C}$. Samples were separated with SDS-PAGE (7.5.3.7).

2-fold SDS Sample buffer .112 mM Tris/HCl, pH 6.8; $4 \%$ (w/v) SDS; $12 \%$ (v/v) Glycerin; 200 mM DTT; $0.005 \%$ (w/v) bromphenol blue

\subsubsection{Affinity purification upon SILAC (Stable isotope labeling in cell culture)}

Cells were grown at least five days in SILAC medium with either heavy or light isotopes (see 7.5.2.1). For affinity purification of One-STrEP-tagged proteins $1 \cdot 10^{8}$ cells from the respective cultures were BCR-stimulated for $3 \mathrm{~min}$ and lysed. Lysates were polled at a 1:1 ratio and incubated with $200 \mu \mathrm{L}$ of Strep-Tactin Superflow matrix (Iba BioTAGnology) for $1 \mathrm{~h}$ at $4{ }^{\circ} \mathrm{C}$. The immobilized protein was eluted at room temperature with $500 \mu \mathrm{L}$ of D-Desthiobiotin elution buffer (Iba BioTAGnology) and concentrated with ultrafiltration spin columns. 


\subsubsection{Immunoprecipitation experiments}

For immunoprecipitation experiments, CCL of 2-4 $\cdot 10^{7}$ cells were incubated with $0.4-1 \mu \mathrm{g}$ of the antibody for at least $5 \mathrm{~h}$ up to over night. Subsequently $20 \mu \mathrm{L}$ of Protein A/G Plus Agarose (Santa Cruz) were added for $1 \mathrm{~h}$. Beads were washed three times with lysis buffer. For analysis of immunoprecipitates, beads were resuspended in 30-50 $\mu 1$ 2-fold SDS sample buffer and boiled for $3 \mathrm{~min}$ at $95{ }^{\circ} \mathrm{C}$. Samples were separated with SDS-PAGE (7.5.3.7).

\subsubsection{In vitro kinase assay}

For in vitro kinase assay beads from immunoprecipitation experiments were washed additionally two times with kinase buffer. Equilibrated beads were resuspended in $25 \mu \mathrm{L}$ of 2-fold kinase buffer. $25 \mu \mathrm{L}$ of the Substrate/ATP mixture were added and incubated for indicated time points. Reactions were stopped by adding $50 \mu \mathrm{L}$ of stop buffer and $25 \mu \mathrm{L}$ of each reaction was used for ELISA (see 7.5.3.12). $25 \mu \mathrm{L}$ of 4-fold SDS sample buffer were added to the remaining samples and subjected to SDS-PAGE to check amounts of precipitated protein via SDS-PAGE and western blotting.

2-fold kinase buffer $120 \mathrm{mM}$ HEPES, pH 7.5; $10 \mathrm{mM} \mathrm{MgCl}_{2} ; 10 \mathrm{mM}$ $\mathrm{MnCl}_{2} ; 6 \mu \mathrm{M} \mathrm{Na}_{3} \mathrm{VO}_{4} ; 2.5 \mathrm{mM}$ DTT

substrate/ ATP mixture $3 \mu \mathrm{M}$ biotinylated peptide; $20 \mu \mathrm{M}$ ATP

stop buffer. $.50 \mathrm{mM}$ EDTA, $\mathrm{pH} 8.0$

\subsubsection{Intracellular FACS staining for Phosflow ${ }^{\mathrm{TM}}$ analysis}

For intracellular FACS staining cells were directly fixed after stimulation with M4 (see 7.5.3.2). Therefore cells were washed once with washing buffer and incubated $10 \mathrm{~min}$ in 1-fold CellFix (Becton Dickinson). After washing once, cells were incubated 10 min with permeabilization buffer (PermII; Becton Dickinson) and washed again once. For blocking free aldehyde groups, cells were incubated $20 \mathrm{~min}$ with blocking buffer and after centrifugation resuspended directly in $20 \mu \mathrm{l}$ of the fluorophore-conjugated antibody solution. After incubating for 30 min cells were washed twice, resuspended in PBS and subjected to FACS analysis. For each diagram 10,000 cells were monitored on a logarithmic scale. 
washing buffer. $.0 .5 \%$ BSA in PBS

blocking buffer $.1 \%$ BSA in PBS

\subsubsection{SDS polyacrylamide gel electrophoresis (SDS-PAGE) (LAEMMLI, 1970)}

Separation of proteins corresponding to their size was performed by a discontinuous denaturating SDS polyacrylamide gel electrophoresis (SDS-PAGE). Proteins migrate through a polyacrylamide gel matrix in an electric field. SDS is an anionic detergent which occupies the protein with a negative net charge by binding and denaturating it. Thus, the protein migrates, just accordingly to its size, not to its innate charge, through the electric field.

The final acrylamide concentration was 8-12.5\% in separating and $5 \%$ in the stacking gels. The PAGE was performed in a vertical electrophoresis chamber at 10-15 mA for stacking and 20-35 mA for separating gels. Prestained protein marker (6.5-175 kDa; NEB) was used as standard. Afterwards gels were subjected to Coomassie staining (see 7.5.3.9), western blot analysis (see 7.5.3.10), or far western analysis (see 7.5.3.11).

SDS running buffer $25 \mathrm{mM}$ Tris; $125 \mathrm{mM}$ Glycin; $3.5 \mathrm{mM}$ SDS stacking gel.... $.125 \mathrm{mM}$ Tris/HCl, pH 6.8; $4.8 \%$ acrylamide; $0.1 \%$ SDS;

0.25 mM EDTA; $0.1 \%$ TEMED; $0.1 \%$ APS

separating gel 375 Tris/ $\mathrm{HCl} \mathrm{pH} 8.8 ; 8-12 \%$ acrylamide; $0.1 \%$ SDS; 0.25 mM EDTA; $0.1 \%$ TEMED; $0.1 \%$ APS

\subsubsection{Coomassie Brilliant Blue (CBB) staining}

Visualizing of proteins with a concentration down to $300 \mathrm{ng}$, Coomassie staining (Coomassie brilliant blue R250 (Serva)) was used. Gels were incubated for about $30 \mathrm{~min}$ in a staining solution and afterwards washed several times with $\mathrm{H}_{2} \mathrm{O}$ till all not bound CBB had vanished.

CBB staining solution $0.025 \%$ Coomassie Brilliant Blue R-250; $45 \%$ Methanol; $10 \%$ acetic acid; $40 \% \mathrm{H}_{2} \mathrm{O}$ 


\subsubsection{Western blotting (TOWBIN et al., 1979)}

Western blotting was performed by using a semi dry blotting unit by manufactures instructions. Filter papers, nitrocellulose membrane und SDS gel therefore first were soaked in transfer buffer. A piece of filter paper was placed onto the anode of the chamber, followed by the membrane, the gel and another piece of filter paper. Air bubbles were rolled out of the sandwich and the cathode was placed on top of the stack. Electrophoresis was performed by using a constant voltage of $16 \mathrm{~V}$ for $1 \mathrm{~h}$. The membrane containing the transferred proteins was probed to immunostaining by first incubating for a minimum of $1 \mathrm{~h}$ with a $5 \%$ BSA blocking solution to saturate free binding sites on the membrane. After washing three times with TBS/T, the membrane was incubated with the first antibody (see table 7.1) for at least $5 \mathrm{~h}$ at $4{ }^{\circ} \mathrm{C}$ on a rocking platform. Following another three washing steps with TBS/T, the membrane was incubated with a HRPO-conjugated secondary antibody (see table 7.2) for another hour at $4{ }^{\circ} \mathrm{C}$. After washing again three times with TBS/T, proteins were visualized by using ECL detection system and exposure of the membrane to a digital imaging system (Intas).

transfer buffer $.39 \mathrm{mM}$ glycine; $48 \mathrm{mM}$ Tris; $0.0375 \%$ (w/v) SDS;

$$
0.01 \%(\mathrm{w} / \mathrm{v}) \mathrm{NaN}_{3} ; 20 \% \mathrm{MeOH}
$$

TBST. .0.5 mM Tris; $150 \mathrm{mM} \mathrm{NaCl} ; 0.1 \%$ (v/v) Tween-20

blocking solution $.5 \%$ BSA in TBST; $0.01 \% \mathrm{NaN}_{3}$

ECL detection reagent $.4 \mathrm{~mL}$ Solution A; $400 \mu \mathrm{L}$ Solution B; $1.2 \mu \mathrm{L} \mathrm{H}_{2} \mathrm{O}_{2}(30 \%)$ Solution A $.250 \mathrm{mg} / \mathrm{L}$ Luminol; $0.1 \mathrm{M}$ Tris/HCl, $\mathrm{pH} 8.6$; store at $4{ }^{\circ} \mathrm{C}$ Solution B $.11 \mathrm{mg}$ para hydroxy coumaric acid in $10 \mathrm{~mL}$ DMSO

\subsubsection{Far western}

Far western is method for visualizing direct interactions of proteins. All following steps therefore were performed at $4{ }^{\circ} \mathrm{C}$ to prevent destabilization of fusion proteins and antibodies. After transferring the proteins to the nitrocellulose membrane (as described in 7.5.3.10) it was incubated in blocking solution over night. The blocking solution was removed the next day and membrane was washed four times with PBS/T before incubating with a corresponding GST-Fusion protein for $1 \mathrm{~h}$ on a rocking platform. After washing again three times with PBS/T the membrane was incubated with anti-GST antibodies for 
$2 \mathrm{~h}$ and subsequently washed with PBS/T. Following incubation with the HRPOconjugated secondary antibody and three further washing steps, membrane was ready for probing with ECL like in 7.5.3.8 described.

blocking solution. $3 \%$ nonfat dried milk in PBST

PBST. $0.1 \%(\mathrm{v} / \mathrm{v})$ Tween-20 in PBS

\subsubsection{ELISA}

For measuring kinase assay $25 \mu \mathrm{l}$ of each reaction containing the biotinylated substrate were subjected to a Streptavidin conjugated 96-well plate. $75 \mu 1 \mathrm{ddH}_{2} 0$ were added and reaction was incubated at room temperature for about $1 \mathrm{~h}$ and $150 \mathrm{rpm}$ on a rocking platform. Plates were washed three times with PBS and first antibody (anti-pTyr; $1 \mu \mathrm{g} / \mathrm{mL}$ ) was added for another hour. Subsequent to washing three times with PBS secondary HRPO-conjugated goat anti-mouse antibody was added for $30 \mathrm{~min}$. Afterward ELISA was measured after incubating plate with ABTS for $1 \mathrm{~min}$ in an ELISA-Reader.

\section{ABTS $\ldots \ldots \ldots \ldots \ldots \ldots \ldots \ldots . . \ldots .1 \mathrm{M} \mathrm{C}_{2} \mathrm{H}_{3} \mathrm{NaO}_{2} ; 0.05 \mathrm{M} \mathrm{NaH}_{2} \mathrm{PO}_{4} ; 2 \mathrm{M}$ ABTS}

adjust $\mathrm{pH}$ to 4.2 using acidic acid 


\section{Bibliography}

Aiba Y, Oh-hora M, Kiyonaka S, Kimura Y, Hijikata A, Mori Y, Kurosaki T. (2004). Activation of RasGRP3 by phosphorylation of Thr-133 is required for B cell receptor-mediated Ras activation. Proc Natl Acad Sci U S A 101: 16612-7.

Arbuckle, M.R., M.T. McClain, M.V. Rubertone, R.H. Scofield, G.J. Dennis, J.A. James, and J.B. Harley. (2003). Development of autoantibodies before the clinical onset of systemic lupus erythematosus. N Engl J Med 349:1526-1533.

Baba TW, Giroir BP, Humphries EH. (1985). Cell lines derived from avian lymphomas exhibit two distinct phenotypes. Virology 144: 139-51.

Baba TW, Humphries EH. (1984). Differential response to avian leukosis virus infection exhibited by two chicken lines. Virology 135: 181-8.

Baba, Y., S. Hashimoto, M. Matsushita, D. Watanabe, T. Kishimoto, T. Kurosaki, and S. Tsukada. (2001). BLNK mediates Syk-dependent Btk activation. Proc Natl Acad Sci U S A 98:2582-2586.

Baeuerle, P.A., and T. Henkel. (1994). Function and activation of NF-kappa B in the immune system. Annu Rev Immunol 12:141-179.

Barbat, C., M. Trucy, M. Sorice, T. Garofalo, V. Manganelli, A. Fischer, and F. Mazerolles. (2007). p561ck, LFA-1 and PI3K but not SHP-2 interact with GM1- or GM3-enriched microdomains in a CD4-p56lck association-dependent manner. Biochem J 402:471-481.

Berridge, M.J., P. Lipp, and M.D. Bootman. (2000). The versatility and universality of calcium signalling. Nat Rev Mol Cell Biol 1:11-21.

Bolland S, Ravetch JV. (2000). Spontaneous autoimmune disease in Fc(gamma)RIIBdeficient mice results from strain-specific epistasis. Immunity 13: 277-85.

Brauweiler, A., I. Tamir, J. Dal Porto, R.J. Benschop, C.D. Helgason, R.K. Humphries, J.H. Freed, and J.C. Cambier. (2000). Differential regulation of B cell development, activation, and death by the src homology 2 domain-containing 5' inositol phosphatase (SHIP). J Exp Med 191:1545-1554.

Brdicka T, Imrich M, Angelisova P, Brdickova N, Horvath O, Spicka J, Hilgert I, Luskova P, Draber P, Novak P, Engels N, Wienands J, Simeoni L, Osterreicher J, Aguado E, Malissen M, Schraven B, Horejsi V. (2002). Non-T cell activation linker (NTAL): a transmembrane adaptor protein involved in immunoreceptor signaling. J Exp Med 196: $1617-26$. 
Brdicka, T., T.A. Kadlecek, J.P. Roose, A.W. Pastuszak, and A. Weiss. (2005). Intramolecular regulatory switch in ZAP-70: analogy with receptor tyrosine kinases. Mol Cell Biol 25:4924-4933.

Buerstedde JM, Reynaud CA, Humphries EH, Olson W, Ewert DL, Weill JC. (1990). Light chain gene conversion continues at high rate in an ALV-induced cell line. Embo J 9: 921-7.

Cambier, J.C. (1995). Antigen and Fc receptor signaling. The awesome power of the immunoreceptor tyrosine-based activation motif (ITAM). J Immunol 155:32813285.

Cambier, J.C. (1995). New nomenclature for the Reth motif (or ARH1/TAM/ARAM/YXXL). Immunol Today 16:110.

Campbell, K.S., and J.C. Cambier. (1990). B lymphocyte antigen receptors (mIg) are noncovalently associated with a disulfide linked, inducibly phosphorylated glycoprotein complex. Embo J 9:441-448.

Campbell MA, Sefton BM. (1992). Association between B-lymphocyte membrane immunoglobulin and multiple members of the Src family of protein tyrosine kinases. Mol Cell Biol 12: 2315-21.

Cantrell, D.A. (2001). Phosphoinositide 3-kinase signalling pathways. J Cell Sci 114:14391445.

Carpino, N., D. Wisniewski, A. Strife, D. Marshak, R. Kobayashi, B. Stillman, and B. Clarkson. (1997). p62(dok): a constitutively tyrosine-phosphorylated, GAPassociated protein in chronic myelogenous leukemia progenitor cells. Cell 88:197204.

Chan, O.T., L.G. Hannum, A.M. Haberman, M.P. Madaio, and M.J. Shlomchik. (1999). A novel mouse with B cells but lacking serum antibody reveals an antibodyindependent role for B cells in murine lupus. $J$ Exp Med 189:1639-1648.

Chan, V.W., C.A. Lowell, and A.L. DeFranco. (1998). Defective negative regulation of antigen receptor signaling in Lyn-deficient B lymphocytes. Curr Biol 8:545-553.

Chan, V.W., F. Meng, P. Soriano, A.L. DeFranco, and C.A. Lowell. (1997). Characterization of the B lymphocyte populations in Lyn-deficient mice and the role of Lyn in signal initiation and down-regulation. Immunity 7:69-81.

Cheng, A.M., T.M. Saxton, R. Sakai, S. Kulkarni, G. Mbamalu, W. Vogel, C.G. Tortorice, R.D. Cardiff, J.C. Cross, W.J. Muller, and T. Pawson. (1998). Mammalian Grb2 regulates multiple steps in embryonic development and malignant transformation. Cell 95:793-803. 
Chiu, C.W., M. Dalton, M. Ishiai, T. Kurosaki, and A.C. Chan. (2002). BLNK: molecular scaffolding through 'cis'-mediated organization of signaling proteins. Embo $J$ 21:6461-6472.

Chow, L.M., and A. Veillette. (1995). The Src and Csk families of tyrosine protein kinases in hemopoietic cells. Semin Immunol 7:207-226.

Clark, S.G., M.J. Stern, and H.R. Horvitz. (1992). C. elegans cell-signalling gene sem-5 encodes a protein with $\mathrm{SH} 2$ and SH3 domains. Nature 356:340-344.

Cong, F., B. Yuan, and S.P. Goff. (1999). Characterization of a novel member of the DOK family that binds and modulates Abl signaling. Mol Cell Biol 19:8314-8325.

Cooper, J.A., and B. Howell. (1993). The when and how of Src regulation. Cell 73:10511054.

Cornall, R.J., J.G. Cyster, M.L. Hibbs, A.R. Dunn, K.L. Otipoby, E.A. Clark, and C.C. Goodnow. (1998). Polygenic autoimmune traits: Lyn, CD22, and SHP-1 are limiting elements of a biochemical pathway regulating BCR signaling and selection. Immunity 8:497-508.

Crabtree, G.R., and N.A. Clipstone. (1994). Signal transmission between the plasma membrane and nucleus of T lymphocytes. Annu Rev Biochem 63:1045-1083.

Crabtree, G.R., and E.N. Olson. (2002). NFAT signaling: choreographing the social lives of cells. Cell 109 Suppl:S67-79.

Damen, J.E., L. Liu, P. Rosten, R.K. Humphries, A.B. Jefferson, P.W. Majerus, and G. Krystal. (1996). The 145-kDa protein induced to associate with Shc by multiple cytokines is an inositol tetraphosphate and phosphatidylinositol 3,4,5-triphosphate 5-phosphatase. Proc Natl Acad Sci U S A 93:1689-1693.

Davis, R.E., V.N. Ngo, G. Lenz, P. Tolar, R Davis RE, Brown KD, Siebenlist U, Staudt LM. (2001). Constitutive nuclear factor kappaB activity is required for survival of activated B cell-like diffuse large B cell lymphoma cells. J Exp Med 194: 1861-74.

.M. Young, P.B. Romesser, H. Kohlhammer, L. Lamy, H. Zhao, Y. Yang, W. Xu, A.L. Shaffer, G. Wright, W. Xiao, J. Powell, J.K. Jiang, C.J. Thomas, A. Rosenwald, G. Ott, H.K. Muller-Hermelink, R.D. Gascoyne, J.M. Connors, N.A. Johnson, L.M. Rimsza, E. Campo, E.S. Jaffe, W.H. Wilson, J. Delabie, E.B. Smeland, R.I. Fisher, R.M. Braziel, R.R. Tubbs, J.R. Cook, D.D. Weisenburger, W.C. Chan, S.K. Pierce, and L.M. Staudt. (2010). Chronic active B-cell-receptor signalling in diffuse large B-cell lymphoma. Nature 463:88-92.

DeFranco, A.L., V.W. Chan, and C.A. Lowell. (1998). Positive and negative roles of the tyrosine kinase Lyn in B cell function. Semin Immunol 10:299-307. 
Deindl, S., T.A. Kadlecek, T. Brdicka, X. Cao, A. Weiss, and J. Kuriyan. (2007). Structural basis for the inhibition of tyrosine kinase activity of ZAP-70. Cell 129:735-746.

Depoil, D., S. Fleire, B.L. Treanor, M. Weber, N.E. Harwood, K.L. Marchbank, V.L. Tybulewicz, and F.D. Batista. (2008). CD19 is essential for B cell activation by promoting $\mathrm{B}$ cell receptor-antigen microcluster formation in response to membrane-bound ligand. Nat Immunol 9:63-72.

Dolmetsch, R.E., R.S. Lewis, C.C. Goodnow, and J.I. Healy. (1997). Differential activation of transcription factors induced by $\mathrm{Ca} 2+$ response amplitude and duration. Nature 386:855-858.

Dong, S., B. Corre, E. Foulon, E. Dufour, A. Veillette, O. Acuto, and F. Michel. (2006). T cell receptor for antigen induces linker for activation of $\mathrm{T}$ cell-dependent activation of a negative signaling complex involving Dok-2, SHIP-1, and Grb-2. J Exp Med 203:2509-2518.

Doody, G.M., L.B. Justement, C.C. Delibrias, R.J. Matthews, J. Lin, M.L. Thomas, and D.T. Fearon. (1995). A role in B cell activation for CD22 and the protein tyrosine phosphatase SHP. Science 269:242-244.

Ellis, C., M. Moran, F. McCormick, and T. Pawson. (1990). Phosphorylation of GAP and GAP-associated proteins by transforming and mitogenic tyrosine kinases. Nature 343:377-381.

Engelke M, Engels N, Dittmann K, Stork B, Wienands J. (2007). Ca(2+) signaling in antigen receptor-activated B lymphocytes. Immunol Rev 218: 235-46.

Engels, N. (2005). Studien an signalleitenden Adpaterproteinen in wildtypischen und virusinfizierten Lymphocyten. Faculty of Chemistry. University of Bielefeld, Bielefeld

Engels, N., M. Engelke, and J. Wienands. (2008). Conformational plasticity and navigation of signaling proteins in antigen-activated B lymphocytes. Adv Immunol 97:251281.

Engels, N., L.M. Konig, C. Heemann, J. Lutz, T. Tsubata, S. Griep, V. Schrader, and J. Wienands. (2009). Recruitment of the cytoplasmic adaptor Grb2 to surface IgG and IgE provides antigen receptor-intrinsic costimulation to class-switched B cells. Nat Immunol 10:1018-1025.

Engels, N., B. Wollscheid, and J. Wienands. (2001). Association of SLP-65/BLNK with the B cell antigen receptor through a non-ITAM tyrosine of Ig-alpha. Eur $J$ Immunol 31:2126-2134. 
Enyedy, E.J., J.P. Mitchell, M.P. Nambiar, and G.C. Tsokos. (2001). Defective FcgammaRIIb1 signaling contributes to enhanced calcium response in B cells from patients with systemic lupus erythematosus. Clin Immunol 101:130-135.

Fanger, C.M., M. Hoth, G.R. Crabtree, and R.S. Lewis. (1995). Characterization of T cell mutants with defects in capacitative calcium entry: genetic evidence for the physiological roles of CRAC channels. J Cell Biol 131:655-667.

Fawcett, V.C., and U. Lorenz. (2005). Localization of Src homology 2 domain-containing phosphatase 1 (SHP-1) to lipid rafts in T lymphocytes: functional implications and a role for the SHP-1 carboxyl terminus. J Immunol 174:2849-2859.

Flaswinkel, H., and M. Reth. (1994). Dual role of the tyrosine activation motif of the Igalpha protein during signal transduction via the B cell antigen receptor. Embo $J$ 13:83-89.

Fluckiger, A.C., Z. Li, R.M. Kato, M.I. Wahl, H.D. Ochs, R. Longnecker, J.P. Kinet, O.N. Witte, A.M. Scharenberg, and D.J. Rawlings. (1998). Btk/Tec kinases regulate sustained increases in intracellular $\mathrm{Ca} 2+$ following B-cell receptor activation. Embo $J$ 17:1973-1985.

Forman-Kay, J.D., and T. Pawson. (1999). Diversity in protein recognition by PTB domains. Curr Opin Struct Biol 9:690-695.

Frantz, B., E.C. Nordby, G. Bren, N. Steffan, C.V. Paya, R.L. Kincaid, M.J. Tocci, S.J. O'Keefe, and E.A. O'Neill. (1994). Calcineurin acts in synergy with PMA to inactivate I kappa B/MAD3, an inhibitor of NF-kappa B. Embo J 13:861-870.

Fu, C., and A.C. Chan. (1997). Identification of two tyrosine phosphoproteins, pp70 and pp68, which interact with phospholipase Cgamma, Grb2, and Vav after B cell antigen receptor activation. J Biol Chem 272:27362-27368.

Fu, C., C.W. Turck, T. Kurosaki, and A.C. Chan. (1998). BLNK: a central linker protein in B cell activation. Immunity 9:93-103.

Furlong, M.T., A.M. Mahrenholz, K.H. Kim, C.L. Ashendel, M.L. Harrison, and R.L. Geahlen. (1997). Identification of the major sites of autophosphorylation of the murine protein-tyrosine kinase Syk. Biochim Biophys Acta 1355:177-190.

Fusaki, N., S. Tomita, Y. Wu, N. Okamoto, R. Goitsuka, D. Kitamura, and N. Hozumi. (2000). BLNK is associated with the CD72/SHP-1/Grb2 complex in the WEHI231 cell line after membrane IgM cross-linking. Eur J Immunol 30:1326-1330.

Gellert, M. (2002). V(D)J recombination: RAG proteins, repair factors, and regulation. Aпnи Rev Biochem 71:101-132. 
Goitsuka, R., Y. Fujimura, H. Mamada, A. Umeda, T. Morimura, K. Uetsuka, K. Doi, S. Tsuji, and D. Kitamura. (1998). BASH, a novel signaling molecule preferentially expressed in B cells of the bursa of Fabricius. J Immunol 161:5804-5808.

Goldbeck,I. (2007). Studien zur subzellulären Navigation von Signalmolekülen der Ca2+Antwort in aktivierten B-Lymphocyten. Faculty of Chemistry. University of Bielefeld, Bielefeld

Goodnow, C.C., R. Glynne, D. Mack, B. Weintraub, J. Rathmell, J.I. Healy, S. Chaudhry, L. Miosge, A. Loy, and L. Wilson. (1999). Mechanisms of self-tolerance and autoimmunity: from whole-animal phenotypes to molecular pathways. Cold Spring Harb Symp Quant Biol 64:313-322.

Grabbe, A., and J. Wienands. (2006). Human SLP-65 isoforms contribute differently to activation and apoptosis of B lymphocytes. Blood 108:3761-3768.

Grawunder, U., R.B. West, and M.R. Lieber. (1998). Antigen receptor gene rearrangement. Curr Opin Immunol 10:172-180.

Harmer, S.L., and A.L. DeFranco. (1999). The src homology domain 2-containing inositol phosphatase SHIP forms a ternary complex with Shc and Grb2 in antigen receptorstimulated B lymphocytes. J Biol Chem 274:12183-12191.

Hashimoto, A., K. Takeda, M. Inaba, M. Sekimata, T. Kaisho, S. Ikehara, Y. Homma, S. Akira, and T. Kurosaki. (2000). Cutting edge: essential role of phospholipase Cgamma 2 in B cell development and function. J Immunol 165:1738-1742.

Helgason, C.D., J.E. Damen, P. Rosten, R. Grewal, P. Sorensen, S.M. Chappel, A. Borowski, F. Jirik, G. Krystal, and R.K. Humphries. (1998). Targeted disruption of SHIP leads to hemopoietic perturbations, lung pathology, and a shortened life span. Genes Dev 12:1610-1620.

Helgason, C.D., C.P. Kalberer, J.E. Damen, S.M. Chappel, N. Pineault, G. Krystal, and R.K. Humphries. (2000). A dual role for Src homology 2 domain-containing inositol-5-phosphatase (SHIP) in immunity: aberrant development and enhanced function of b lymphocytes in ship -/- mice. J Exp Med 191:781-794.

Herzog, S., M. Reth, and H. Jumaa. (2009). Regulation of B-cell proliferation and differentiation by pre-B-cell receptor signalling. Nat Rev Immunol 9:195-205.

Hibbs, M.L., D.M. Tarlinton, J. Armes, D. Grail, G. Hodgson, R. Maglitto, S.A. Stacker, and A.R. Dunn. (1995). Multiple defects in the immune system of Lyn-deficient mice, culminating in autoimmune disease. Cell 83:301-311. 
Hombach, J., T. Tsubata, L. Leclercq, H. Stappert, and M. Reth. (1990). Molecular components of the B-cell antigen receptor complex of the IgM class. Nature 343:760-762.

Humphries, L.A., C. Dangelmaier, K. Sommer, K. Kipp, R.M. Kato, N. Griffith, I. Bakman, C.W. Turk, J.L. Daniel, and D.J. Rawlings. (2004). Tec kinases mediate sustained calcium influx via site-specific tyrosine phosphorylation of the phospholipase Cgamma Src homology 2-Src homology 3 linker. J Biol Chem 279:37651-37661.

Inabe K, Ishiai M, Scharenberg AM, Freshney N, Downward J, Kurosaki T. (2002). Vav3 modulates $\mathrm{B}$ cell receptor responses by regulating phosphoinositide 3-kinase activation. J Exp Med 195: 189-200.

Ishiai, M., H. Sugawara, M. Kurosaki, and T. Kurosaki. (1999). Cutting edge: association of phospholipase C-gamma 2 Src homology 2 domains with BLNK is critical for B cell antigen receptor signaling. J Immunol 163:1746-1749.

Jaffe, E.S., N.L. Harris, H. Stein, and P.G. Isaacson. (2008). Classification of lymphoid neoplasms: the microscope as a tool for disease discovery. Blood 112:4384-4399.

Jang, I.K., J. Zhang, Y.J. Chiang, H.K. Kole, D.G. Cronshaw, Y. Zou, and H. Gu. (2010). Grb2 functions at the top of the T-cell antigen receptor-induced tyrosine kinase cascade to control thymic selection. Proc Natl Acad Sci U S A 107:10620-10625.

Jang, I.K., J. Zhang, and H. Gu. (2009). Grb2, a simple adapter with complex roles in lymphocyte development, function, and signaling. Immunol Rev 232:150-159.

Johmura, S., M. Oh-hora, K. Inabe, Y. Nishikawa, K. Hayashi, E. Vigorito, D. Kitamura, M. Turner, K. Shingu, M. Hikida, and T. Kurosaki. (2003). Regulation of Vav localization in membrane rafts by adaptor molecules Grb2 and BLNK. Immunity 18:777-787.

Jones, N., and D.J. Dumont. (1998). The Tek/Tie2 receptor signals through a novel Dokrelated docking protein, Dok-R. Oncogene 17:1097-1108.

Karasuyama, H., A. Rolink, and F. Melchers. (1996). Surrogate light chain in B cell development. Adv Immunol 63:1-41.

Kessels, H.W., A.C. Ward, and T.N. Schumacher. (2002). Specificity and affinity motifs for Grb2 SH2-ligand interactions. Proc Natl Acad Sci U S A 99:8524-8529.

Khan WN, Alt FW, Gerstein RM, Malynn BA, Larsson I, Rathbun G, Davidson L, Muller S, Kantor AB, Herzenberg LA, et al. (1995). Defective B cell development and function in Btk-deficient mice. Immunity 3: 283-99. 
Kim S, Humphries EH, Tjoelker L, Carlson L, Thompson CB. (1990). Ongoing diversification of the rearranged immunoglobulin light-chain gene in a bursal lymphoma cell line. Mol Cell Biol 10: 3224-31.

Kim, Y.J., F. Sekiya, B. Poulin, Y.S. Bae, and S.G. Rhee. (2004). Mechanism of B-cell receptor-induced phosphorylation and activation of phospholipase C-gamma2. Mol Cell Biol 24:9986-9999.

Kimura, T., H. Sakamoto, E. Appella, and R.P. Siraganian. (1996). Conformational changes induced in the protein tyrosine kinase p72syk by tyrosine phosphorylation or by binding of phosphorylated immunoreceptor tyrosine-based activation motif peptides. Mol Cell Biol 16:1471-1478.

Kohler, F., B. Storch, Y. Kulathu, S. Herzog, S. Kuppig, M. Reth, and H. Jumaa. (2005). A leucine zipper in the $\mathrm{N}$ terminus confers membrane association to SLP-65. Nat Immunol 6:204-210.

Kurosaki, T. (1999). Genetic analysis of B cell antigen receptor signaling. Annu Rev Immunol 17:555-592.

Kurosaki, T. (2002). Regulation of B-cell signal transduction by adaptor proteins. Nat Rev Immunol 2:354-363.

Kurosaki, T., S.A. Johnson, L. Pao, K. Sada, H. Yamamura, and J.C. Cambier. (1995). Role of the Syk autophosphorylation site and $\mathrm{SH} 2$ domains in B cell antigen receptor signaling. J Exp Med 182:1815-1823.

Kurosaki, T., and M. Kurosaki. (1997). Transphosphorylation of Bruton's tyrosine kinase on tyrosine 551 is critical for B cell antigen receptor function. $J$ Biol Chem 272:15595-15598.

Kurosaki, T., M. Takata, Y. Yamanashi, T. Inazu, T. Taniguchi, T. Yamamoto, and H. Yamamura. (1994). Syk activation by the Src-family tyrosine kinase in the B cell receptor signaling. J Exp Med 179:1725-1729.

Kurosaki, T., and S. Tsukada. (2000). BLNK: connecting Syk and Btk to calcium signals. Immunity 12:1-5.

Laemmli, U.K. (1970). Cleavage of structural proteins during the assembly of the head of bacteriophage T4. Nature 227:680-685.

Lam, K.P., R. Kuhn, and K. Rajewsky. (1997). In vivo ablation of surface immunoglobulin on mature $\mathrm{B}$ cells by inducible gene targeting results in rapid cell death. Cell 90:1073-1083. 
Law, C.L., S.P. Sidorenko, K.A. Chandran, Z. Zhao, S.H. Shen, E.H. Fischer, and E.A. Clark. (1996). CD22 associates with protein tyrosine phosphatase 1C, Syk, and phospholipase C-gamma(1) upon B cell activation. J Exp Med 183:547-560.

Lederman HM, Winkelstein JA. (1985). X-linked agammaglobulinemia: an analysis of 96 patients. Medicine (Baltimore) 64: 145-56.

Lemay, S., D. Davidson, S. Latour, and A. Veillette. (2000). Dok-3, a novel adapter molecule involved in the negative regulation of immunoreceptor signaling. Mol Cell Biol 20:2743-2754.

Lemmon, M.A. (2004). Pleckstrin homology domains: not just for phosphoinositides. Biochem Soc Trans 32:707-711.

Lemmon, M.A., and K.M. Ferguson. (1998). Pleckstrin homology domains. Curr Top Microbiol Immunol 228:39-74.

Lenz G, Davis RE, Ngo VN, Lam L, George TC, Wright GW, Dave SS, Zhao H, Xu W, Rosenwald A, Ott G, Muller-Hermelink HK, Gascoyne RD, Connors JM, Rimsza LM, Campo E, Jaffe ES, Delabie J, Smeland EB, Fisher RI, Chan WC, Staudt LM. (2008). Oncogenic CARD11 mutations in human diffuse large B cell lymphoma. Science 319: 1676-9.

Li N, Batzer A, Daly R, Yajnik V, Skolnik E, Chardin P, Bar-Sagi D, Margolis B, Schlessinger J. (1993). Guanine-nucleotide-releasing factor hSos1 binds to Grb2 and links receptor tyrosine kinases to Ras signalling. Nature 363: 85-8.

Lindquist, J.A., L. Simeoni, and B. Schraven. (2003). Transmembrane adapters: attractants for cytoplasmic effectors. Immunol Rev 191:165-182.

Liossis, S.N., B. Kovacs, G. Dennis, G.M. Kammer, and G.C. Tsokos. (1996). B cells from patients with systemic lupus erythematosus display abnormal antigen receptormediated early signal transduction events. J Clin Invest 98:2549-2557.

Liossis, S.N., E.E. Solomou, M.A. Dimopoulos, P. Panayiotidis, M.M. Mavrikakis, and P.P. Sfikakis. (2001). B-cell kinase lyn deficiency in patients with systemic lupus erythematosus. J Investig Med 49:157-165.

Liou, J., M.L. Kim, W.D. Heo, J.T. Jones, J.W. Myers, J.E. Ferrell, Jr., and T. Meyer. (2005). STIM is a Ca2+ sensor essential for $\mathrm{Ca} 2+$-store-depletion-triggered $\mathrm{Ca} 2+$ influx. Curr Biol 15:1235-1241.

Liu, Q., A.J. Oliveira-Dos-Santos, S. Mariathasan, D. Bouchard, J. Jones, R. Sarao, I. Kozieradzki, P.S. Ohashi, J.M. Penninger, and D.J. Dumont. (1998). The inositol polyphosphate 5-phosphatase ship is a crucial negative regulator of B cell antigen receptor signaling. $J$ Exp Med 188:1333-1342. 
Loder F, Mutschler B, Ray RJ, Paige CJ, Sideras P, Torres R, Lamers MC, Carsetti R. (1999). B cell development in the spleen takes place in discrete steps and is determined by the quality of B cell receptor-derived signals. J Exp Med 190: 75-89.

Loh, M.L., S. Vattikuti, S. Schubbert, M.G. Reynolds, E. Carlson, K.H. Lieuw, J.W. Cheng, C.M. Lee, D. Stokoe, J.M. Bonifas, N.P. Curtiss, J. Gotlib, S. Meshinchi, M.M. Le Beau, P.D. Emanuel, and K.M. Shannon. (2004). Mutations in PTPN11 implicate the SHP-2 phosphatase in leukemogenesis. Blood 103:2325-2331.

Lowenstein, E.J., R.J. Daly, A.G. Batzer, W. Li, B. Margolis, R. Lammers, A. Ullrich, E.Y. Skolnik, D. Bar-Sagi, and J. Schlessinger. (1992). The SH2 and SH3 domaincontaining protein GRB2 links receptor tyrosine kinases to ras signaling. Cell 70:431-442.

Mackay, M., A. Stanevsky, T. Wang, C. Aranow, M. Li, S. Koenig, J.V. Ravetch, and B. Diamond. (2006). Selective dysregulation of the FcgammaIIB receptor on memory B cells in SLE. J Exp Med 203:2157-2164.

Maeda A, Kurosaki M, Ono M, Takai T, Kurosaki T. (1998). Requirement of SH2containing protein tyrosine phosphatases SHP-1 and SHP-2 for paired immunoglobulin-like receptor B (PIR-B)-mediated inhibitory signal. J Exp Med 187: $1355-60$.

Mahajan, S., J. Fargnoli, A.L. Burkhardt, S.A. Kut, S.J. Saouaf, and J.B. Bolen. (1995). Src family protein tyrosine kinases induce autoactivation of Bruton's tyrosine kinase. Mol Cell Biol 15:5304-5311.

Manjarrez-Orduno, N., T.D. Quach, and I. Sanz. (2009). B cells and immunological tolerance. J Invest Dermatol 129:278-288.

Martensson, I.L., R.A. Keenan, and S. Licence. (2007). The pre-B-cell receptor. Curr Opin Immunol 19:137-142.

Matsumoto R, Wang D, Blonska M, Li H, Kobayashi M, Pappu B, Chen Y, Wang D, Lin $X$. (2005). Phosphorylation of CARMA1 plays a critical role in T Cell receptormediated NF-kappaB activation. Immunity 23: 575-85.

Meyer, D., A. Liu, and B. Margolis. (1999). Interaction of c-Jun amino-terminal kinase interacting protein-1 with p190 rhoGEF and its localization in differentiated neurons. J Biol Chem 274:35113-35118.

Minegishi Y, Rohrer J, Conley ME. (1999). Recent progress in the diagnosis and treatment of patients with defects in early B-cell development. Curr Opin Pediatr 11: 528-32. 
Monroe, J.G., G. Bannish, E.M. Fuentes-Panana, L.B. King, P.C. Sandel, J. Chung, and R. Sater. (2003). Positive and negative selection during B lymphocyte development. Immunol Res 27:427-442.

Morita S, Kojima T, Kitamura T. (2000). Plat-E: an efficient and stable system for transient packaging of retroviruses. Gene Ther 7: 1063-6.

Mullis K, Faloona F, Scharf S, Saiki R, Horn G, Erlich H. (1986). Specific enzymatic amplification of DNA in vitro: the polymerase chain reaction. Cold Spring Harb Symp Quant Biol 51 Pt 1: 263-73.

Mullis KB, Faloona FA. (1987). Specific synthesis of DNA in vitro via a polymerasecatalyzed chain reaction. Methods Enzymol 155: 335-50.

Negulescu, P.A., N. Shastri, and M.D. Cahalan. (1994). Intracellular calcium dependence of gene expression in single T lymphocytes. Proc Natl Acad Sci U S A 91:28732877.

Nelms K, Snow AL, Hu-Li J, Paul WE. (1998). FRIP, a hematopoietic cell-specific rasGAP-interacting protein phosphorylated in response to cytokine stimulation. Immunity 9: 13-24.

Neuberger, M.S., K.J. Patel, P. Dariavach, K. Nelms, C.J. Peaker, and G.T. Williams. (1993). The mouse B-cell antigen receptor: definition and assembly of the core receptor of the five immunoglobulin isotypes. Immunol Rev 132:147-161.

Neumann, K., T. Oellerich, H. Urlaub, and J. Wienands. (2009). The B-lymphoid Grb2 interaction code. Immunol Rev 232:135-149.

Neumann, K., (2008). On adaptor proteins shaping Ca2+ signals inactivated B lymphocytes. Faculty of Chemistry. University of Bielefeld, Bielefeld

Newton, A.C. (1997). Regulation of protein kinase C. Curr Opin Cell Biol 9:161-167.

Ng, C.H., S. Xu, and K.P. Lam. (2007). Dok-3 plays a non-redundant role in negative regulation of B cell activation. Blood 110:259-66.

Niki, M., A. Di Cristofano, M. Zhao, H. Honda, H. Hirai, L. Van Aelst, C. Cordon-Cardo, and P.P. Pandolfi. (2004). Role of Dok-1 and Dok-2 in leukemia suppression. J Exp Med 200:1689-1695.

Nishida, M., K. Nagata, Y. Hachimori, M. Horiuchi, K. Ogura, V. Mandiyan, J. Schlessinger, and F. Inagaki. (2001). Novel recognition mode between Vav and Grb2 SH3 domains. Embo J 20:2995-3007. 
Nishizumi, H., I. Taniuchi, Y. Yamanashi, D. Kitamura, D. Ilic, S. Mori, T. Watanabe, and T. Yamamoto. (1995). Impaired proliferation of peripheral B cells and indication of autoimmune disease in lyn-deficient mice. Immunity 3:549-560.

Noguchi, T., T. Matozaki, K. Horita, Y. Fujioka, and M. Kasuga. (1994). Role of SHPTP2, a protein-tyrosine phosphatase with Src homology 2 domains, in insulinstimulated Ras activation. Mol Cell Biol 14:6674-6682.

Oancea, E., and T. Meyer. (1998). Protein kinase C as a molecular machine for decoding calcium and diacylglycerol signals. Cell 95:307-318.

Ochs HD, Smith CI. (1996). X-linked agammaglobulinemia. A clinical and molecular analysis. Medicine (Baltimore) 75: 287-99.

Oh-hora M, Johmura S, Hashimoto A, Hikida M, Kurosaki T. (2003). Requirement for Ras guanine nucleotide releasing protein 3 in coupling phospholipase C-gamma2 to Ras in B cell receptor signaling. J Exp Med 198: 1841-51.

Olivier, J.P., T. Raabe, M. Henkemeyer, B. Dickson, G. Mbamalu, B. Margolis, J. Schlessinger, E. Hafen, and T. Pawson. (1993). A Drosophila SH2-SH3 adaptor protein implicated in coupling the sevenless tyrosine kinase to an activator of Ras guanine nucleotide exchange, Sos. Cell 73:179-191.

Ono M, Okada H, Bolland S, Yanagi S, Kurosaki T, Ravetch JV. (1997). Deletion of SHIP or SHP-1 reveals two distinct pathways for inhibitory signaling. Cell 90: 293-301.

Ott, V.L., I. Tamir, M. Niki, P.P. Pandolfi, and J.C. Cambier. (2002). Downstream of kinase, p62(dok), is a mediator of Fc gamma IIB inhibition of Fc epsilon RI signaling. J Immunol 168:4430-4439.

Pani, G., M. Kozlowski, J.C. Cambier, G.B. Mills, and K.A. Siminovitch. (1995). Identification of the tyrosine phosphatase PTP1C as a B cell antigen receptorassociated protein involved in the regulation of B cell signaling. $J$ Exp Med 181:2077-2084.

Pao, L.I., S.J. Famiglietti, and J.C. Cambier. (1998). Asymmetrical phosphorylation and function of immunoreceptor tyrosine-based activation motif tyrosines in B cell antigen receptor signal transduction. J Immunol 160:3305-3314.

Parekh, A.B., and R. Penner. (1997). Store depletion and calcium influx. Physiol Rev 77:901-930.

Parekh, A.B., and J.W. Putney, Jr. (2005). Store-operated calcium channels. Physiol Rev 85:757-810. 
Parsons, S.A., D.P. Millay, B.J. Wilkins, O.F. Bueno, G.L. Tsika, J.R. Neilson, C.M. Liberatore, K.E. Yutzey, G.R. Crabtree, R.W. Tsika, and J.D. Molkentin. (2004). Genetic loss of calcineurin blocks mechanical overload-induced skeletal muscle fiber type switching but not hypertrophy. J Biol Chem 279:26192-26200.

Patterson RL, Boehning D, Snyder SH. (2004). Inositol 1,4,5-trisphosphate receptors as signal integrators. Annu Rev Biochem 73: 437-65.

Pleiman, C.M., C. Abrams, L.T. Gauen, W. Bedzyk, J. Jongstra, A.S. Shaw, and J.C. Cambier. (1994). Distinct p53/56lyn and p59fyn domains associate with nonphosphorylated and phosphorylated Ig-alpha. Proc Natl Acad Sci U S A 91:4268-4272.

Prakriya, M., S. Feske, Y. Gwack, S. Srikanth, A. Rao, and P.G. Hogan. (2006). Orai1 is an essential pore subunit of the CRAC channel. Nature 443:230-233.

Pugh-Bernard, A.E., and J.C. Cambier. (2006). B cell receptor signaling in human systemic lupus erythematosus. Curr Opin Rheumatol 18:451-455.

Ramos-Morales, F., F. Romero, F. Schweighoffer, G. Bismuth, J. Camonis, M. Tortolero, and S. Fischer. (1995). The proline-rich region of Vav binds to Grb2 and Grb3-3. Oncogene 11:1665-1669.

Rao, A. (1994). NF-ATp: a transcription factor required for the co-ordinate induction of several cytokine genes. Immunol Today 15:274-281.

Rawlings DJ. (1999). Bruton's tyrosine kinase controls a sustained calcium signal essential for B lineage development and function. Clin Immunol 91: 243-53.

Rawlings DJ, Saffran DC, Tsukada S, Largaespada DA, Grimaldi JC, Cohen L, Mohr RN, Bazan JF, Howard M, Copeland NG, et al. (1993). Mutation of unique region of Bruton's tyrosine kinase in immunodeficient XID mice. Science 261: 358-61.

Rawlings, D.J., A.M. Scharenberg, H. Park, M.I. Wahl, S. Lin, R.M. Kato, A.C. Fluckiger, O.N. Witte, and J.P. Kinet. (1996). Activation of BTK by a phosphorylation mechanism initiated by SRC family kinases. Science 271:822-825.

Reth, M. (1989). Antigen receptor tail clue. Nature 338:383-384.

Reth, M. (1992). Antigen receptors on B lymphocytes. Annu Rev Immunol 10:97-121.

Reth, M., J. Hombach, J. Wienands, K.S. Campbell, N. Chien, L.B. Justement, and J.C. Cambier. (1991). The B-cell antigen receptor complex. Immunol Today 12:196201. 
Robson, J.D., D. Davidson, and A. Veillette. (2004). Inhibition of the Jun N-terminal protein kinase pathway by SHIP-1, a lipid phosphatase that interacts with the adaptor molecule Dok-3. Mol Cell Biol 24:2332-2343.

Roos, J., P.J. DiGregorio, A.V. Yeromin, K. Ohlsen, M. Lioudyno, S. Zhang, O. Safrina, J.A. Kozak, S.L. Wagner, M.D. Cahalan, G. Velicelebi, and K.A. Stauderman. (2005). STIM1, an essential and conserved component of store-operated $\mathrm{Ca} 2+$ channel function. J Cell Biol 169:435-445.

Rowley, R.B., A.L. Burkhardt, H.G. Chao, G.R. Matsueda, and J.B. Bolen. (1995). Syk protein-tyrosine kinase is regulated by tyrosine-phosphorylated Ig alpha/Ig beta immunoreceptor tyrosine activation motif binding and autophosphorylation. $J$ Biol Chem 270:11590-11594.

Sada, K., T. Takano, S. Yanagi, and H. Yamamura. (2001). Structure and function of Syk protein-tyrosine kinase. J Biochem (Tokyo) 130:177-186.

Saijo K, Mecklenbrauker I, Santana A, Leitger M, Schmedt C, Tarakhovsky A. (2002). Protein kinase $\mathrm{C}$ beta controls nuclear factor kappaB activation in $\mathrm{B}$ cells through selective regulation of the IkappaB kinase alpha. J Exp Med 195: 1647-52.

Saiki RK, Scharf S, Faloona F, Mullis KB, Horn GT, Erlich HA, Arnheim N. (1985). Enzymatic amplification of beta-globin genomic sequences and restriction site analysis for diagnosis of sickle cell anemia. Science 230: 1350-4.

Salmond, R.J., G. Huyer, A. Kotsoni, L. Clements, and D.R. Alexander. (2005). The src homology 2 domain-containing tyrosine phosphatase 2 regulates primary $\mathrm{T}$ dependent immune responses and Th cell differentiation. J Immunol 175:64986508.

Samelson, L.E. (2002). Signal transduction mediated by the T cell antigen receptor: the role of adapter proteins. Annu Rev Immunol 20:371-394.

Sanchez M, Misulovin Z, Burkhardt AL, Mahajan S, Costa T, Franke R, Bolen JB, Nussenzweig M. (1993). Signal transduction by immunoglobulin is mediated through Ig alpha and Ig beta. J Exp Med 178: 1049-55.

Sanger, F., S. Nicklen, and A.R. Coulson. (1992). DNA sequencing with chain-terminating inhibitors. 1977. Biotechnology 24:104-108.

Saxton, T.M., M Henkemeyer, S. Gasca, R. Shen, DJ. Rossi, F. Shalaby, GS. Feng, and T. Pawson. (1997). Abnormal mesoderm patterning in mouse embryos mutant for the SH2 tyrosine phosphatase Shp-2. EMBO J 16:2352-64. 
Saxton, T.M., B.G. Ciruna, D. Holmyard, S. Kulkarni, K. Harpal, J. Rossant, and T. Pawson. (2000). The SH2 tyrosine phosphatase shp2 is required for mammalian limb development. Nat Genet 24:420-423.

Saxton, T.M., and T. Pawson. (1999). Morphogenetic movements at gastrulation require the SH2 tyrosine phosphatase Shp2. Proc Natl Acad Sci U S A 96:3790-3795.

Schamel, W.W., and M. Reth. (2000). Monomeric and oligomeric complexes of the B cell antigen receptor. Immunity 13:5-14.

Schlessinger, J., and M.A. Lemmon. (2003). SH2 and PTB domains in tyrosine kinase signaling. Sci STKE (2003):RE12.

Shibasaki, F., E.R. Price, D. Milan, and F. McKeon. (1996). Role of kinases and the phosphatase calcineurin in the nuclear shuttling of transcription factor NF-AT4. Nature 382:370-373.

Shinohara H, Yasuda T, Aiba Y, Sanjo H, Hamadate M, Watarai H, Sakurai H, Kurosaki T. (2005). PKC beta regulates BCR-mediated IKK activation by facilitating the interaction between TAK1 and CARMA1. J Exp Med 202: 1423-31.

Sideras P, Muller S, Shiels H, Jin H, Khan WN, Nilsson L, Parkinson E, Thomas JD, Branden L, Larsson I, et al. (1994). Genomic organization of mouse and human Bruton's agammaglobulinemia tyrosine kinase (Btk) loci. J Immunol 153: 5607-17.

Smith, K.G., D.M. Tarlinton, G.M. Doody, M.L. Hibbs, and D.T. Fearon. (1998). Inhibition of the B cell by CD22: a requirement for Lyn. $J$ Exp Med 187:807-811.

Sommer K, Guo B, Pomerantz JL, Bandaranayake AD, Moreno-Garcia ME, Ovechkina YL, Rawlings DJ. (2005). Phosphorylation of the CARMA1 linker controls NFkappaB activation. Immunity 23: 561-74.

Sonoda E, Morrison C, Yamashita YM, Takata M, Takeda S. (2001). Reverse genetic studies of homologous DNA recombination using the chicken B-lymphocyte line, DT40. Philos Trans R Soc Lond B Biol Sci 356: 111-7.

Stork, B., M. Engelke, J. Frey, V. Horejsi, A. Hamm-Baarke, B. Schraven, T. Kurosaki, and J. Wienands. (2004). Grb2 and the non-T cell activation linker NTAL constitute a $\mathrm{Ca}(2+)$-regulating signal circuit in B lymphocytes. Immunity 21:681691.

Stork, B., K. Neumann, I. Goldbeck, S. Alers, T. Kahne, M. Naumann, M. Engelke, and J. Wienands. (2007). Subcellular localization of Grb2 by the adaptor protein Dok-3 restricts the intensity of Ca2+ signaling in B cells. Embo J 26:1140-1149. 
Suda, T., F. Arai, and A. Hirao. (2005). Hematopoietic stem cells and their niche. Trends Immunol 26:426-433.

Taddie, J.A., T.R. Hurley, B.S. Hardwick, and B.M. Sefton. (1994). Activation of B- and T-cells by the cytoplasmic domains of the B-cell antigen receptor proteins Ig-alpha and Ig-beta. J Biol Chem 269:13529-13535.

Takata, M., and T. Kurosaki. (1996). A role for Bruton's tyrosine kinase in B cell antigen receptor-mediated activation of phospholipase C-gamma 2. J Exp Med 184:31-40.

Takata, M., H. Sabe, A. Hata, T. Inazu, Y. Homma, T. Nukada, H. Yamamura, and T. Kurosaki. (1994). Tyrosine kinases Lyn and Syk regulate B cell receptor-coupled $\mathrm{Ca} 2+$ mobilization through distinct pathways. Embo J 13:1341-1349.

Tamir, I., J.C. Stolpa, C.D. Helgason, K. Nakamura, P. Bruhns, M. Daeron, and J.C. Cambier. (2000). The RasGAP-binding protein p62dok is a mediator of inhibitory FcgammaRIIB signals in B cells. Immunity 12:347-358.

Tang, T.L., R.M. Freeman, Jr., A.M. O'Reilly, B.G. Neel, and S.Y. Sokol. (1995). The SH2-containing protein-tyrosine phosphatase SH-PTP2 is required upstream of MAP kinase for early Xenopus development. Cell 80:473-483.

Tartaglia, M., P.D. Cotter, G. Zampino, B.D. Gelb, and K.A. Rauen. (2003). Exclusion of PTPN11 mutations in Costello syndrome: further evidence for distinct genetic etiologies for Noonan, cardio-facio-cutaneous and Costello syndromes. Clin Genet 63:423-426.

Tartaglia, M., E.L. Mehler, R. Goldberg, G. Zampino, H.G. Brunner, H. Kremer, I. van der Burgt, A.H. Crosby, A. Ion, S. Jeffery, K. Kalidas, M.A. Patton, R.S. Kucherlapati, and B.D. Gelb. (2001). Mutations in PTPN11, encoding the protein tyrosine phosphatase SHP-2, cause Noonan syndrome. Nat Genet 29:465-468.

Timmerman, L.A., N.A. Clipstone, S.N. Ho, J.P. Northrop, and G.R. Crabtree. (1996). Rapid shuttling of NF-AT in discrimination of $\mathrm{Ca} 2+$ signals and immunosuppression. Nature 383:837-840.

Tognon CE, Kirk HE, Passmore LA, Whitehead IP, Der CJ, Kay RJ. (1998). Regulation of RasGRP via a phorbol ester-responsive C1 domain. Mol Cell Biol 18: 6995-7008.

Towbin, H., T. Staehelin, and J. Gordon. (1979). Electrophoretic transfer of proteins from polyacrylamide gels to nitrocellulose sheets: procedure and some applications. Proc Natl Acad Sci U S A 76:4350-4354.

Tsang, E., A.M. Giannetti, D. Shaw, M. Dinh, J.K. Tse, S. Gandhi, H. Ho, S. Wang, E. Papp, and J.M. Bradshaw. (2008). Molecular mechanism of the Syk activation switch. J Biol Chem 283:32650-32659. 
Tsukada S, Rawlings DJ, Witte ON. (1994). Role of Bruton's tyrosine kinase in immunodeficiency. Curr Opin Immunol 6: 623-30.

Tuscano, J.M., P. Engel, T.F. Tedder, A. Agarwal, and J.H. Kehrl. (1996). Involvement of p72syk kinase, p53/56lyn kinase and phosphatidyl inositol-3 kinase in signal transduction via the human B lymphocyte antigen CD22. Eur J Immunol 26:12461252.

Veillette, A., S. Latour, and D. Davidson. (2002). Negative regulation of immunoreceptor signaling. Annu Rev Immunol 20:669-707.

Vihinen, M., P.T. Mattsson, and C.I. Smith. (1997). BTK, the tyrosine kinase affected in X-linked agammaglobulinemia. Front Biosci 2:d27-42.

Wang, H., J. Feng, C.F. Qi, Z. Li, H.C. Morse, 3rd, and S.H. Clarke. (2007). Transitional B cells lose their ability to receptor edit but retain their potential for positive and negative selection. J Immunol 179:7544-7552.

Weber, M., B. Treanor, D. Depoil, H. Shinohara, N.E. Harwood, M. Hikida, T. Kurosaki, and F.D. Batista. (2008). Phospholipase C-gamma2 and Vav cooperate within signaling microclusters to propagate B cell spreading in response to membranebound antigen. $J$ Exp Med 205:853-868.

Weissman, I.L. (2000). Stem cells: units of development, units of regeneration, and units in evolution. Cell 100:157-168.

Wienands, J. (2000). The B-cell antigen receptor: formation of signaling complexes and the function of adaptor proteins. Curr Top Microbiol Immunol 245:53-76.

Wienands, J. (2000). Signal transduction elements of the B cell antigen receptor and their role in immunodeficiencies. Immunobiology 202:120-133.

Wienands J, Freuler F, Baumann G. (1995). Tyrosine-phosphorylated forms of Ig beta, CD22, TCR zeta and HOSS are major ligands for tandem SH2 domains of Syk. Int Immunol 7: 1701-8

Wienands, J., J. Schweikert, B. Wollscheid, H. Jumaa, P.J. Nielsen, and M. Reth. (1998). SLP-65: a new signaling component in B lymphocytes which requires expression of the antigen receptor for phosphorylation. J Exp Med 188:791-795.

Williams RT, Manji SS, Parker NJ, Hancock MS, Van Stekelenburg L, Eid JP, Senior PV, Kazenwadel JS, Shandala T, Saint R, Smith PJ, Dziadek MA. (2001). Identification and characterization of the STIM (stromal interaction molecule) gene family: coding for a novel class of transmembrane proteins. Biochem J 357: 673-85.

Winding P, Berchtold MW. (2001). The chicken B cell line DT40: a novel tool for gene disruption experiments. J Immunol Methods 249: 1-16. 
Xu S, Tan JE, Wong EP, Manickam A, Ponniah S, Lam KP. (2000). B cell development and activation defects resulting in xid-like immunodeficiency in BLNK/SLP-65deficient mice. Int Immunol 12: 397-404.

Xu, Y., K.W. Harder, N.D. Huntington, M.L. Hibbs, and D.M. Tarlinton. (2005). Lyn tyrosine kinase: accentuating the positive and the negative. Immunity 22:9-18.

Yamanashi, Y., and D. Baltimore. (1997). Identification of the Abl- and rasGAPassociated $62 \mathrm{kDa}$ protein as a docking protein, Dok. Cell 88:205-211.

Yamanashi, Y., T. Kakiuchi, J. Mizuguchi, T. Yamamoto, and K. Toyoshima. (1991). Association of B cell antigen receptor with protein tyrosine kinase Lyn. Science 251:192-194.

Yamanashi Y, Tamura T, Kanamori T, Yamane H, Nariuchi H, Yamamoto T, Baltimore D. (2000). Role of the rasGAP-associated docking protein p62(dok) in negative regulation of B cell receptor-mediated signaling. Genes Dev 14: 11-6.

Yamauchi, K., V. Ribon, A.R. Saltiel, and J.E. Pessin. (1995). Identification of the major SHPTP2-binding protein that is tyrosine-phosphorylated in response to insulin. $J$ Biol Chem 270:17716-17722.

Yasuda, T., K. Bundo, A. Hino, K. Honda, A. Inoue, M. Shirakata, M. Osawa, T. Tamura, H. Nariuchi, H. Oda, T. Yamamoto, and Y. Yamanashi. (2007). Dok-1 and Dok-2 are negative regulators of $\mathrm{T}$ cell receptor signaling. Int Immunol 19:487-495.

Yasuda T, Maeda A, Kurosaki M, Tezuka T, Hironaka K, Yamamoto T, Kurosaki T. (2000). Cbl suppresses B cell receptor-mediated phospholipase C (PLC)-gamma2 activation by regulating B cell linker protein-PLC-gamma2 binding. $J$ Exp Med 191: 641-50.

Yasuda, T., M. Shirakata, A. Iwama, A. Ishii, Y. Ebihara, M. Osawa, K. Honda, H. Shinohara, K. Sudo, K. Tsuji, H. Nakauchi, Y. Iwakura, H. Hirai, H. Oda, T. Yamamoto, and Y. Yamanashi. (2004). Role of Dok-1 and Dok-2 in myeloid homeostasis and suppression of leukemia. J Exp Med 200:1681-1687.

Ye, Z.S., and D. Baltimore. (1994). Binding of Vav to Grb2 through dimerization of Src homology 3 domains. Proc Natl Acad Sci U S A 91:12629-12633.

Zhao, M., A.A. Schmitz, Y. Qin, A. Di Cristofano, P.P. Pandolfi, and L. Van Aelst. (2001). Phosphoinositide 3-kinase-dependent membrane recruitment of p62(dok) is essential for its negative effect on mitogen-activated protein (MAP) kinase activation. $J$ Exp Med 194:265-274. 


\section{Curriculum Vitae}

Marion Lösing

born $27^{\text {th }}$ June 1983 in Vreden, Germany

Reinholdstrasse 12, 37083 Göttingen, Germany

E-Mail: marionloesing@web.de

Education and Research Experience

2007-present University Medicine Göttingen, Germany, Department of Cellular and Molecular Immunology, PhD thesis: Studies on adaptor proteins that shape antigen receptor-proximal signal transduction in B lymphocytes

2007-present Georg-August University Göttingen, Germany, International PhD Molecular Medicine program (Direct admission to $\mathrm{PhD}$ )

2006- 2007

University Medicine Göttingen, Germany, Department of Cellular and Molecular Immunology: Diploma Thesis

2002-2007

Georg-August University Göttingen, Diploma studies in Biology

2002

Gymnasium Georgianum, Vreden, Germany, Abitur (A-Level)

Prizes:

2010

Poster Prize at the 'Spring School on Immunology' 